\title{
V.7.
}

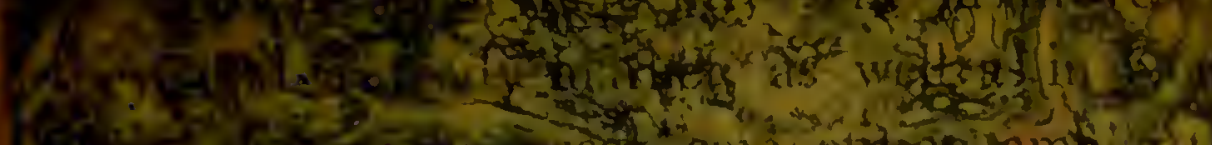

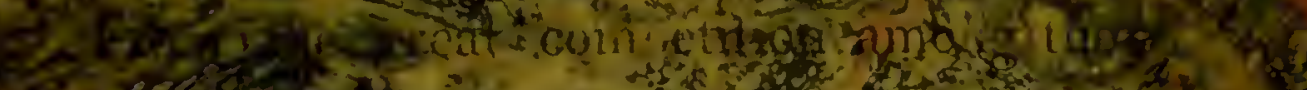

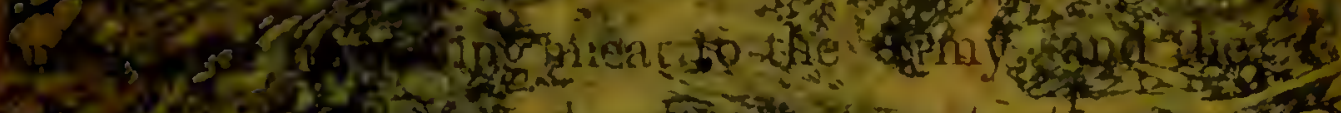

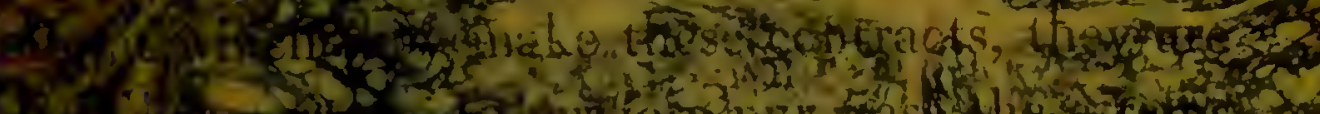

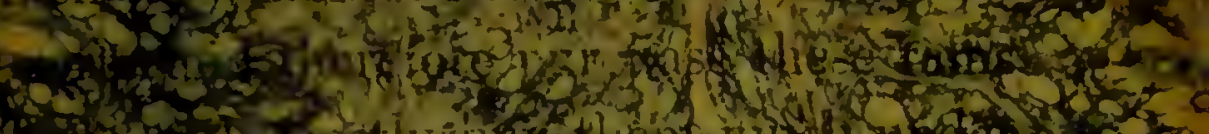

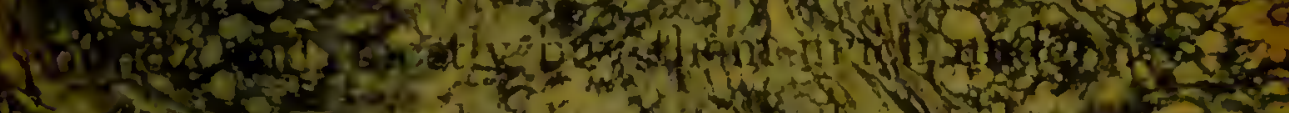
tof

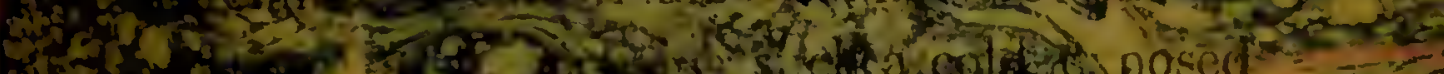

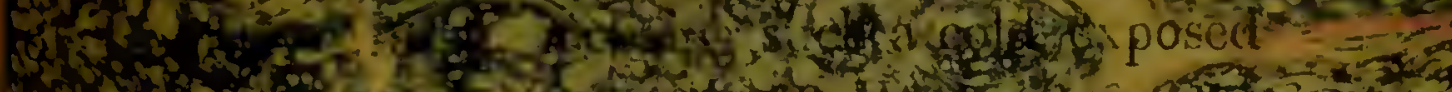

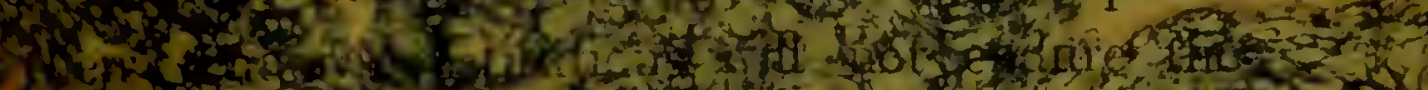

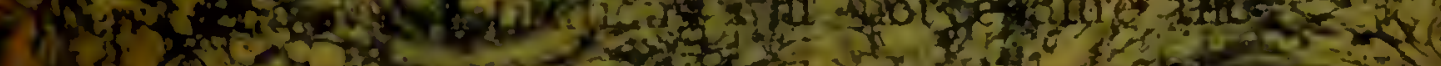

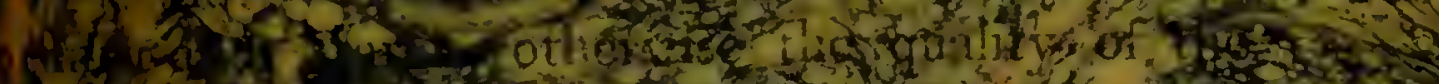

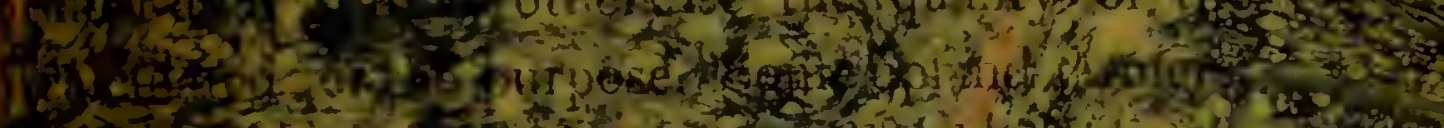

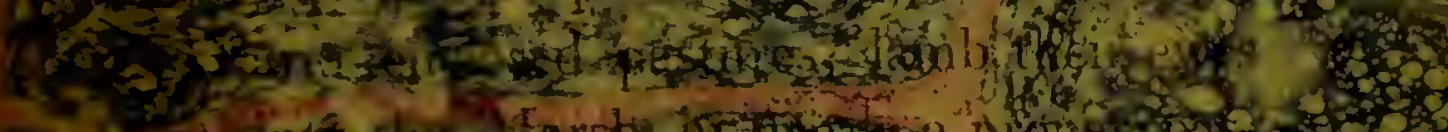

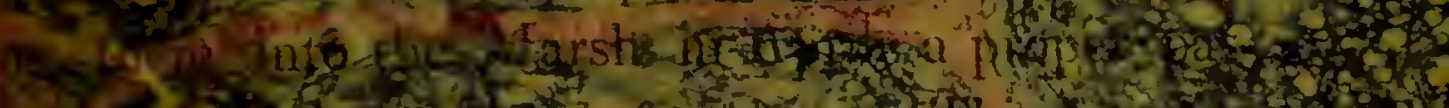

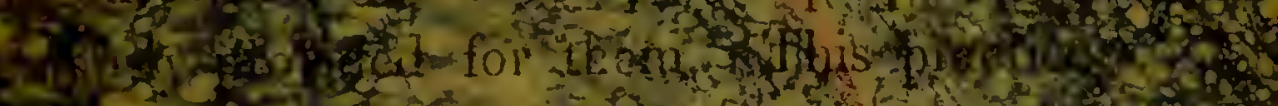

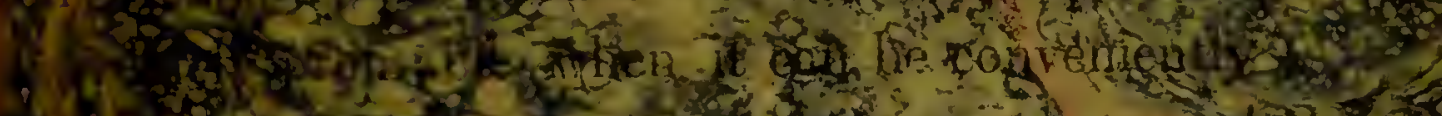
of 1 -

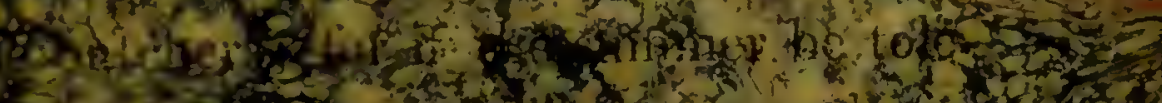

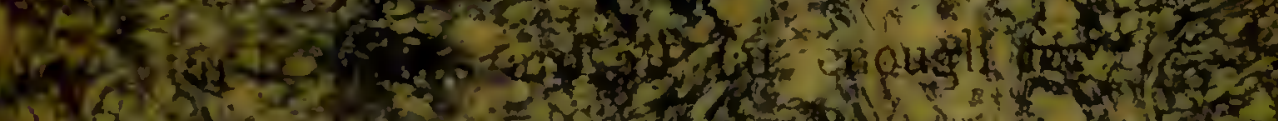

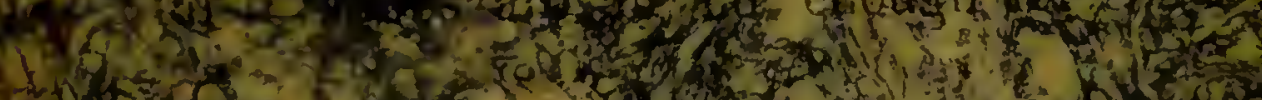

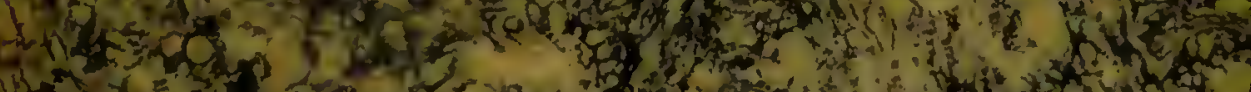
H.

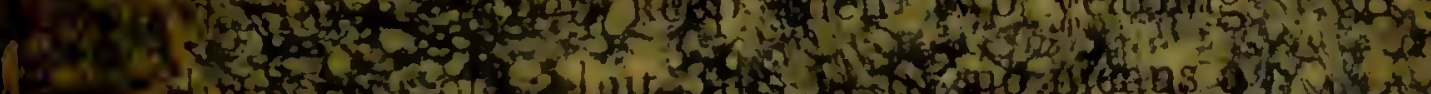

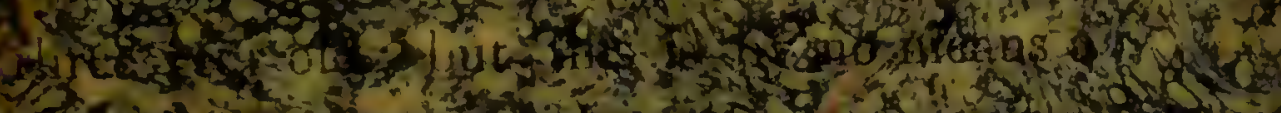

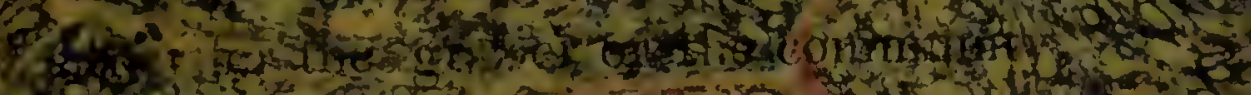

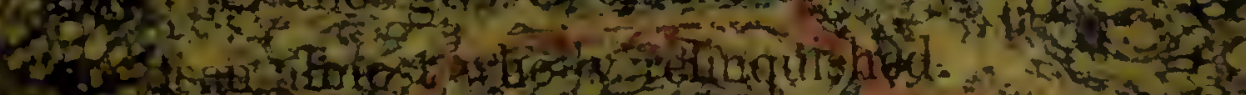
Wol col

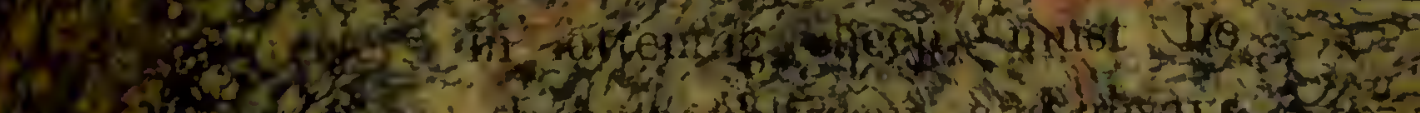

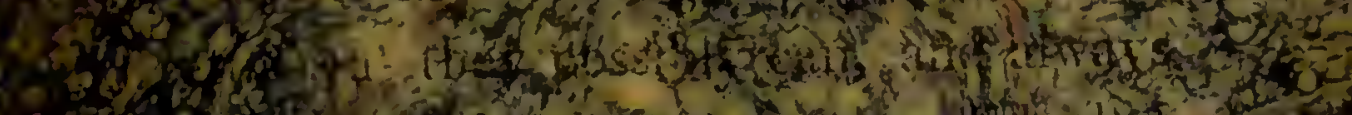
250.7.

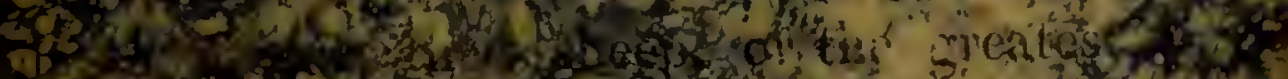

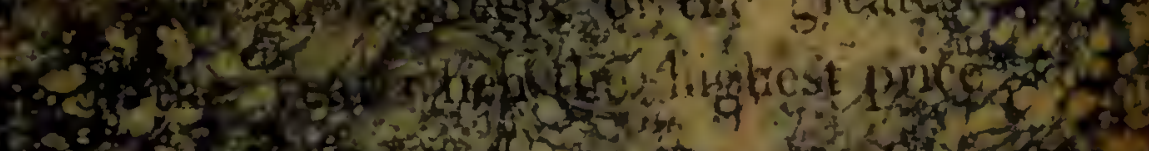

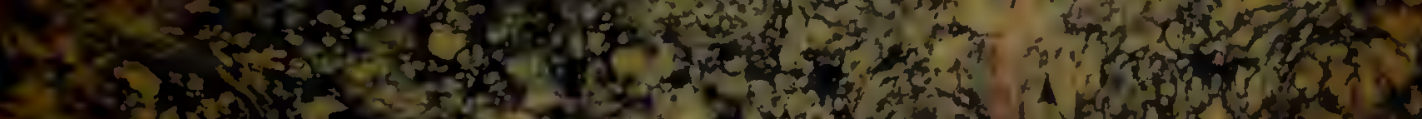

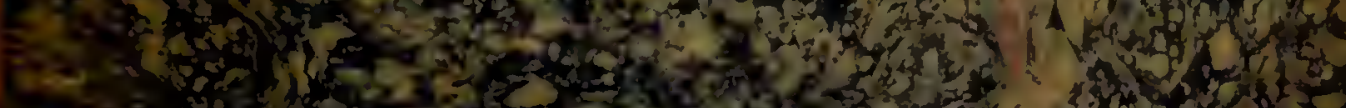

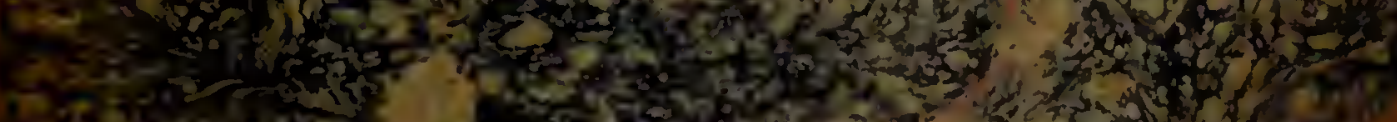

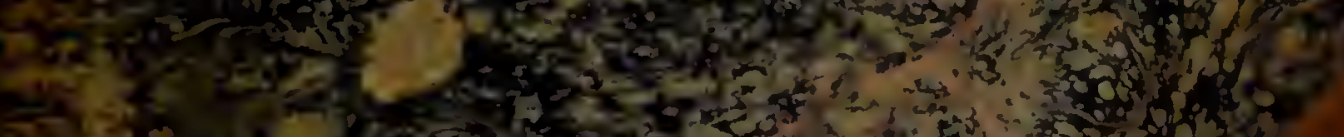




$$
219
$$




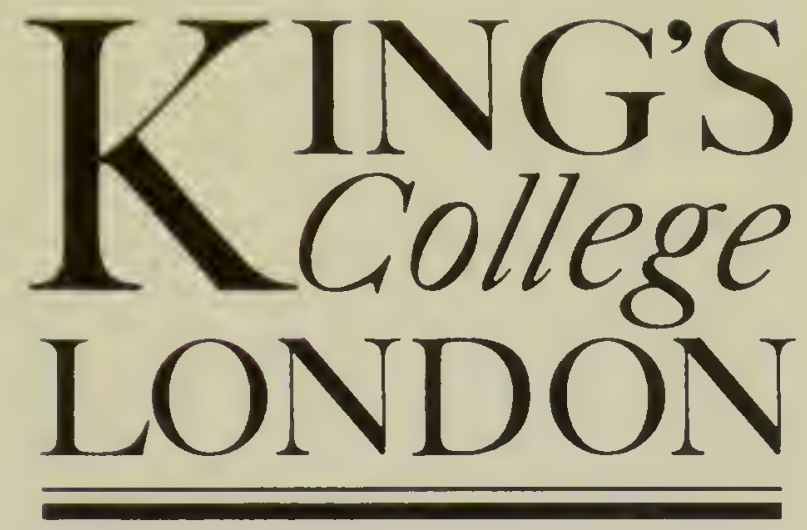

Linné Library

Leichesis keppenine, or, it oure..

1811

GHPS OL971. L2 LIN

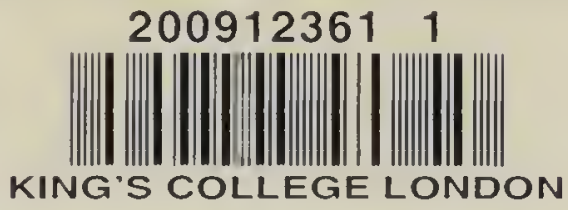




\{tomeng $\times 41: A, B$

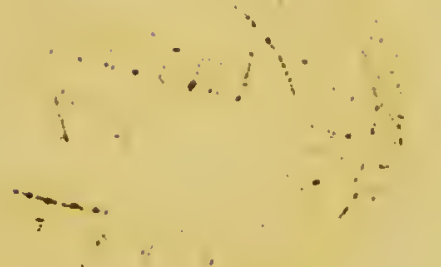




\section{Lachesis Lapponica,}

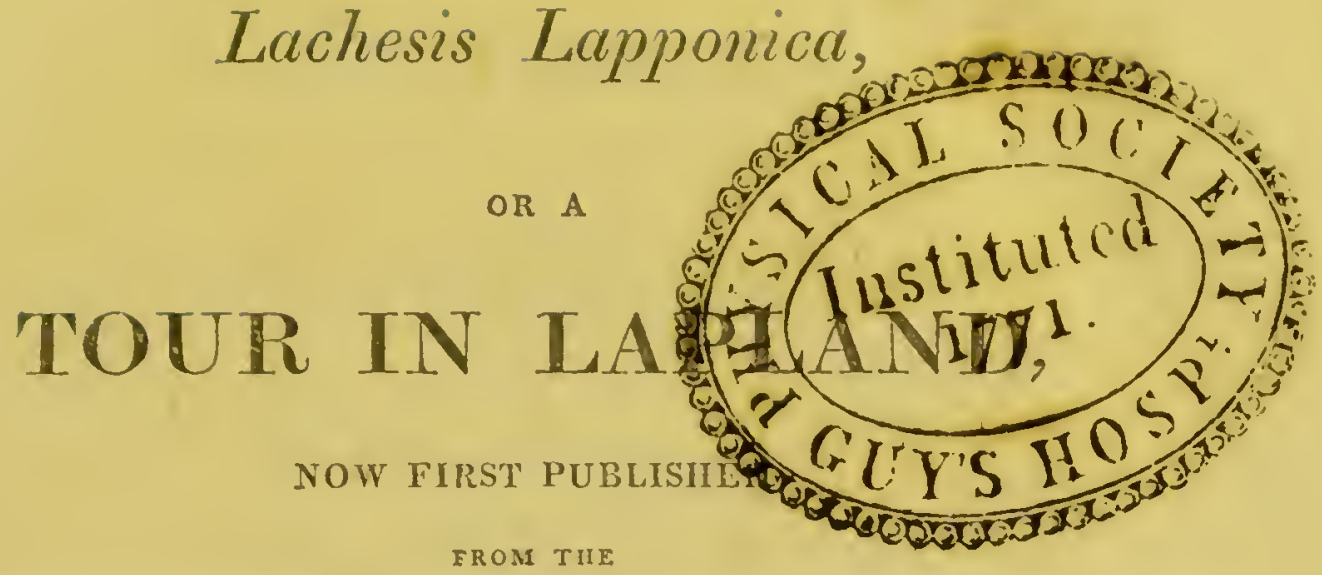

ORIGINAL MANUSCRIPT JOURNAL

UF THE CELEBRATED

\section{I N N $\mathbb{E}$ U S}

BY

JAMES EDWARD SMITH, M. D. F.R.S. ETC. PRESIDENT OF THE LINNEAN SOCIETY.

IN TWO VOLUMES.

VOL. II.

"Ulterius nihil est, nisi non habitabile frigus."

Ovin.

\section{LONDON:}

PRINTED FOR WHTE AND COCHRANE, HORACE'S HEAD,

FLEET-STREET,

BY RICHARD TATLOR AND CO, SHOE-LANE.

1811. 


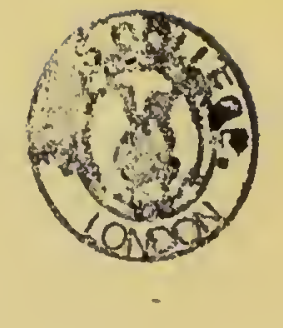




\section{JOURNEY}

\section{TO \\ LAPLA N D.}

$I_{N}$ the latter part of this day, July 15 th, I set out on my return from the low grounds of Norway. The heat was very powerful as we began to ascend the mountains. When we reached what had seemed to us from below the summit of a hill, we saw just as lofty an eminence before us, and this was the case nine or ten successive times. I had no idea of such mountains before. The elevation of this hill cannot be taken by any geometrical instrument, as the summit is not visible, even at some miles' distance. I believe its height must exceed a Swedish mile, but to climb it was worse than going two miles any other way. VOX. II. 
Had we not frequently met with such abundance of water, we should have been overcome with fatigue. In this ascent I found the little Astragalus (alpinus) with a white flower, and the Little Gentian (Gentiana nivalis).

Our clothes, which were wot quite through with perspiration, in consequence of the heat we had encountered in the beginning of our journey, were now frozen stiff upon our backs by the cold. We determined to seek for a Laplander's hut. In order to get at one, we were obliged to descend so steep a hill, that, being unable to walk down it, I lay down on my back and slid along, with the rapidity of an arrow from a bow. I aroided with difficulty the large snow torrents that every now and then came in my way, and which were sometimes within an ell of me.

On reaching this hut, I noticed some of the reindeer whose horns were not above half an inch long, the Brom-fly (Oestrus Tarandi) haring bitten them while quite 
tender; for these insects are, in the Norwegian alps, worse than the gnats of Swedish Lapland.

I here obtained a curious piece of information respecting the mode of castrating the reindeer. When the animal is two years and a half old, its owner, about a fortnight before Michaelmas, getting a person to assist him by holding it fast by the horns, places himself betwixt its hind legs. He then applies his teeth to the scrotum, so as to bruise its contents, but not so as to break the skin, for in that case the reindeer would die: He afterwards bruises the part still more effectually between his fingers. The same operation is performed on both sides, if the reindeer remains quiet long enough for the purpose at one time. The animal is in consequence rather indisposed for a while, so that he can hardly keep up with the rest of the herd, but he usually recovers perfectly in a week's time. 'This is certainly an art no less curious than remarkable, and merits further consideration. 
The girls here, especially when they wish to appear to advantage, divide their hair into two braids, one above each ear, which braids are tied together, at the hind part of the head, so as to hang down the back. A tuft of ribands is appended to the extremity of each braid.

\section{July 16.}

We undertook to cross the ice-mountain. Having proceeded some way on our journey, we observed a dense cloud to the northeast. It was visible both above and below us, and at length approached us in the form of a thick mist, which moistened our clothes, and rendered even our hair thoroughly wet. It so completely obliterated our horizon, that we could neither see sun nor moon, nor the summits of the neighbouring hills. We knew not whither to turn our steps, fearing on the one hand to fall down a precipice and lose our lives, as actually happened, a few years ago, to a Laplander under the same circumstances; or on the 
other to be plunged into the alpine torrent, which had worn so deep a channel through the snow, as to make any one giddy, looking upon it from above. We could now not distinguish any thing a couple of ells before us. Our situation was like that of an unskilful mariner at sea without a compass, out of sight of land, and surrounded by hidden rocks on every side. The Laplanders themselves consider the situation we were in as one of the worst accidents that can ever befall them. We, however, though destitute of a guide, were fortunate enough to discover the track of a reindeer, and of some kind of carriage in which goods had probably been lately conveyed towards Norway. This track directed us safely to one of the Lapland moveable tents.

All the Laplanders are usually bleareyed, so that one would think the word Lappi (Laplanders) was derived from lippi (blear-eyed). The causes of this inconvenience are various, but chiefly the following. 
1. The sharp winds. In the early part of my journey, repeated exposure to stormy weather rendered my eyes sore, so that I became unable to open them wide, and was obliged to keep them half shut. How much more must this be the case with those who dwell on the alps, where there is a perpetual wind!

2. The snow, the whiteness of which, when the sun shone upon it, was very troublesome to me. To this the alpine Laplanders are continually exposed.

3. The fogs. This day I found myself very comfortable in my walk over the icy mountain, till the fog, mist, or cloud, whichever it might be called, came about me, rendering the eyes of my interpreter, as well as my own, so weak and relaxed, that we could not open them wide without an effort. Such must often be the case with the Laplanders.

4. Smoke. How is it possible that these people should not be blear-eyed, when they are so continually shut up in their huts, 
where the smoke has no outlet but by the hole in the roof, and consequently fills every body's eyes as it passes!

5 . The severity of the cold in this country must also contribute to the same inconvenience.

The mountain Laplanders, or those who live in the alps, build no huts; they have only tents made in the following manner.

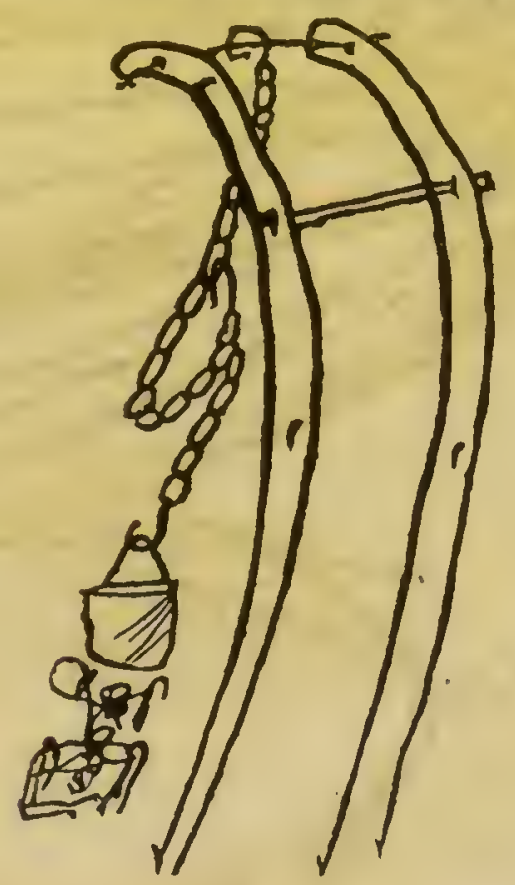

The first figure represents two connected 
beams, which compose the frame-work of one side of the hut; and these meet at the

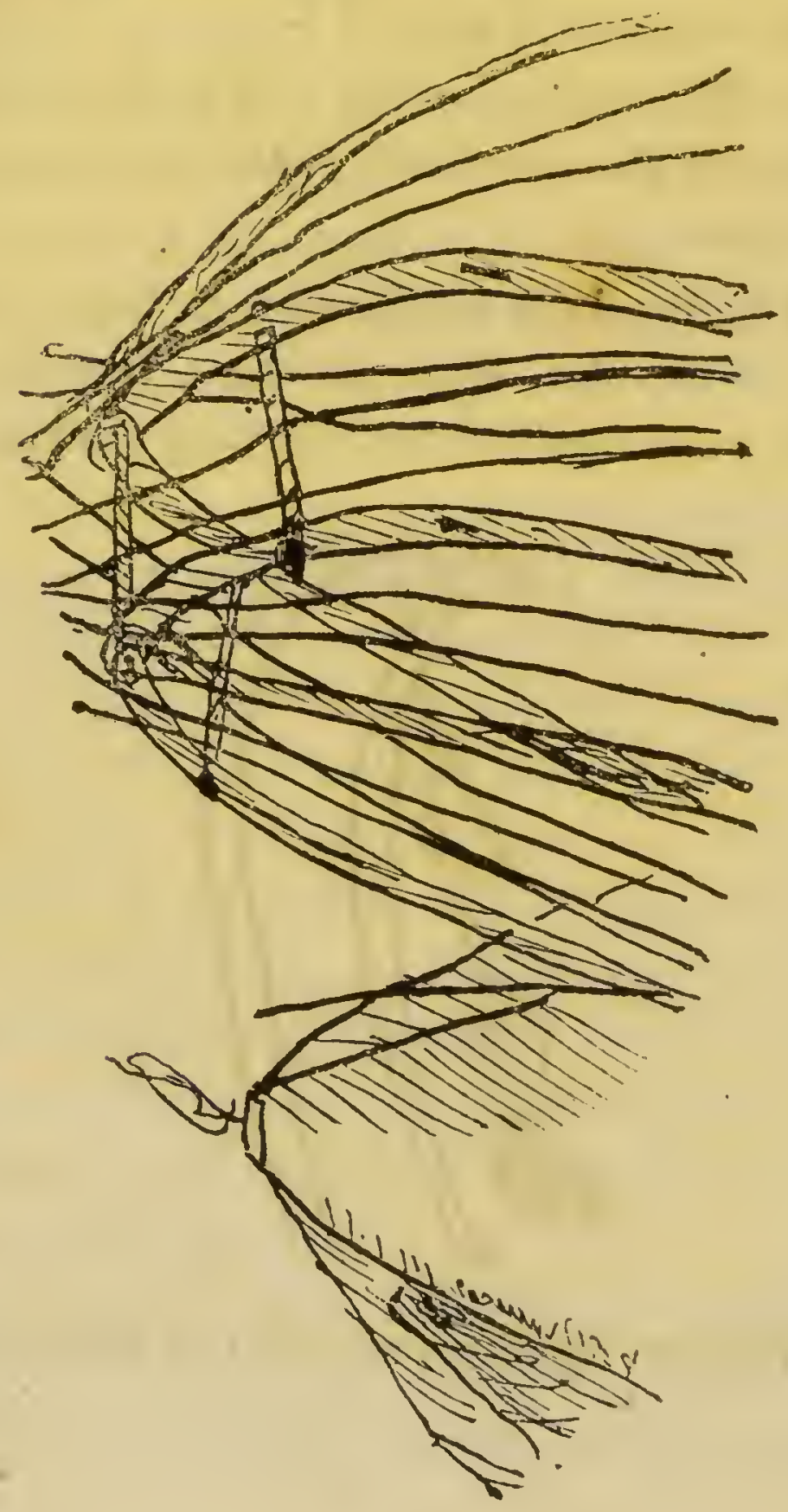


top with two similar ones, forming the opposite side. A solitary beam is placed on each side, in the middle of the arch formed by these four, so that the whole edifice has six angles. Two more slender sticks, but equally tall, are then erected between every two angles, or main ribs, of the building. Over the whole is spread the corering of the tent (made of walmal clothi). The usual height of the structure is about a fathom and half, and the breadth two fathoms. A flap of cloth is left, so as to open and shut by way of a door, between two of the main beams.

When they lie down to rest, and are fearful of being incommoded by heat, they fix a hook through the middle of the coverlet, which raises it perhaps an ell and a half above them, and under this canopy they repose.

The women wear several things attached to their belt, as a leather bag, fig. 1, containing a spoon, as well as a pipe. fig. 3. 
Fig. 2. A knife in a case.

4. A thimble made of leather, which goes round the finger.

5. A pin-cushion, with a brass cover which pulls down over it like a cap.

6. Several large brass rings.

The belt itself is ornamented with tin or silver embroidery, and pearls.

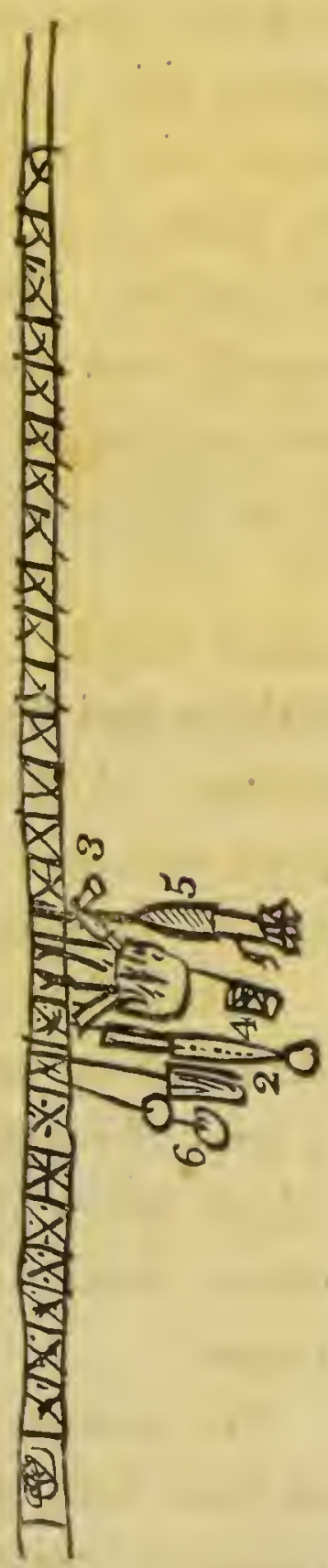


The men wear, instead of the above, a kind of bag, hanging down exactly in front. This is divided internally into two pockets, containing their tobaccopipe, tinder-box, tobacco, and a spoon made of reindeer's horn, of an oblong flattish shape.

The women often wear a similar bag, but of a smaller size.

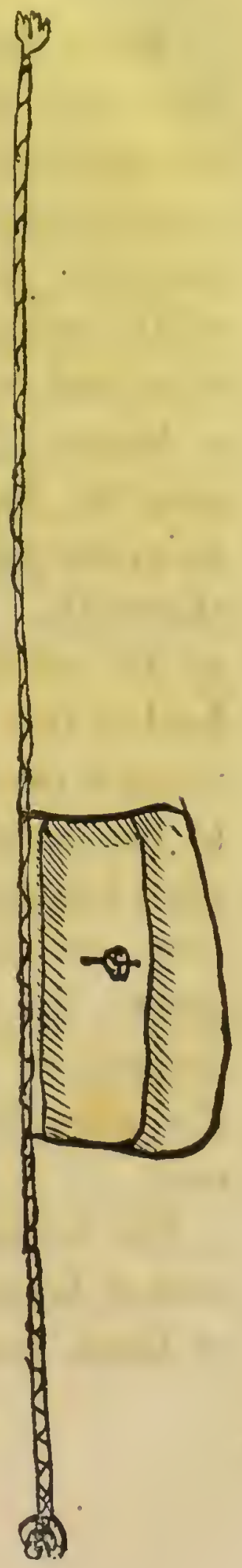


When the reindeer are milked, as they cast thcir coat during the whole course of the summer, the hair flies about very inconveniently, often covering the milk in the pail. Some hair sticks also to the dugs of the animal, and it is found necessary to clean and soften them before the milling is begun. This is generally done by dipping the fingers into the milk which may be in the pail already, and washing them therewith. Whenever it happens that one of the reindeer strays from its master's herd to that of a neighbour, the person to whom it comes mills it, without any offence to the proper owner. Such an accident often happens; for these animals love society, and the more of them there are together, the better they thrive and enjoy themselves. They are marked at the ears, like cows, that every person may know his own.

The furniture of these Laplander's consists of kettles and pots, made sometimes of brass, sometimes of copper; rarely of 
stone, on account of the weight. They have also hemispherical bowls, with handles, generally made of the hard knotty excrescences of the birch. These are often large enough to hold four or five cans, (of three quarts each,) and formed so neatly, that any one would believe them to be turned. Into these they pour what is to be served up at their meals. Plates they have none, but in their stead boards, of an oblong shape, are used for meat; which, previous to its distribution among the guests, is served up in round pails. Closely platted baskets, or tubs, always circular, are used to keep cheese in. There is moreover an oblong barrel, for the purpose of holding jumomjolk (vol. 1. p. 273).

Within the tent are spread on each side skins of reindeer, with the hairy part uppermost, on which the people either sit or lie down, for the tent is not lofty enough to allow any one to stand upright. In the centre of the whole is the fire-place, or a square enclosure of low stones about the 
ash-heap. The back part of the tent, behind the fire-place, is entirely occupied either with brush-wood or branches of trees, behind which, or, most commonly, before it next the fire, the household furniture is placed. In the roof are two racks, suspended over the reindeer skins on each side, upon which cheeses are laid to dry, and before these, towards the entrance, hang rennet-bags, filled with milk, preserved for winter use.

The annexed figure is a sort of plan of the floor of one of these Lapland tents: $a$ is the fire-place. $b, b$, reindeer skins, six in number, three at the right hand, on entering the tent, and as many at the left. c large fire-iwood. d cheese-ressels. e kettle, with its lid. f, behind the first reindeer skin, is the place of the harness. $g$. a barrel or cask. h a store of skins and hair of the reindeer. i the mill-strainer, with its flat corer. 


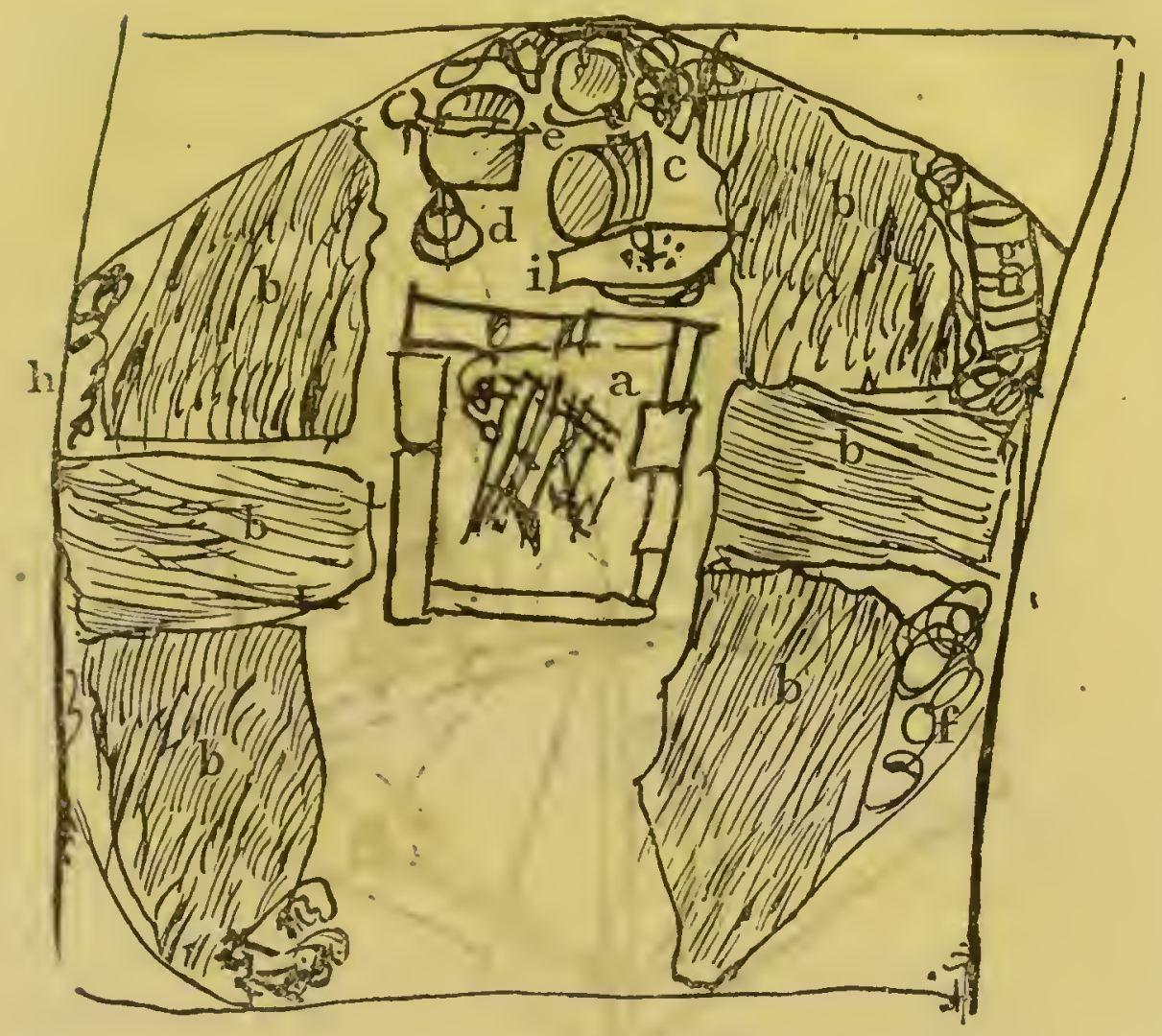

The following figure represents the roof' of the tent, as seen from below. a, a, are the racks on which the cheeses are ranged. b outlet for the smoke. c, c, rennet-bags containing milk. d plat of hair from the reindeer's tail, to strain milk through. e the flat cover of the milk-strainer; see $i$ in the former figure. 


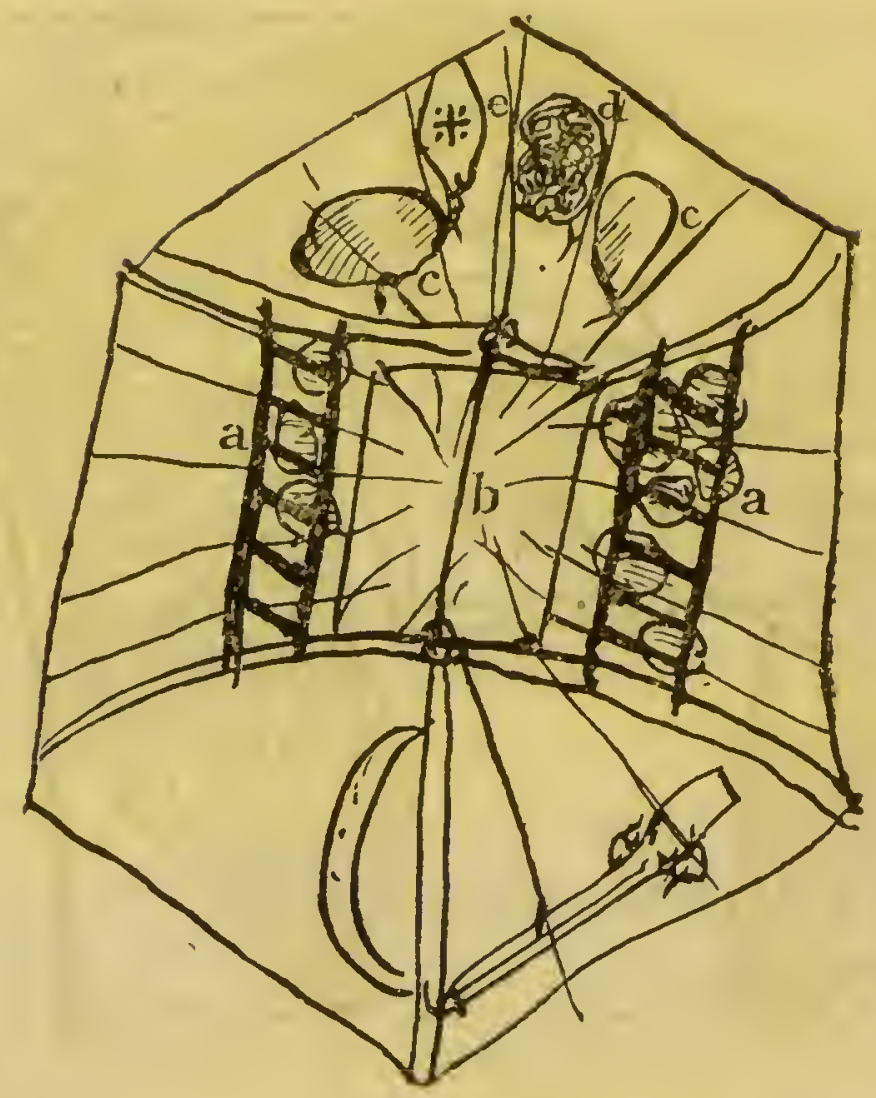

Such was the dwelling, and I shall now describe some of its inhabitants. I sat myself down at the right hand of the entrance, with my legs across. Opposite to me sat an old woman, with one leg bent, the other straight. Her dress came no lower than her knees, but she had a belt embroidered with silver. Her grey hair hung straight down, and she had a wrinkled 
face, with blear eyes. Her countenance was altogether of the Lapland cast. Her fingers were scraggy and withered. **** Next to her sat her husband, a young man, sixand-thirty years of age, who, for the sake of her large herds of reindeer, had already been married ten years to this old hag. When the Laplanders sit, they either cross their legs under them, or one knee is bent, the other straight.

As a defence against wind and snow, a sort of hood, called nialmiphata, is worn over the cap. It is made of red cloth, of the shape of a truncated cone, dilated at the bottom, and is four palms high, three palms in circumference at the upper part, and six at the bottom. This covers the cheeks, as well as the neck and shoulders, the eyes and mouth only being exposed. In the back part, at bottom, is a loop, through which goes a riband to secure the whole from being blown off, by being tied round the body under the arms.

In winter-time the women wear breeches, made exactly like those worn by the men, VOI. II. 
as well as boots, though the latter come no higher than the knees. It is wonderful how they are able, in the severity of winter, to follow the reindeer, which are never at rest, but keep feeding by night as well as by day. They have indeed small sheds or huts, here and there, into which they occasionally drive their reindeer, but with the greatest difficulty.

During the night we passed over the beautiful lake of IVirisiur. The weather was very cold and foggy.

$$
\text { July } 17 .
$$

In the morning we arrived at the abode of Mr. Kock, the under bailiff, where I could not but admire the fairness of the bodies of these dark-faced people, which rivalled that of any lady whatever.

Here I saw some Leming Rats, called in Lapland Lummick. The body of these animals is grey; face and shoulders black; the loins blackish; tail, as well as ears, very short. They feed on grass and reindeer-moss (Lichen rangiferinus), and are 
not eatable. They live, for the most part, in the alps; but in some years thousands of them come down into the woodland countries, passing right over lakes, bogs, and marshes, by which great numbers perish. They are by no means timid, but look out, from their holes, at passengers, like a dog. They bring forth five or six at a birth. Their burrows are about half a quarter (of an ell ?) deep.

Here I found the little Gentian, or Centaury, with a hyacinthine flower in five notched segments (Gentiana nivalis).

\section{July 18.}

I gathered and examined the little Catchfly, which resembles the common one (Lychnis Viscaria) except in being smaller, and not at all viscid. ( $L$. alpina; see v. 1. p. 302.n. 46.) The root is perennial. Leaves oblong-lanceolate, approaching to linear. Stem simple, round, smooth, bearing two, three, or four pairs of opposite leaves. From the uppermost pair springs 
one flower-stalk on each side, bearing a single flower, between two small opposite purple leares. A little higher up, two other simple flower-stalks come forth in the same manner, with two coloured leares at their base, the stem being thus cxtended straight upwards. Calyx ovate, erect, coloured, with five teeth. Petals five, their disk cloven half way down; the crown with two teeth. Stamens 10. Pistils 5.

After passing the alps, we grew thirsty ; but the water we met with proved less pleasant than usual, having an earthy taste, although it flowed from plentiful stores of ice and snow. My Laplander took his knife and cut out a lump of ice, which he sucked by way of refreshment. I found this mode of drinking agreeable enough, the ice being very palatable, and we both partook of it largely. He told me it was considered very wholesome for the chest. Indeed I learned, both from the Laplanders and my own experience, that pure water, however cold, is never hurtful, provided it be taken in moderation. 
I was desirous of having my linen washed; but the people understood my request as little as if I had spoken Hebrew, not a single article of their own apparel being made of linen. As their food is of animal origin, so is their clothing, which consists either of skins, the produce of the country, or of the woollen cloth called walmal, which they purchase. In the winter they wear Lapland boots, which come up as high as the middle of the thighs, without any stockings, only the feet are protected with what they term Skogras (Carex sylvatica Fl. Brit.), as already mentioned. Next to the body they wear a jacket of walmal, and above that a lappmudd, or coat of reindeer skin, with the hairy side turned inwards. In summer they turn that side outwards. The boots used by the women do not reach higher than the linee.

$$
\text { July } 19 .
$$

I remarked with astonishment how great- 
ly the reindeer are incommoded in hot weather, insomuch that they cannot stand still a minute, no not a moment, without changing their posture, starting, puffing and blowing continually, and all on account of a little fly. Even though amongst a herd of perhaps five hundred reindeer there were not above ten of these flies, every one of the herd trembled and kept pushing its neighbour about. The fly meanwhile was trying every means to get at them; but it no sooner touched any part of their bodies, than they made an immediate effort to shake it off. In one respect this season is peculiarly propitious to the insect, as the reindeer's coat is now very thin, most of the hair of last year's growth being fallen off. I caught one of these insects as it was flying along with its tail protruded, which had at its extremity a small linear orifice, perfectly white. The tail itself consisted of four or five tubular joints, slipping into each other, like a pocket spying-glass, which this fly, like others, has a power of contract- 
ing at pleasure. See what I have already mentioned (vol. 1. p. 280), concerning the spots in the reindeer skins, as caused by this insect (Oestrus Tarandi).

When the Lapland children are laid into the cradle, they seldom cry, although their hands are confined down to their sides. If they cry, it is generally from hunger. The cradle is placed in a sloping position, so that the child's head is half upright. The bottom of the cradle is hollowed out of a piece of fir wood, consequently not very heavy. Over the head of the child is a hoop forming an arch, to which a transverse bow is fixed, the whole being covered with cloth, like the rest of the cradle. In summer the child lies without any covering of reindeer hair, only having under its head and body either some walmal cloth, fur, or moss.

The Laplanders use a curious kind of box or basket, which they call kisa, for keeping or carrying various articles. It is of an oval form, with the bottom and sides 
macle of fir, like a box, being about a foot and half long, a foot broad, and six inches deep, with a transverse opening in the bottom to admit a part of the saddle of the reindeer. The contents are confined by a lacing of cords, that goes from side to side across the top, which is otherwise open. 'Two such boxes, each weighing about two pounds, are placed like panniers upon the reindeer; for that animal cannot carry above four or five pounds weight, and the castrated males only are used as beasts of burthen at all. A leather thong crosses the saddle, connected with another longer one, which goes round the chest of the animal at one part, and round its thighs, like the breechings of a horse, at the other. A pack-saddle, made either of reindeer skin, or of walmal cloth, with a bow of spruce fir, goes across the back, and is connected with the leather thongs just mentioned, being further secured by a girth under the belly. Against the sides of this pack-saddle the above-described boxes or 
baskets are hung and fastened, the transrerse chink in the bottom of each being fitted to the saddle.

I observed that the Laplanders, both men and women, after borrowing a lighted pipe, and passing it from one to another, retain a mouthful of smoke as long as possible, that they may enjoy as much of the flavour as they can. Old men chew tobacco.

The tendons in the legs of the reindeer scrve to make thread or cord. In each hind leg are two tendons, one before the other; in each fore leg one behind and two or three before it. These the Laplanders lay hold of with their mouths, split and moisten them, rubbing them from time to time with reindeer marrow, preserved in bladders for that use, in order to render them as supple as possible. Each string is made sharp at both ends, and drawn through holes of various sizes in an instrument made on purpose (of wood or metal) to render it as fine and smooth as they can. Two such threads 
are then twisted together by means of the hand upon the thigh or knee. They are generally held with the left hand, and twisted with the right upon the left knee, proceeding downwards, the thread being moistened from time to time with saliva.

In this part of the country the Empetrum (Crow- or Crake-berry) serves for firing. Otherwise the most common fuel is the dwarf Birch (Betula nuna), and the Willow with lanceolate white hairy leaves (Salix lapponum), so very abundant on the Lapland alps. The dwarf birch bears very small leares in these elevated regions.

When the children are taken out of the cradle, which I have already described (vol.2.p.23), they are dressed in a small garment of reindeer skin. They are usually able to stand on their legs by the time they are four months old, and turn their head and eyes about with a degree of intelligence hardly ever seen in our children at that early age.

I never met with any people who lead 
such easy happy lives as the Laplanders. In summer they make two meals of milk in the course of the day, and when they have gone through their allotted task of milking their reindeer, or making cheese, they resign themselves to indolent tranquillity, not knowing what to do next. In winter their food is cheese, taken once or twice a day, but in the evening they eat meat. A single reindeer supplies four persons with food for a week.

This animal has no gall-bladder, nor could I discover the insertion of the biliary duct. The liver however is of a large size. The first stomach is large, with a thick orifice, and lined with a fine cellular network like that of a cow, being moreover longitudinally plaited. The Laplanders are curious dissectors. They take out each of the stomachs separately, with as much care as a professed anatomist.

The thread made of sinews, as above described, is never used for sewing walmal, which makes their summer clothing, but only for garments composed of fur or lea- 
ther. Their shoes indeed are mended, as well as made, with it. This last business falls to the lot of the women. The leather is purchased.

A good ox may be bought in Norway for three rix-dollars; a female reindeer for one rix-dollar; a castrated male for from twelve to eighteen dollars, silver coin; and a fawn is worth from twelve to eighteen dollars of copper money. Three reindeer, therefore, are but equal to the value of a common ox.

I left this place in the evening, proceeding on my journey on foot, and walking all night long, till three o'clock in the afternoon of the following day. Thus I walked six miles at a stretch, before I arrived at another Lapland hut.

Nothing occurred particularly worth noticing by the way, except an Andromeda (tetragona) with quadrangular shoots, and

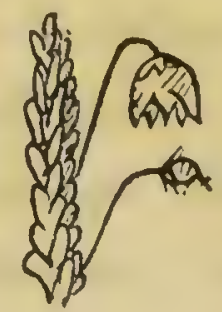


flowers from the bosoms of the leaves. The stem is woody, procumbent, naked, threadshaped, variously divided. Branches partly erect, entirely covered with leaves, which are oblong, obtuse, somewhat rounded, concare, keeled, sessile, disposed in an imbricated manner. Flower-stalks solitary, from the bosoms of the leaves, erect, threadshaped, whitish, each bearing a drooping flower. Calyx five-cleft, purplish, with ovate straight segments. Petal one, halfovate or bellshaped, exactly resembling the lily of the valley, cut half way down into five erect acute segments. Stamens ten, very short, with horned anthers, scarcely longer than the calyx. Pistil simple, the length of the calyx. Pericarp roundish, with five obtuse angles, erect, of five cells, with several seeds $*$

* The discovery of the plant in question is related in the Flora Lapponica in so interesting a manner, that we cannot refrain from translating the passage. See the second edition, p. 135.

"I met with this plant but once, and that through. 


\section{July 20.}

The people here use a kind of bread called Blodbrod (Blood Bread), made of small fiesh fish, bruised and mixed with a little quantity of flour. This is baked or roasted on a jack before the fire, but it is used only in hard times.

out a journey of four hours, over the celebrated mountain of Wallivari in the district of Lulea, towards a tract of country which lies about half way between the northern and western part, where it grew in great abundance.

"Whilst I was walking quickly along, in a profuse perspiration, facing the cold wind, at midnight; if I may call it night when the sun was shining without setting at all ; still anxiously inquiring of my interpreter how near we were to a Lapland dwelling, which I had for two hours been expecting, though I knew not its precise situation; casting my eager eyes around me in all directions, I perceived as it were the shadow of this plant, but did not stop to examine it, taking it for the Empetrum. But after going a few steps further, an idea of its being something I was unacquainted with came across my mind, and I turned back; when I should again have taken it for the $\mathbf{E m}$ petrum, had not its greater height caused me to consider it with more attention. I know not what it is 
There are no common flies, bugs, nor snakes, on these Alps.

The Laplanders however abound with lice, which in winter are allowed to freezc, when they turn red, and are easily killed. In summer they come forth from the clothes, if exposed to the sun, and are then de-

that so deceives the sight in our Alps during the night, as to render objects far less distinct than in the middle of the day, though the sun shines equally bright. The sun being near the horizon, spreads its rays in such a horizontal direction, that a hat can scarcely protect our eyes : besides, the shadows of plants are so infinitely extended, and so confounded with each other, from the tremulous agitation caused by the blustering wind, that objects very different in themselves are scarcely to be distinguished from each other. Having gathered one of these plants, I louked about and found several more in the neighbourhood, all on the north side, where they grew in plenty; but I never met with the same in any other place afterwards. As at this time they had lost their flowers, and were ripening seed, it was not till after I had sought for a very long time that $I$ met with a single flower, which was white, shaped like a lily of the valley, but with five sharper divisions." 
stroyed with the nails, these people having no firelock to shoot them with*

I was informed that in this neighbourhood the inoculated small-pox is remarkably fatal. If the patients have but seventy or eighty pustules, they die of it as of the plague. They fly to the mountains, when infected, and die. The same is the case with the measles. It appears that both these diseases are aggravated by the violent cold, whence the patients die in so miserable a manner $\uparrow$.

Swelled necks (goitres) are frequent.

Sore eyes are universal, especially in the spring, when the Laplanders remove towards the Alps. The glittering of the snow has then a pernicious effect on their eyes. Aged people are very often blind.

* This strange passage is presumed to allude to a little gun, four or five inches long, still shown in the arsenal at Stockholm, with which vulgar report says the famous Queen Christina used to kill fleas.

+ It is not impossible that Linnæus might be misled here by the prejudices of his time, or by those of the people from whom he obtained his account. 
Female obstructions are rare, though sometimes met with among the better sort of people; neither are the catamenia immoderate, nor in common so copious as with us. The Lapland women are entirely ignorant of the leucorrhou.

Of hysterics I met with but two cases. One maid-servant, twenty-four years of age, had the complaint about once a year; another, about thirty, was attacked with it monthly during the summer.

Epilepsy sometimes occurs. Headachs are frequent; hence the forehead is often seen full of scars (from the application of their toule, or moxa; see vol.1.p.274).

Elderly people are often hard of hearing.

The sleep of the Laplanders is commonly sound, and they are in the habit of sleeping or waking whenever they please.

A swelling, or falling down, of the uvula is not uncommon, in which case they frequently cut off the part affected.

When children are troubled with swellings in the glands about the throat, the VOL. II.

D 
usual remedy is to prick the part, and suck out the blood, which is considered as a speedy and effectual cure. If this method be not adopted, they suppose the blood would rise to the head, and cause cutaneous eruptions there.

Coughs are of very rare occurrence, notwithstanding the constant practice of drinking snow- and ice-water, even after swallowing pure grease or fat, which perhaps may prevent its bad consequences. However this may be, the Laplanders seldom die from catching cold. Cases of phthisis, or consumption, do indeed now and then occur among them, and pleurisies are very common, especially in spring and autumn. Lumbago, or pain in the back, is most prevalent during the summer. For this, as I have already mentioned, vol. 1. p. 274, actual cautery, by means of their toule, or moxa, is often applied.

Bleeding at the nose chiefly happens among those Lapland women who are in the service of the colonists, and who, in 
consequence of certain obstructions, are subject also to wedematous swellings of the feet.

I have not heard of a single instance of jaundice.

Some elderly people are afflicted with asthma; and hoarsenesses now and then occur in the winter and spring.

The stone and gout are entirely unknown amongst the Laplanders.

Swellings of the lower extremities are uncornmon, as these people are in the habit of swathing their legs, which renders them all slender and well shaped. All dropsical complaints indeed are very rare, though I did meet with one case of this kind.

Of tenesmus I happened to hear of but a single instance, though the Laplanders eat so much cheese and drink water.

Disorders in the stomach are not uncommon, which are frequently attended with diarrhoa, and in some years this disease is contagious.

The specimens of minerals which I had

1) 2 
collected in the course of my tour were now become numerous, and consisted of the following articles.

1. An alum, as I presume, of a club shape, without any taste, seeming as it were dissolved in fluor, from the mountains to the north of the lake Skalk, near Kiomitis. (See vol. 1.p. 267.)

2. Native alum in its own matrix; from the same place. (Alumen nativum. Syst. Nat. vol.3. 101).

3. Native alum, rough and green, separate from its matrix ; from the same mountains.

4. Alum like the former in appearance, but not salt, perhaps a calcareous stone; found not far from the same place.

5. Various alpine micaceous stones.

6. Marle from Lapland.

7. Quartz from Lapland.

8. Silver ore from Kiurivari.

9. Silver ore from Nasaphiel in Pithœan Lapland.

10. Sandstone containing three per cent. of iron. 
11. Black slate from the alps.

12. Petrified corals from Norway.

13. Iridescent fluors from the alps.

The fish called by the Laplanders Sijk (the Gwiniad, or Salmo Lavaretus, is taken in their lakes. Its head terminates in an obtuse point. The upper jaw is the longest. Mouth without tceth. Iris of the eye silvery, with a blackish upper edge, and a black pupil. The whole body is silvery, blackish about the back, eleven inches long and two deep. Head two inches long at the sides; from the snout to the dorsal fin four inches and a half. The dorsal fin consists of thirteen rays, of which the first is by far the largest, and the last cloven or interrupted. The soft fat fin is in its proper place.

$$
\text { July } 21 .
$$

The following are the disorders or inconveniences to which the reindeer are subject.

When the frost is so intense as to form an impenetrable crust on the surface of the 
snow, so that the animal cannot break it with his feet, to get at the Lichen on which he fceds, he is frequently starved to death. This misfortune is as dreadful to the Laplanders as any public or national calamity elsewhere; for, when his reindeer are killed, he must himself either starre to death, beg for his livelihood, or turn thief.

The hoofs of the reindeer are not uncommonly affected with a swelling at the edge where they are attached to the skin, at which part they consequently become ulcerated, and are seldom healed. The creature thus grows lame, and cannot keep up with the herd.

These animals are sometimes attaclied with a vertigo, or giddiness in the head, which causes them to run round and round continually. 'The people assured me, that such of them as run according to the course of the sun may be expected to get the better of the disorder; but those which turn the contrary way, being supposed incurable, are immediately killed. The reco- 
very of the former is thought to be promoted by cutting their ears, so as to cause a great discharge of blood.

The Kurbma, or ulceration caused by the Gad-fly, (see vol. 1.p.280.) takes place every spring, especially in the younger fawns. Such as are brought forth in the summer season are free from this misfortune the ensuing spring, but in the following one many of them lose their lives by it. When come to their full size and strength, the consequences are less fatal; but no reindeer is entirely exempt from the attacks of this pernicious insect.

The fawns are of a reddish hue the first season, during which they cut their foreteeth. In the autumn they turn blackish, and have fodder given them. They are when young frequently afflicted with a soreness in the mouth, so as to be unable for a while to eat.

Reindeer are subject to a disease called by the Laplanders Peklie Kattiata, accompanied with ulcerations of the flesh, which 
however often heal by a sloughing of the part affected. This is an epidemic disorder. It is believed that if any of the ulcerous part, which is cast off, be swallowed by the animal, in licking his own coat, or that of any other of the herd labouring under this malady, it proves fatal by corroding the viscera.

The dugs of the female often become chapped or sore, so as to bleed whenever they are milked.

The male reindeer in his natural state is fatter than such as are castrated, except the latter be kept without work, in which case they become the fattest. Such as are castrated and allowed to run wild, become considerably larger, as well as tamer, in consequence.

The rutting season lasts but a fortnight, that is, from about a week preceding the feast of St. Matthew (Sept. 21.) to Michaelmas day, during which period the male is savage and dangerous. Immediately afterwards he casts his coat and horns, 
and not unfrequently becomes so emaciated, that, in many instances, death is the consequence.

Towards the feast of St. Eric (May 18.) in the following year, or within a fortnight of that period, very rarely later, the females bring forth their young. They do not copulate the first year, and seldom before the third, their progeny being found the better for this delay. Indeed neither the males nor females arrive at their full growth and perfection before they are towards three years old.

The fawn, whether male or female, is called the first year mesk; the second season the male is called orryck, and the female whenial. In the third year the latter, if she has been covered, is known by the appellation of watja or waja, which means a wife ; if otherwise, she goes by the name of whenial-rotha, the three-year old male being called wubbers. In his fourth year the male is termed koddutis; in the following one kosittis; in the sixth machanis, and in 
the seventh namma lappotachis. After that period no male is kept, they all perishing in consequence of the exhaustion above mentioned, but the castrated ones live to a more advanced age. None of these animals however survive beyond their twelfth or fourteenth year. When the castrated males become very fat towards autumn, and show signs of old age; or the females, having: become barren, appear otherwise to be on the decline, they are killed, by the knife, in the close of the year; from an apprehension that they might otherwise perish of themselves from infirmity, in the course of another season.

Such of the male reindeer as are destined to serve for a stock of provision, are killed before the rutting-time, and their carcases hung up to be exposed to the air and frost before flaying. The flesh is smolied and a little salted, and then laid upon sledges to dry in the sun, that it may keep through the winter till spring. About the feast of St. Matthias (Feb. 24.) the reindeer begin 
to be so incommoded with the gadl-fly, that they are not in a fit condition to be slain for eating. From that period therefore, till the milking season, the Laplanders are obligged to live on this stock of preserved meat. At other times of the year the females are killed for immediate use, according as they are wanted. The blood is kept fresh in kegs, or other vessels, and serves for food in the spring, being added to the vailling (see vol. 1.p. 129), with a small proportion of milk and water. The blood of these animals is thick in consistence, like. that of a hog. The Laplanders carry a portion of it along with them from place to place, in bladders or some kind of vessels. A stock of this and all other necessaries is collected as late as possible, before the melting of the snow, while there still remains a track for the sledges.

A kind of blood pudding or sausage is made, in general without flour, and with a large proportion of fat. This the Laplanders call marfi. 
The liver of the reindeer, which is of a considerable bulk, is boiled and eaten fresh. The lungs, being salted and moderately dried, are eaten occasiunally, or else given to the dogs. The intestines, which abound with fat, are cut open, washed, and boiled fresh; nor are they unpalatable. The brain and testicles are never eaten. The foot is flayed down to the fetlock joint, beyond which the hair cannot, by scalding or any other contrivance, be separated, without the cuticle and skin coming along with it. Even when the feet are boiled, the hair never comes off without the skin. Thus the animal when living is the more firmly protected against the snow. The hoofs are thrown away as useless.

The dung of the reindeer in summer is almost as large as cow-dung, but in winter it more resembles that of the goat.

Each individual reindeer does not bear horns of precisely the same shape every year. The points are very liable to be deformed, in consequence of the animal's 
scratching them, while in a growing statc, with its feet; they being in that state much inclined to itch, and as tender as the flesh of a fresh fish.

These animals are afflicted with maggots called kornmatskar in their noses and gums, from which they relieve themselves in the spring by snorting and blowing. When the insects lodge on their backs and form pustules there, the people make a practice of squeezing them out, to prevent the reindeer from being too much irritated by them. (This species is the Oestrus nasalis, though the account here given is not very clear; but in the first edition only of the Fauna Suecica Linnæus says, on the authority of a gentleman named Friedenreich, that " this Oestrus lodges its eggs in the frontal sinus of the reindeer in Lapland, and is frequently cast out by them as they travel along in the spring.")

When the skin is stripped from the carcase of the reindeer, it is immediately spread out, and stretched as much as pos- 
sible, by means of a longitudinal pole, and n transverse stick at each end of the skin, these sticks being pulled asunder with a strong cord. Several more transverse twigs are placed between these two sticks, so as to extend every part of the edges of the hide, which in this position is allowed to dry.

The Laplanders' gloves are made of skin taken from the legs of the animal; their hairy shoes, of that from its forehead between the horns, such being worth two dollars, copper money ; while those made from the skin of the legs, being much thinner, are of very little or no value.

A Laplander never goes barefoot, though he has nothing to serve him for stockings but hay (Carex sylvatica, Fl. Brit.). Sometimes he buys leather for shoes or boots fiom his neighbours.

The people of this country boil their meat in water only, without any addition or seasoning, and drink the broth. Jumomjölk (see vol. 1. 275.) liept for a whole 
year is delicate eating. Berries of all kinds are boiled in it. Some persons make a practice of boiling these berries by themselves, preserving them afterwards in small tubs, or other wooden vessels. They boil their fish more thoroughly than their meat, over a slow fire, drinking likewise the water in which it has been drest. The meat is never so much boiled as to separate from the bone. Fresh fish is sometimes roasted over the fire. Few people dry and salt it, though that method is sometimes practised. Meat is dried by the air, sun and smoke all together, being hung up in the chimney, or rather hole by which the smoke escapes through the roof.

The Laplanders never eat of more than one dish at a meal.

By way of dainty, the women occasionally mix the berries of the Dwarf Cornel (Cornus suecica) with Kappi (see vol.i. p.281.), which is made of whey boiled till it grows as thick as flummery. To this they 
moreover add some cream. That fruit is entirely neglected in the country of Medelpad.

In Dalecarlia the people generally keep their cattle up in the mountains, twelve or sixteen miles from their own dwellings, on account of gad-flies and other stinging insects. There they have their dairies, and make cheese. The remaining whey is boiled till two thirds are wasted, when it becomes as thick as flummery. This is sometimes eaten instead of butter, sometimes mixed with dough, or serves for food in various other manners.

The wind is excessively powerful in this alpine region, so that sometimes it is impossible to stand against it, both men and sledges being overturned by its violence.

It blew so hard at the place where I now was, that one of the windows of the curate's house was blown in upon the floor.

Every Laplander constantly carries a sort of pole or stick, tipped with a ferule, 
and furnished with a transverse bit of wood. Whenever he is tired, he leans his arms and nose against it to rest himself.

Such as live in the forests are dexterous marksmen, but not those who inhabit the alps. Nevertheless, they all contrive, by means of their wooden bows, to procure, in the course of the winter, a considerable number of Squirrels (Sciurus vulgaris) in their grey or winter clothing, for the sake of their skins.

In the winter season also they go in pursuit of their most cruel enemies the wolves. One of these animals will sometimes kill twenty or thirty reindeer at a time, if he comes into the enclosure where they are. The wolf often runs away before the Laplander can get near enough to fire at him. A bear can hardly catch a reindeer, except by coming upon it unawares, the latter being much the most swift of foot; but if he gets into any of the store-houses, he does a great deal of mischief, turning every thing topsy-turvy. Bears are also VOL. II.

E 
very dangerous in the fissures of rocks and mountains, where they usually conceal themselves.

The Glutton (Mustela Gulo) does most harm in the pantry or store-house. He never meddles with the reindeer.

A part of the employment of the men is to make sledges, or other machines of woad for carriage. They cut rough wood in the forests for the boxes which they carry with them into the alps.

The duty of the women is to mend the clothes of the whole family.

Laplanders have several plays or amusements.

Children make of the drvarf birch (Betula nanu) something like reindeer's horns, with which they gore one another in sport. They amuse themselies frequently by building little huts of stone.

Grown-up people play very well at tennis, but they seldom partake of that diversion. More common amusements are blindman's buff, and drawing gloves. 
Here I think it worth while to observe, that the alpine Laplanders are more honest, as well as more good-natured, than those who dwell in the woodlands. Having acquired more polish from their occasional intercourse with the inhabitants of towns, the latter have, at the same time, learned more cunning and deceit, and are frequently very knavish. The inhabitants of the alps dwell in villages formed of their tents, living together, as I have already related, in great comfort and harmony. Those who occupy the woody parts of the country live dispersed.

The Laplanders know no musical instrument except the lur (a sort of trumpet), and pipes made of the bark of the quicken tree or mountain ash. They are not accustomed to sing at church, except those who are reckoned among the great or learned of the community.

The inhabitants of this country are not more troubled with chilblains than those of other places. They do not mind 
having their cheeks frost-bitten. The women wear an embroidered band round the head, which affords no protection in this respect; but the men have a loose band of skin with the hair on, which can be pulled down occasionally over their cap, when the cold is intolerable.

(But to proceed with a further account of the diversions of the people I am describing).

Spetto, one of their games, is played, by men as well as women, in the following manner. They prepare from thirty to fifty or sixty pieces of wood, a hand's breadth in length, which are spread upon the extended skin of a reindeer. One of the players takes a ball made of stone or marble, larger than a boy's playing marble, which he throws up into the air about an ell high. While the ball is up, he snatches away one of the sticks, - but in such a manner as not to miss catching the ball in its fall, holding the stick in the same hand. He subsequently gathers together, 
in his other hand, as many of the sticks as he has thus been able to procure. If he fails in any respect, another person is to take the ball, and proceed in the same manner, the former player resigning up to him one of the sticks every time the ball is thrown, till no more remain in his own possession. He who can take up all the sticks wins the game.

The following rules are to be observed.

1. He who catches the ball, but not one of the sticks, must resign the ball to another player, as well as he who has let it fall.

2. He who takes up more than one stick at a time, must return what he has taken.

3. The adversary, that is, the last player, who could not succeed in taking up all the sticks, is allowed to lay down as many as he pleases of the sticks he has collected, and may airange them according to his fancy. It is usual to lay one upon, another, in order to render the game, more difficult, the player being obliged to 
snatch up each separately; which is not easy without taking two, when so situated, at once.

4. When at length one person has taken up all the sticks, his adversary is permitted to replace the two last of them upon the skin in any manner he chooses. He commonly separates them as widely as possible. The person who had previously gained the whole, is then required to take up both these sticks at one throw of the ball, and if he fails he must give up the game. Thus the victory is often lost by means of these two last sticks.

5. When the adversary fails of his aim, the other player is to take all the sticks Jying on the field, as well as those which, after having been laid down by himself, were won by the other person, and the whole are to be laid down again directly, in order to be taken up according to the above rules. But he is no longer under any obligation himself to take up the sticks which he has thus laid for his companion. 
THE LAPI AND ALPS.

The game called Tablut is played with a checkered board, and twenty-five pieces, or men, in the following manner.

\begin{tabular}{|c|c|c|c|c|c|c|c|c|}
\hline o & $n$ & $\mathbf{m}$ & & 4 & Y5s & $\mathrm{MI}$ & $\mathrm{N}$ & 0 \\
\hline 1 & $\mathbf{k}$ & i & $\mathrm{h}$ & 㮇 & $\mathrm{H}$ & I & K & $\mathrm{L}$ \\
\hline$g$ & $f$ & $\mathrm{e}$ & d & & D & $\mathrm{E}$ & $F$ & $\dot{G}$ \\
\hline & c & b & $\mathrm{a}$ & 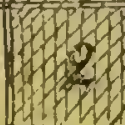 & $A$ & B & C & (is) \\
\hline & & 娞 & & & & & 2 & $(5)$ \\
\hline 垭 & $c$ & $b$ & $a$ & & $A$ & $\mathscr{B}$ & 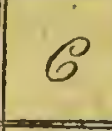 & $\begin{array}{l}\text { res } \\
\text { chs }\end{array}$ \\
\hline$g$ & $f$ & $e$ & $d$ & & $\mathscr{D}$ & $\mathscr{E}$ & $\mathscr{H}$ & $\mathscr{G}$ \\
\hline$l$ & h & $i$ & $h$ & A) & $\mathscr{H}$ & $\mathscr{I}$ & $\mathscr{K}$ & $\mathscr{L}$ \\
\hline 0 & $n$ & $m$ & & $\left\{\begin{array}{l}2+5 \\
54\end{array}\right.$ & 5 & 16 & er & $\%$ \\
\hline
\end{tabular}




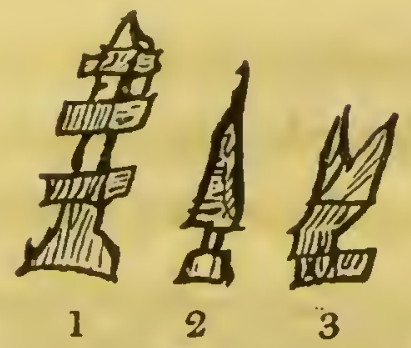

Fig. 1, is the king, whose station is in the central square or royal castle, called konokis by the Laplanders, to which no other person can be admitted.

Fig. 2, represents one of the eight Swedes his subjects, who, at the commencement of the game, are stationed in the eight squares, adjoining to the royal castle, marked 2 and 3.

Fig. 3, is one of sixteen Muscovites, their adversaries, who occupy the sixteen embroidered squares, (some of them marked 4 in the cut,) situated four together in the middle of each side of the field.

The vacant squares, distinguished by letters, may be occupied by any of the pieces in the course of the game.

\section{LAWS.}

1. Any piece may move from one square to another in a right line, as from $a$ to $c$; but not corner-wise, or from $a$ to $e$.

2. It is not allowed to pass over the heads 
of any other pieces that may be in the way, or to move, for instance, from $b$ to $m$, in case any were stationed at $e$ or $i$.

3. If the king should stand in $b$, and no other piece in $e, i$, or $m$, he may escape by that road, unless one of the Muscovites immediately gets possession of one of the squares in question, so as to interrupt him.

4. If the king be able to accomplish this, the contest is at an end.

5. If the king liappens to be in $e$, and none of his own people or his enemies either in $f$ or $g, i$ or $m$, his exit cannot be prevented.

6. Whenever the person who moves the king perceives that a passage is free, he must call out ruichi, and if there be two ways open, tuichu.

7: It is allowable to move ever so far at once, in a right line, if the squares in the way be vacant, as from $c$ to $\dot{n}$.

8. The Swedes and the Muscovites take it by turns to move.

9. If any one man gets between two squares occupied by his enemies, he is killed and taken off, except the king, who is not liable to this misfortune. 
10. If the king, being in his own square or castle, is encompassed on three sides by his enemies, one of them standing in each of three of the squares numbered 2 , he may move away by the fourth. If one of his own people happens to be in this fourth square, and one of his enemies in number' 3 next to it, the soldier thus enclosed between his king and the enemy is killed. If four of the enemy gain possession of the four squares marked 2, thus enclosing the king, he becomes their prisoner.

11. If the king be in 2 , with an enemy in cach of the adjoining squares, $a, A$ and 3 , he is likewise taken.

12. Whenever the king is thus taken or imprisoned, the war is over, and the conqueror seizes all the Swedes, the conquered party resigning all the Muscovites that he had taken.

The Laplanders use the middle bark of the elm for dressing their reindeer skins, but merely by chewing it, and rubbing their saliva on the skins.

They also tan with birch bark, but do not suffer the skins to remain long under 
the operation, which they say would render them rotten and apt to rend, neither can they spare them very long.

White roalmal cloth is procured from Russia, but for want thereof they commonly wear a light grey cloth of the same kind.

Ropes are made of roots of spruce fir in the following manner. Choosing the most slender roots, they scrape off the bark, while fresh, with the back of a knife, holding the roots against the thigh. Afterwards each root is first split with the knife into three or four parts, which are then by degrees separated into a number of very slender fibres; and these, being wrapped round the hand like a skain of thread, are tied together. They are then boiled in a kettle for an hour or two, with a considerable quantity of wood ashes. While still soft from this boiling, they are laid across the knee, and scraped three or four times over with a knife. At last they are twisted into small ropes. Birch roots serve in like manner to afford cordage for the Laplanders, but more rarely. The 
latter are more generally used, without being split, for basket-work. For various articles of furniture the roots of Tall (Scotch Fir, Pinus sylvestris) are cut into small boards. The wood of that tree serves for inferior kinds of work, and, amongst other things, for cheese-vats.

The Laplanders scrape with a knife the young and tender stalks of the plant called Jerja, (Sonchus alpinus, Sm. Plant. Ic. t.21.) and eat them as a delicacy, like those of the great Angelica (A. Archangelica), which in the first year of their growth are termed Fatno.

A Laplander always places himself at the further part of his hut, and his guest is seated next to him on a skin spread on purpose. The master of the hut is by this means enabled to reach the vessel in which water is kept for drink, and which always stands in the upper part of the hut.

The river Hyttan flows in a perpetual stream both summer and winter. Now if, according to the general opinion, the water of this river were derived from exhala- 
tions of the great ocean, collected by the alps of this country, it should cease to run when all the alpine tracts are frozen. The stream must therefore be constantly fed by neighbouring springs.

The names by which the Laplanders distinguish the several times of the day or night are as follows.

Midnight is called in their language kaskia. The remainder of the night before dawn, pojela kaskia. The morning dawn, theleeteilyja. Sun-rise, peivi morotak. Two or three hours after sun-rise, areiteet. The hour of milking the reindeer, which is about 8 or 9 o' clock, arrapeivi. Noon, or dinner time, kaskapeivi. About 5 or 6 o' clock in the afternoon, eketis peivi. Sunset, peiveliti. Night, iai.

The days of the week are named as follows.

Sunday, Sotno peivi.

Monday, Mannutaka.

Tuesday, Tistuka.

Wednesday, Kaska vacku, or middle of the week. 
Thursday, Tourestaka.

Friday, Perietaka.

Saturday, Lavutaka.

They have no names for the months, but certain weeks are distinguished by the following appellations.

Midsummer week. Midtsomarvacku.

St.Peter's week, June 29, Pelasmassu vacku.

Goose week, Gassa vacku.

In the middle of the summer, Gaskakis.

St. Margaret's, July 20, Marcrit.

St. Olaus' mass, July 29, Vollis.

(No date mentioned here.) Vehak.

St. Laurence, Aug. 10, Lauras.

Reindeer-fawn week, Orryk. When in a

fawn two years old the horns begin to bud.

St. Bartholomew, Aug. 24, Barti.

(No date.)

Hoppmil.

St. Mary, Sept. 8, Margi.

Holy Cross, Sept. 14, Behawis.

St. Matthew, Sept. 21, Matthus.

St. Michael, Sept. 29, Michel.

(St. Faith, Oct. 6?) Perkit.

(Middle of Oct.) Talvi. 


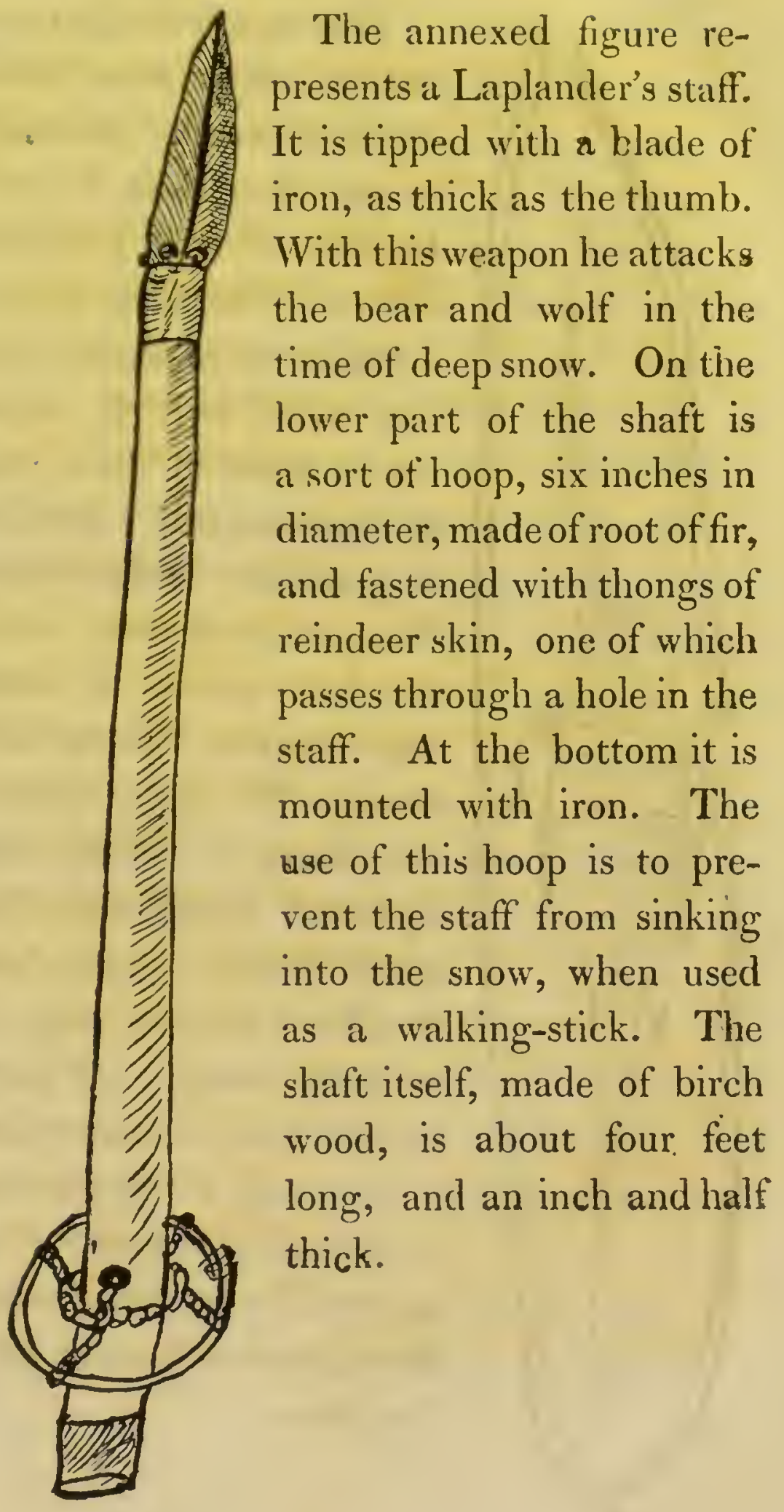




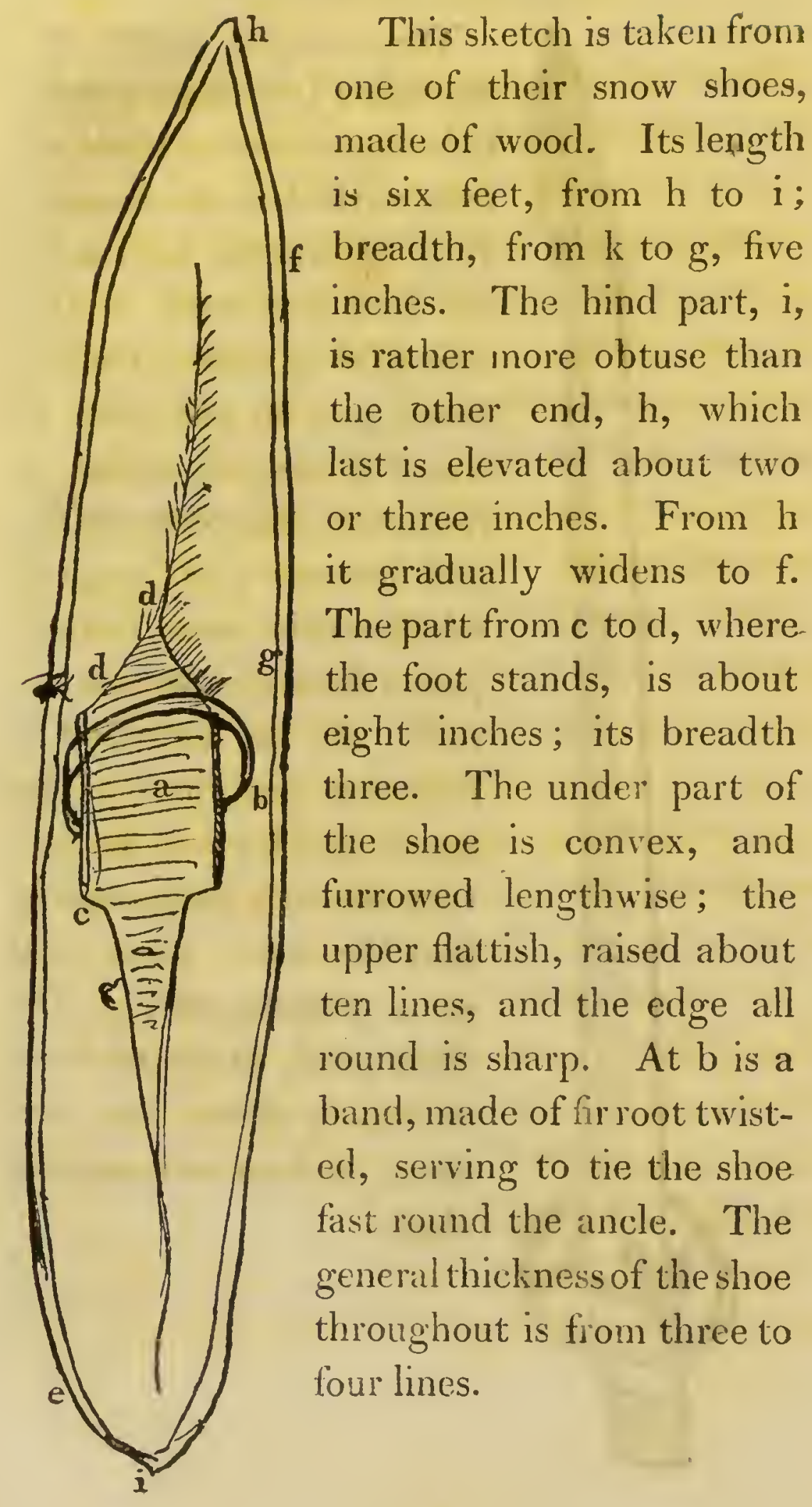


Some people wear a pair of the same size; others have the left shoe smaller than the right. Each is often lined or covered, about the central part, with a piece of hairy reindeer slin, to prevent the foot slipping about upon the shoe, and give a firmer step in walking over the snow. This is most practised in KimiLapmark, where the wild reindeer are most abundant.

The Lapland thread is made out of the tendons of reindecr fawns half a year old. Such thread is covered with tin foil for embroidery, its pliability rendering it peculiarly fit for the purpose. The tendons are dried in the sum, being hung over a stick. They are never boiled.

To show to what a high degree of perfection these people have arrived in the art of making such thread, I brought away a sample of it, which I believe none of our ladies could match.

Shoes and baskets made of birch bark are used both in Angermanland and HelVOL. II. 
singland, as well as ropes of the same material, which will not sink in water, but these are not in general use.

The bors which serve the Laplanders for shooting squirrels are composed of two different kinds of wood, laid parallel to each other. The innermost is birch, the outermost of what they term kior, kioern or tioern. (This is procured from a tree of the Common Fir, Pinus sylvestris, that happens to grow in a curved form, usually in marshy places, or on the banks of rivers, and whose contracted side is hard like box: see vol.i. p. 255 ; also Fl.Lapp.n. $346, \lambda$.) If this be not practised, the bows are more apt to snap. Each layer of wood is externally convex, yet not so much as to render the bow quite cylindrical.

When the Laplanders ex pect any visitors, they are particularly careful to have plenty of ris (branches of the dwarf birch) spread on the floor, under the reindeer skins on which they sit; otherwise they would be thought deficient in civility, and the mis- 
tress of the family would be censured as a bad manager, when the guests returned to their own homes.

The mode of their entertainment is as follows.

First, if the stranger arrives before their meat is set over the fire to boil, they present him either with iced milk, or with some kind of berries mixed with milk, or perhaps with cheese, or with kappi, (see vol.i.p.281.) Afterwards, when the meat is sufficiently cooked, and they have taken it out of the pot, they put into the water, in which it has been boiled, slices of cheese made of reindeer milk. This is a testimony of hospitality, and that they are disposed to make their guest as welcome as they can. They next serve up some of their dry or solid preparations of milk.

The marriages of the Laplanders are conducted in the following manner. (This subject was treated in vol. i. p. 276, like Sterne's " history of the king of Bohemia and his seven castles," no doubt to the 
great dismay of the curious reader. We ought to have warned him of its being resumed in a subsequent part of the work, but in truth we had not then ourselves proceeded so far in decyphcring the original manuscript.)

1. In the first place the lover addresses his.favourite fair-one in a joking manner, to try whether his proposal be likely to prove acceptable or not. Perhaps he even goes so far as to speak once or twice to her father upon the subject. He then takes his leave, either fixing a time for his return, or not, as it may happen.

2. The lover next takes with him such of his nearest relations as live in the neighbourhood, who, as well as himself, all carry provisions with them, to the hut of his mistress, he going last in the procession.

3. When the party arrive at the place of their destination, they all, except the lover, walk in. If there happen to be any other huts near at hand, it is usual for the damsel to retire to one of them, that she 
may not be obliged to hear the conversation of the risitors. Her admirer either remains on the outside of the door, amongst the reindeer, or goes into some neighbouring hut. There are usually two or three spokesmen in the party, the principal of whom is called Sugnovivi. When they are all seated, the young man's father first presents some brandy to the father of the young woman; upon which the latter asks why he treats him with brandy? The former replies, "I am come hither with a good intention, and I wish to God that it may prosper." He then declares his errand. If the other party should not be favourably inclined to the proposal, he rejects it, at the same time thanking the person who made it. Upon this, all who are present endeavour to prevail upon him to give his consent to the marriage. If they succeed, or in case the offer has from the first been accepted, the friends of the lover fetch whatever they have brought along with 
them, consisting of various utensils, and silver coin, which they place on a reindeer skin, spread in the hut, before the father and mother of the intended bride. The father or the mother of the bridegroom then distributes the money between the young woman and her parents. If the sum be thought too small, the latter ask for more, and it frequently happens that much time is spent in bargaining, before they can come to a conclusion. When the parties concerned cannot obtain so large a sum as they think themselves entitled to, they. often reject the whole, and return the money to those who brought it. But if, on the contrary, matters are brought to a favourable conclusion, the parents allow their daughter to be sent for. Two of the bridegroom's relations undertake this office. If the bride has any confidential female friend, or a sister, they walk arm and arm together; and in this case the mother of the bridegroom is required to make a pre- 
sent of a few brass rings, or something of that kind, to this friend or sister, who keeps lamenting the loss of her companion.

When the bride enters the hut, her father asks whether she is satisfied with what he has done? To which she replies, that she submits herself to the disposal of her father, who is the best judge of what is proper for her. The mother of the bridegroom then presents the bride with the sum allotted for her, laying it in her lap. If it proves less than she had expected, she shows her dissatisfaction by rarious gestures, and signs of refusal, in which case she may possibly obtain at least the promise of a larger sum. All these gifts become her own property.

When such pecuniary matters are frnally arranged, the father and mother of the bridegroom present him and his bride with a cup of brandy, of which they partake together, and then all the company shake hands. They afterwards take off their caps, and one of the company makes an oration, 
praying for God's blessing upon the newmarried couple, and returning thanks to him who "gives every man his own wife, and every woman her own husband."

The parents of the bridegroom next partake of some brandy, and the whole stock of that liquor which they had brought with them is fetched for the company.

All the relations of the bridegroom then come forward with their provisions, which generally consist of several cheeses, and a piece of meat dried and salted. The latter is roasted before the fire, while the company is, in the mean while, regaled with some of the solid preparations of milk, the bride and bridegroom eating by themselves, apart from the rest.

Two stewards are next chosen, one of them from the bride's party, the other from that of the bridegroom. The lastmentioned party are then required to furnish a quantity of raw meat, amounting to about a pound and half to each person. This the stewards immediately set about 
boiling, and their duty moreover is to serve it round to all present. This meat is dressed in several separate pots, two only in each hut, if there be any neighbours whose huts can serve to accommodate the party on this occasion; for each Laplander has never more than one hut of his own. The fat part of the broth is first served up in basons. Afterwards various petticoats or blankets, of walmal cloth, are spread on the floor, by way of a table-cloth, on which the boiled meat is placed. The chief persons of the company then, as many as can find room, take their places in the hut of the bride's family, sitting down round the provision, while the children and inferiors are accommodated in the neighbouring huts. Grace is then said. The bride and bridegroom are placed near together, for the most part close to the door, or place of entrance. They are always helped to the best of the provision. The company then serve themselves, taking their meat on the points of their knives, 
and dipping each morsel into some of the fat broth, in which the whole has been boiled, before they put it into their mouths. Numbers of people assemble from the neighbourhood, to look in upon the company through the door; and as they expect to share in the feast, the stewards give them two or three bits of meat, according as they respect them more or less. What remains after every body is satisfied, is put together, and wrapped up in the blankets or cloths, that part of it which is left by the new-married couple being kept separate from the rest, as no other person is allowed to partake of their share. The dinner being over, the whole company shake hands and return thanks for their entertainment. They always shake hands with the bride and bridegroom in the first place, and then with the rest, saying at the same time kusslăn.

After taking some brandy, the whole party go to bed. The herd of reindeer had been turned out to pasture from the 
time when the meat was put into the pot. The bride and bridegroom sleep together with their clothes on.

When the company rise in the morning, if the bridegroom's father and their party have any thing left, they treat the others with it; for the family of the bride have seldom any preparation made, not expecting, or not being supposed to expect, such company, and they never keep any brandy by them, but purchase it for every occasion. Whatever cold meat therefore remains is brought forward, to which the bride's party indeed add cheese, and any other preparation of milk they may have in store, as well as any dried meat; such things being usually kept by them. With these the party regale themselves by way of breakfast. Afterwards the family of the bride boil some fresh meat, as a final repast for their guests, who, after partaking of it, take their leave.

The banns are usually published once. The marriage ceremony, which is very 
short, is performed after the abovementioned company is departed. This being over, the bridegroom either takes his wife immediately home with him, or he goes to his own hut alone, and stays there from one to five days, after which he returns to her residence, bringing with him his herd of reindcer, and stays there for some time with her.

Such of the Laplanders as are rich enough to afford it, make their wives a present of a coverlet; a petticoat made of cloth, without any gathers, as usual among these people; a small silver beaker or cup; several rix-dollars and silver rings; a spoon, \&c; so that many a bride costs her husband more than a hundred dollars, copper money. To the mother he perhaps gives a silver belt, as well as a cloth petticoat.

I have already mentioned that the Laplanders eat Angelica (sylvestris) in a raw state. This plant, which the inhabitants of Westbothland call Bioernstut, has so many names among the Laplanders, ac- 
cording to the different stages of its growth, as to cause much confusion to a stranger. The first year of its growth they term the root Urtas, and the leaves Fadno; but the second year the plant is knorvn by the name of Posco or Botsk. When the stalk is dried, or eaten raw, they call it Rasi, that is, grass. They say, when any one has eaten more of this plant than is good for him, "Elli rasi ist purro etnach," the meaning of which is, "Thou hast overloaded thyself with such a quantity of grass."

Another herb of which they are very fond is the Sowthistle with a simple stem, known by the name of Jerja. (Sonchus alpinus. Fl. Lapp.ed.2.240. Sm. Pl. Ic. t.21. S.lapponicus. Willd.Sp.Pl.v. 3. 1520.) This has a perennial root. The stem is erect, round, green, smooth, except a few soft scattered hairs, which are most remarkable towards the top and bottom, and is almost as tall as a man. Leaves about twelve or fourteen, half clasping the stem, gradually smaller upwards, nearly 
the shape of Dandelion, or of the common Sowthistle, one half of each leaf, consisting of the terminal lobe, making exactly an acute triangle, toothed at the edges ; from that part downwards the leaf contracts, but not to the main rib, and then again expands into two narrow appendages, as it were, equal in breadth, but unequal in length, which are crenate at their edges. From thence begins the stalk of the leaf, which is winged and toothed, and half embraces the stem. The leaves are thin and smooth, with a rib purple on the upper side, and the upper ones are the least divided, as well as the bluntest. The flowers are collected into a corymbus, somewhat like Butterbur, but more loosely, especially in the lower part, each supported by a very short stalk, accompanied by a very narrow oblong leaf which extends beyond the flower. The calyx consists of several oblong, narrow, acute, imbricated leaves, varying in number from fourteen to twenty, the outermost gradually shortest, but the 
ten innermost are equal in length, and blunter than the rest, composing two rows; the calyx altogether is shorter than the corolla, tubular, swelling, and downy. Florets equal in number to the leaves of the calyx. Germen short, square, crowned with long white radiating down. Petal flat, cut away on one side, violet-coloured, five-toothed. Stamens five, white, their apex (anther) cylindrical, fire-sided, white, marked with five blue lines. Pistil one, forked at the top. Receptacle naked, dotted. This plant grows among trees at the sides of mountains, along with the narrowhooded Aconite (Aconitum lycoctonum), flowering at the end of July or beginning of August. The stem, which is milky, is eaten by the Laplanders in the same manner as Angelica. The taste was to me very bitter, but the people of the country do not find it so, though they confessed that it appeared bitter to them when they first learned to eat it. As soon as the plant 
shows its flowers, the stalk becomes woody, and no longer eatable.

The sinews of which the fine thread is made that, when covered with tin, serves for embroidery, and is called tentrid (tinthread), are taken from the feet of the reindeer, or of oxen, boiled ; though sometimes the feet of sea-fowl are chosen for this purpose. Old women and girls are employed in preparing this thread, by drawing it through holes made in a piece of reindeer's horn. They wind it round their hands and feet as they form it, and smear it with fat extracted from the foot of the animal, to make it more supple, as they proceed.

Hay is made in different modes in various parts of Sweden. In Westbothland the fresh-cut grass is heaped together over night, that it may get a heat. Next day it is spread out, and by this method its quality is supposed to become richer and stronger. The same is practised with hops 
in Jamtland, where the fresh-gatheredhops are packed together, as hard as possible, till they become warm; after which they are spread out to dry. Their strength is by this means improved.

The people of Scania having mowed their grass, let it lie till dry, when they rake it together.

The Smolanders dry it in a kind of shed.

The East Gothlanders range it in heaps, two and two together, in a long row.

In Upland the new-mown grass is tied up in bundles, and collected into cocks.

In Angermannia the whole year's crop is laid by upon a kind of raised floor.

In Westbothland, after being dried in the shed, the hay is kept there for use, being laid crosswise, and cut when wanted*.

\section{July 23.}

This evening I took leave of the alpine

* The whole of this account of the hay consists, in the manuscript, of such concise, disjointed, and obscure notes, that we are by no means certain of having preserved the exact sense.

VOI. II. 
part of Lapland, and returned by water from Hyttan towards Lulea.

'The White, or Mountain, Fox (Canis lagopus) lives among the alps, feeding on the Lemming Rat or Red Mouse, (Mus Lemmus,) as well as on the Ptarmigan (Tetrao Lagopus). This White Fox is smaller than the common kind. The Ptarmigan, which the Laplanders call Cheruna, feeds on the Dwarf Birch (Betula nana), which for that reason is called $R$ yprys, or Ptarmigan-bush. At night this bird lies squat upon the snow, in the same posture as the Wood Grous (Tetrao Urogallus, see vol. 1. 179): hence a great deal of its dung is seen in the prints it makes in the snow. This mode of roosting renders the Ptarmigan an easy prey to the Fox.

The Lemming or Red Mouse, see p. 18, (Mus Lemmus,) in some seasons entirely overruns the country; devouring the corn and grass: but though these animals thus occasionally appear by millions at a time, they subsequently depart and disappear as unaccountably, so that nobody knows what 
becomes of them. They do no mischief in the houses.

The Ermine (Mustela Erminea) is white in winter, red in summer. This animal is seldom met with on the alps, but is very plentiful in the forests. Foxes and Wolves have destroyed the chief of the Hares. The Wolves indeed kill the Foxes.

The Shrew Mouse (Sorex araneus) and Common Small Mouse (Mus Musculus) are found in Lapmark, but no Rats (Mus Rattus).

Hunting the Bear is often undertaken by a single man, who, having discovered the retreat of the animal, takes his dog along with him, and advances towards the spot. The jaws of the dog are tied round with a cord, to prevent his barking, and the man holds the other end of this cord in his hand. As soon as the dog smells the bear, he begins to show signs of uneasiness, and by dragging at the cord informs his master that the object of his pursuit is at no great distance. When the

G. 2 
Laplander by this means discovers on which side the bear is stationed, he advances in such a direction that the wind may blow from the bear to him, and not the contrary; for otherwise the animal would by the scent be aware of his approach, though not able to see an enemy at any considerable distance, being half blinded by the sunshine. When he has gradually advanced to within gunshot of the bear, he fres upon him; and this is the more easily accomplished in autumn, as the bear is then more fearless, and is continually prowling about for berries of different kinds, on which he feeds at that season of the year. Should the man chance to miss his aim, the furious beast will directly turn upon him in a rage, and the little Laplander is obliged to take to his heels with all possible speed, leaving his knapsack behind him on the spot. The bear coming up with this, seizes uponit, biting and tearing it into a thousand pieces. While he is thus venting lis fury, and bestowing all his attention, upon the linapsack, the Lap-- 
fander takes the opportunity of loading his gun, and firing a second time; when he is generally sure of hitting the mark, and the bear either falls upon the spot or runs away.

\section{July 24.}

In the huts of this neighbourhood I observed an instrument which I had no where noticed before, consisting of an oblong board, placed transversely at the end of a pole. Its use is to stir the pot while boiling.

Directly opposite to Hyttan towards the west, and on the south of the mountain of Wallivari, is a vein of fine iron ore, but hardly worth working while the roads, by which it must be conveyed to Lulea, are in so bad a state.

This night I beheld a star, for the first time since I came within the arctic circle. Nevertheless the darkness was not considerable enough to prevent my reading or writing whatever I pleased.

One of the Laplanders had caught a 
quantity of the fish called Sililoja (Satmo Albula) of a large size. He stuck about twenty of them on one spit, the back of each being placed towards the belly of the next, and they were thus roasted before the fire. These fish had previously been dried, though not at all salted.

The glue used by the Laplanders for joining the two portions of different woods of which their bows are made (see p.66,) is prepared from the Common Perch (Perca fluviatilis) in the following manner. Some of the largest of this fish being flayed, the skins are first dried, and afterwards soaked in a small quantity of cold water, so that the scales can be rubbed $\_f f$. Four or five of these skins being wrapped up together in a bladder, or in a piece of birch bark, so that no water can get at them, are set on the fire in a pot of water to boil, a stone being laid over the pot, to keep in the heat. The skins thus prepared make a very strong glue, insomuch that the articles joined with it will nover separate again. 
A bandage is tied round the bow while making, to hold the two parts the more firmly together.

When these people undertake a short journey only, they carry no bag for prorisions, the latter bcing stored between their outer and inner jackets, which are always bound with a girdle, being wide, and formed of numerous folds, both above and below it.

The Purple Willow-herb, or Epilobium (angustifolium?) made the fields at this time very beautiful. The Golden-rod (Soliclago Tirgaurea) was likewise here in blossom, though not yet upon the alps, where it flowers later.

I have never yet seen any animal swim so light as the reindcer. During the dogdays the herds of reindeer, belonging to the inhabitants of the woody parts of Lapland, are very badly off for want of snow, with which those animals refresh themselves in hot weather upon the alps. Hence they constitute a more valuable and thriring pro- 
perty to the alpine Laplanders than to any others. In the winter time, when the favourite Lichen of the reindeer (L. rangiferimus) cannot be got at, their keepers fell trees laden with filamentous Lichens, to serve them for food; but it scarcely proves sufficient.

The rivulet near Kiomitis Trask has a very white appearance, as if milk had been mixed with it. This the inhabitants term kalkwatter, or lime-water, from the colour, not from any knowledge of its cause or origin. This rivulet they told me came from the alps. It empties itself into the great river near Kiomitis, and renders the water of that river white for the space of four or five miles. I noticed a similar. phænomenon at Wirijaur.

I was amused with the mode in which these Laplanders take brandy. After they have laid hold of the mug, they dip their forefingers into the liquor, and rub a little on their foreheads, as well as on the middle of their bosoms. On inquiring the reason, 
I was told their intention was that the brandy might not prove hurtful either to the head or breast.

Some people here were regaling themselves with fresh fish, of the kind lately mentioned (Salmo Albula), which having boiled into a mass like pap or fummery, they were eating out of their hands.

The diess of the Laplanders is, in one particular at least, very wisely contrived. Their thick collars effectually protect the throat and breast, which being furnished with numerous nerves and small muscles, and being the seat of the windpipe and of many principal veins and arteries, are very important and susceptible parts. The neck moreover, from its slender shape, is peculiarly exposed to cold. Hence the protection of clothing is found very necessary to the parts in question. For want of it our young women suffer much injury, which our youths avoid by running into the contrary extreme of tying their neckcloths 
so tight as to make themselves as red in the face as if they were half strangled.

We Swedes are accustomed to have all our clothing made very tight. Not only the neckcloth, but the coat, waistcoat, breeches, stockings, sleeres, \&c., must all stick close to the body, and the tighter they are the more fashionable. The Laplanders, on the contrary, wear only two, and those slight, bandages about them, which moreover are broad, and therefore less injurious than a narrow bandage in any part. Those to which I allude are the waistband and knees of their breeches, both made sufficiently loose and easy.

To-day I gathered the following plants. - A reed-like panicled Grass, with a very slender branched stem. (This appears to have been Arundo Calamagrostis, Fl.Lapp. n. 42.)

A great aquatic Carex, with inflated, whitish, pendulous spikes. In more dry situations they were upright and shorter, 
but in every other particular the same. (C. zesicariu.) A grass with a slender darkcoloured panicle, approaching the stem. (Agrostis rubra, Fl. Lapp.n. 46.)

\section{July 25.}

The lakes in this part of the country did not afford me so many plants as further south. Their bottoms were quite clear, and destitute of vegetation. Their shores were no less barren. No Water-lilies (Nymphac), no Water-docks, \&c., (different śpecies of Rumer, grew about their borders, but the surface of the water itself was covered with the Water Ranunculus ( $R$. aquatilis), bearing round as well as capillary leaves, and whitening the whole with its blossoms. I could not but wonder to see these broad patches of white spread over the lakes, though, when I passed up the country but a fortnight before, I had not perceived the least appearance of even the herbage of the Ranunculus that composed them. Now its 
branches, an ell in length, swam on the surface. The growth of the stem must be very rapid, as it often proceeded from a depth of three fathoms. Some of the plants thrown up on the shore had capillary leaves, as are all those which grow under the water. The root resembles that of the Iris.

I noticed also the Pondweed with leaves clasping the stem (Potamogeton perfoliatum, rare in Lapland); and a very large branched floating Water-grass, with cylindrical spikes, which I hesitate whether to separate from the Gramen aquaticum genicillatum spicatum, (of Baubin and Rudbeck. Alopecurus'geniculatus of Linnæus. The grass of which he here spealis is $n .38$ of his Flora Lapponica. A. geniculatus $\beta$, Sp. Pl. 89.)

The annexed figure represents the Norwegian cross-bow, used for shooting squirrels, which it will hit at the distance of twenty or thirty paces as certainly as a gun. It was curious to observe the dexte- 


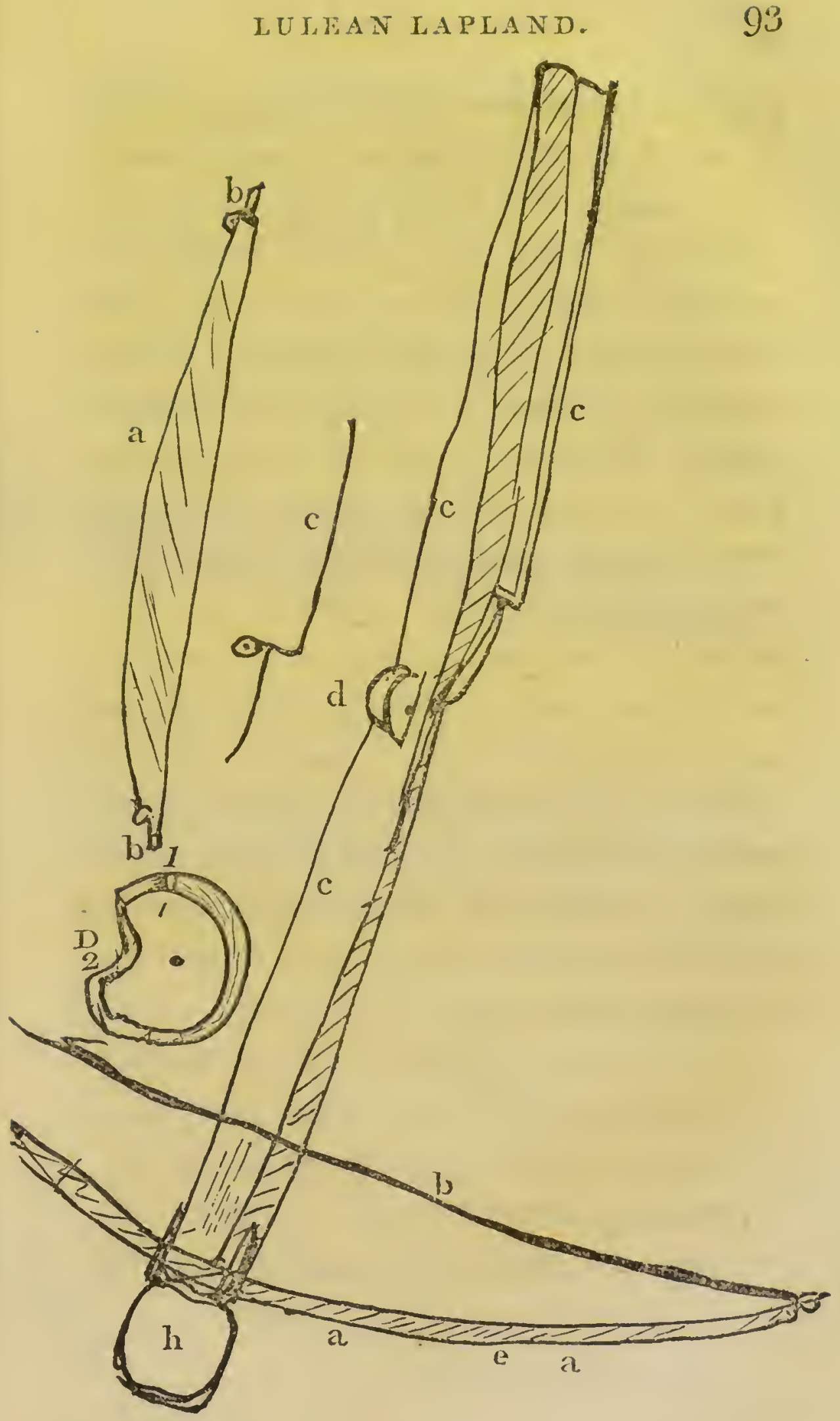


rity with which one of the Laplanders hit a small fly, which I had set up for a mark, at the distance of thirty paces.

The bow itself, a, a, a, made of steel, is two feet and a half long, two inches wide in the middle, gradually sloping off to the extremities, which are only one inch in width. Each end is rounded, with a notch, where the cord is fixed, which, when the bow is drawn, seems in danger of immediately slipping off, but it never does. The whole bow when at rest makes a curve of two inches; when strongly bent it forms one of seren.

The cord $b$, fixed on at the ends $b, b$, is made of twisted hemp, as thick as one's finger, bound round with hempen thread, especially in the middle, where it is to receive the bolt.

The stock c, c, made of wood ornamented with inlaid work of bone, is two feet and a half long, and half a palm broad, being half an inch thick towards the top, and an inch at the base. Its upper side is entively covered 
with the above-mentioned inlaying, and quite even or flat, except towards the base or handle, where it is slightly concave.

The part marked $d$ on the bow, and D on a larger scale annexed, is the catch, like a pullcy, which turns on an iron pin, and in the side of which is a projection, with a rectangular notch, see fig. 1 and 2 . When the bow is bent, the angle at fig. 2 catches the cord, and is let go by means of the apparatus represented at $\mathrm{c}, \mathrm{c}$, by the side.

As no human being is sufficiently strong to draw this bow with the hands alone, a strap of leather is fixed round the loins, ending in two iron hooks, which lay hold of the cord. One foot is put into the strap at the top of the bow, h, and then, by the exertion of the body, the bow is drawn till the cord catches the angle of the pulley $\mathrm{D}$. 
The annexed cut represents the bolt of this Norwegian crossbow, which is a foot and half long, an inch thick. From the extremity, which is thicker and blunt, to the feathered part, is about a foot. The feathers, taken from the wing of the great Grous or Cock of the wood, (Tetrao Urogallus,) are stripped from the quill, and placed erect in three longitudinal rows; and after being bound on with thread, the part by which they are attached is smeared with pitch, to fix them the more firmly. The whole bolt is made of birch wood. Its base is compressed, naked and smooth, formed with a groove to receive the bow-string.

This more finished and elaborate sort of bow is principally used in Westbothnia. The whole cost of one, with all its appurte- 
hances, amounts to fifteen dollars, copper money. The Laplanders therefore content themselves with a far more rude and simple apparatus, consisting of such a wooden bow made of birch, as I have already described, with a string fitted to it. Or they merely cut a branch of fir in the forest, and with any bit of cord that happens to come in their way, kill abundance of squirrels, holding the bow with their left hand, and drawing it with their right by means of a small cleft stick. Thus they will, as I have witnessed, take successful aim at the Emberiza nivalis, or Snow Bunting, sitting on the tops of the most lofty pines.

It is commonly reported that no clay is to be found in Lapland, but I met with some in two different places; in each instance indeed it was at the bottom of a lake, as at Rondijaur and Sckalka trask, the shores being of sand though the bottom was clay.

Nets are set in the lakes in winter to catch the Sijk fish (Salmo Lavaretus, or VOL. II. 
Gwiniad.) Holes are made for this purpos: in the ice, and the nets are dragged with a string. This is done from St. Andrew's day, (Nov. 30th,) to Christmas.

The Laplanders make their sledges serve for chests, when they are not used for their proper purpose, by constructing a sort of roof or convex covering, with an opening in the middle, to admit whatever they choose to store up within. This opening shuts with a morcable lid. Sledges in this state occasionally serve for the conveyance of goods from one place to another, the covering keeping them dry.

Caps are marle of the skin of the Colymbus arcticus, (Black-throated Diver, which is very tough when properly prepared. This bird has a grey ring round its neck, as described by Wormius.

I met with a Carex, bearing round capsules, full of black powder. (Probably Carex panicea, whose seeds are often infected with the ustilugo or smut.) 


\section{July 26.}

I shall here give a description of the Achier or sledge. This is a kind of travelling machine invented by the Laplanders, drawn along the ground like other sledges, and made of birch wood. The back part is upright, or nearly so, the lower part only being somewhat sloping inwards, and its form is roundish, the height a foot, the breadth a foot and a half. The body of the machine is like the hulk of a boat, with an obtuse keel, and consists of five longitudinal boards on each side, lying one over the edge of another ; that which forms the keel being about an inch thick, and lying fiat like the others. Each board is not externally plane, but convex, so that as the carriage is drawn over the snow it leaves several tracks or lines where it goes, the board which forms the keel only being quite flat. The boards, which are fixed at one extremity in a circular manner to the roundish board that makes the back, (or as 
it were the stern,) are collected by their points at the other, and all bound together with a rope, for there are no nails to fasten them. The whole carriage is six feet in length, and from the back part to within two feet of the front its breadth is all the way about four feet. From that spot the keel begins to curre upwards, and the transverse dimensions are contracted gradually to a point. This sledge is drawn by a rope that goes through a hole in the front of the keel. The edges or sides of the machine do not curve outwards, but rather invards. When any covering is to be put on, which is always done in part when any person is to trarel sitting in this carriage, and entirely, from one end to the other, when it is intended to be used for the conreyance of groods, two or three semicircular or archlike bows are erected, fixed by their ends within the edges of the carriage, which serve to support a corering of sealskin, or cloth, whose margin next the back is loose, and so far distant from that part 
as to allow the traveller to sit upright, his legs lying under the cover, while the said margin is tied round his waist, like an apron, serving to keep the snow out of the hollow part of the machine. The person of the traveller is further secured by strings fixed to the edges of the carriage, which lace around him across the top, so as to prevent his being thrown out by any oblique or unexpected norement. Each board, which composes the body of the sledge, is somewhat convex on the inside, but still the whole internal surface is sufficiently smooth and even. The point in front sometimes projects a foot beyond the hollow part".

* La Motraye, after describing the Lapland sledge, observes that " it is attached by a single trace or thong, passing under the belly of the reindeer, and fixed to a leather collar which goes round the animal's neck: A long cord made of twisted fir bark, tied to his horns, serves, when pulled in a straight line, to stop his course, or, when drawn loward either side, to turn him in that direction. When this cord is made to strike him gently, by a vertical motion, on 
It is worthy of notice that the Laplanders use no almanack, but in its stead only a kind of instrument like the ancient runic calendar of the Goths, composed of seven small splinters or boards. They have indeed names to mark some periods, as already mentioned p. 62 ; but they do not, like us, compute time by the month, but by the course of their various holidays. They have also a name for every week. They are unable to tell when an eclipse of the sun or moon is to be expected. The year begins, by their reckoning, on the Friday before Christmas day.

The people in the part of the country where I was now travelling wear, in summertime, either a coat of walmal cloth next the skin, or no coat at all, only a lappmudd as they call it, (or garment of reindeer skin,) stripped of its hair.

the back, it urges him to greater specd. The overturn of the sledge, where the road is uneven, is prevented by a stick, which serves, like the oar or paddle of a boat, to guide its course." 
At sun-set we reached Purlijaur, where we in vain attempted to procure a boat. We had no resource but to make ourselves a float or raft, on which we committed our persons and all our property to the guidance of the current of the river. The night proved very dark in consequence of a thick fog, insomuch that we could not see before us to the distance of three fathoms. After a while we found ourselves in the middle of the stream, and it was not long before the force of the water separated the timbers of our raft, and we were in imminent danger of our lives. At length however, with the greatest difficulty, we reached a house situated on an island, after a voyagge of half a mile from where we embarked*.

* Linnæus records this misfortune in his Flora Lapponica, at n. 42, see ed. 2. p. 27, where, in speaking of Arundo Calamagrostis, he says he " presumcs the synonyms are rightly applied, though he had no opportunity of comparing his plant with books and descriptions, having lost the specimen, with various other natural productions, by being cast away as he 
At Purkijaur I hired a man to show me the manner of fishing for pearls, for which I agreed to pay him six dollars. He made a raft of five timbers as thick as my body, and two fathoms in length. At fach end was a staple to which the anchor was attached. This anchor was nothing more than a stone, tied round with twigs of birch that it might not be lost, to which he fastened a cord, about two fathoms in length, made of birch twigs. He was likewise furnished with a pole of the same length, which served him to steer his raft, as it floated along the strong current. The bottom of the river is not easily seen at any great depth; but when he could distinctly perceive it, he dropped his stone anchor, fixing the upper end of the rope to the staple on the raft, by which it became stationary. Whenerer he wished to examine another spot, he weighed anchor, and re-

was descending one of the great rivers of Lapland." The synonym of Morison at least, which he has thus by memory applied, proves to be erroneous. 
signed himself to the force of the current. Where the water was shallow, he stood upright on his raft; but where the depth was considerable, he lay at full length, with his face downwards, looking over the edge of the raft.

By means of a pair of wooden pinceis, two fathoms in length, he laid hold of the pearl oysters (anther muscles, Mya margaritifera, and drew them up. The part of the pincers below the joint or hinge was about a span long, and of three fingers breadth, hollowed out at the points, one of which was curved, the other flat. Taking the other end of these pincers in his hands, he casily directed them to the spot where he saw the shells lying.

The latter were generally open, so that they might readily be discerned by the whiteness of their inside; but when the water is very much agitated, the animals immediately close their shells, though destitute of eyes or ears.

The form of the shell is elliptic-oblong, 
with a contraction, or shallow notch as it were, about the middle of thcir outer margin. The man opened them by means of a whilk shell, which he thrust with violence between the valves, for it is impossible to effect this with the finger only. He introduced the point of the whilk in the centre of the base, or broader end, of the muscle, searching for the pearls chiefly towards the other end, on the inside of the valve. If the inside of the latter be white, the pearl is white; but if dark or reddish, the pearl is of the same colour.

When it was first discovered that this neighbourhood produced pearls, the river at Purkijaur was the place where the principal pearl-fishery was establishod. But now it is nearly exhausted. When the discovery of this bed of pearl muscles was first made, it is said the shells were in such abundance that nobody could reach the bottom of them, which is far from being the case at present.

There is no external sign about the shell, 
by which it is possible to know whether it contains a pearl or not. Consequently many thousands are destroyed to no purpose before one pearl is found. It is also a great pity that all the muscles are killed in consequence of this examination. Each pearl is either attached to the shell, or loose. They are found at all seasons of the year, and are sometimes thrown out of the shell spontaneously by its inhabitant.

I witnessed at this place what appeared to me a very extraordinary phænomenon, a pike in whose stomach, when opened, was found a young duck entire. The peasant who was my companion told me he had many times seen the same thing.

$$
\text { July } 27 .
$$

The reindeer fed with evident avidity on the great water Horsetail (Equisetum fluviutile), which the Laplanders call Aske, though it was in a dry state, and though they will not eat common hay. How unaccountably negligent are the Laplanders, 
not to collect in the course of summer at stock of this plant and of the Reindeer-moss (Liches rangiferinus) for winter fodder! They would then hare some provision for the herd, when the country is corered with an impenetrable crust of frozen snow, and not hazard the loss of all they are worth in the world.

The inhabitants of Westbothnia, to defend themselves against the bites of gnats, besmear theip skin with a mixture of tar and fish-grease, or some other kind of fat. They keep this composition in a horn which hangs at their side. The Liplanders however give themselves no trouble about any such matter.

In order to add to the pungency of the tobacco which they are in the habit of chewing, the Laplanders mix with it the root of Angelica. (A. Archangelica is preferred, but when that is not at hand, the sylvestris is used, as appears from the Flora Lapponica.)

The women wear their belts in the same 
manner as the men, except when they are big with child, in which case the belt must necessarily be placed much higher than ordinary.

This day I found the little heart-leaved Oplarys (O. cordata) growing, as it usually does, amongst the Rubus Chamcomorus, whilst I was gathering the fruit of the latter. Also the least Pinguicula ( $P$. villosa); but its leaves were withered, and the fruit was ripe, which is heartshaped and emarginate, of two valres and one cell. The last-mentioned plant grew among White-moss (Spllagnum palustre. These specimens are still preserred in the Linnan herbarium.)

The bird called (by the Swedes) Lappskata, Rödfogel in Westbothland, Grousach in Lapland, (Corrus infaustus, Fann. Succ. 32. Lath. Ind. 159. Ianius infuustue, Syst. Nat. r. 1. 138,) is of a small size, but it andaciously lays hold of any thing it can find, being so far from timid that it flew away with part of our prorisions as 
we sat at table. This bird seems nearly allied to the Jay (Corvus glandarius).

It is only in winter the clothes of the Laplanders have any sort of lining, except that these people generally wear, next the stomach, the skin of a young reindeer fawn. The sleeves of their coats are not fixed to the jacket, or body of the garment. The part which covers the shoulder folds over the top of the sleeve, in the shape of a wedge. A seam reaches the whole length of the jacket, from top to bottom, on each side, the jacket becoming gradually wider, downward. It reaches as low as the middle of the leg. The collar is for the most: part blue, stitched with white thread.

The reindeer are not slaughtered in the same manner as cattle usually are either at Stockholm or in Smoland. The animal being secured with a halter, the Laplander takes his spear and sticks it into the thorax behind the shoulder, so as to pierce the heart. By this means the blood collects in the carity of the thorax, none of it ap- 
pearing externally. After the skin is flayed off, the blood is found coagulated in the thorax, from whence it is extracted, and bruised into a soft mass. With this the poorer sort of people make a kind of soup, by boiling along with it the brains of the animal, which the rich do not eat. The testicles are nerer eaten by any sort of people. The penis serves to make a thong to draw the sledges.

Such of the Laplanders as inhabit the forests go to the alps at midsummer and return about St. Laurence's day (August 10th); and the mountain Laplanders descend into the lower country between the first of Norember and Christmas, and go back again about Lady-day.

All kinds of clothing made of skins are sewed with sinews of animals, as before described; but those of walmal cloth, with hempen thread purchased from the neighbouring countries. 


\section{July 28.}

'To-day I found the Pseudo-helleborine ; (possibly Cypripedium Calceolus, not before mentioned in this journal.)

All the little rills and rivulets hereabouts produced a Potamogeton, which I was doubtful whether to distinguish from the common lind, as it raries excessively in appearance, but the leares are more grassy. (P. gramincum, as appears from the Flora Lapponica, yet nothing can be less like the " common kind," if by the latter be meant the natans, which, with the perfoliatum and gramineum, compose the catalogue of species in $F$. Lapp.)

Hereabouts grew the Juncus with three seeds (capsules) at the top of the stem, which also I observed to be sometimes reflexed. (J.triglumis; sec Fl. Lapp.ed. 2. 90.)

Several days ago the forests had been set on fire by lightning, and the flames raged at this time with great riolence, owing to the drought of the scason. In many different places, perhaps in nine or ten that 
came under my notice, the devastation extended several miles' distance. I traversed a space three quarters of a mile in extent which was entirely burnt, so that Flora, instead of appearing in her gay and verdant attire, was in deep sable, a spectacle more abhorrent to my feelings than to see her clad in the white livery of winter, for this, though it destroys the herbage, leaves the roots in safety, which the fire does not. The fire was nearly extinguished in most of the spots we visited, except in ant-hills, and dry trumks of trees. After we had travelled about half a quarter of a mile across one of these scenes of desclation, the wind began to blow with rather more force than it had done, upon which a sudden noise arose in the half-burnt forest, such as I can only compare to what may be imagined among a large army attacked by an enemy. We knew not whither to turn our steps. The smoke would not suffer us to remain where we were, nor durst we turn back. It seemed best to basten forward, in hopes of VOL. II. 
speedily reaching the outskirts of the wood; but in this we were disappointed. We ran as fast as we could, in orcler to avoid being crushed by the falling trees, some of which threatened us every minute. Sometimes the fall of a huge trunk was so sudden, that we stood aghast, not knowing whither to turn to escape destruction, and throwing ourselves entirely on the protection of Providence. In one instance a large tree fell exactly between me and my guide, who walked not more than a fathom from me, but, thanks to God! we both escaped in safety. We were not a little rejoiced when this perilous adventure terminated, for we had felt all the while like a couple of outlaws, in momentary fear of surprise.

I hize long ago related my sufferings from gnats in the course of my Lapland expedition. In this place I was still more incommoded by some'very small flies, about a line in length and very narrow. Their breast was of a blueish grey. Front of the head whitish, with black eyes. Wings 
pellucid. Body greyish, oblong and narrow. A white scale was placed on each sicte at the insertion of the wings. The legs were black, with a white joint in the midale of each, the base being speckled. The hind part of the shoulders was whitish. Antenice simple, ninute, parallel, and pointing right forward. The wings lay one over the other so as to resemble a single one, notched at the extremity, when the insect was at rest. Each of us was beset by a whole legion of these flies towards sun-set. What rendered them peculiarly troublesome was their manner of running over the face, and flying into the nose, mouth and eyes. When they were approaching in order to inflict their bite, they were not to be driven away by our blowing ever so hard. The Laplanders call these insects Mockere, alluding to the smallness of their head; the Swedes Knott. (Culex reptans. Linnæus mentions in the Fauna Suecica the extremely tiresome noise made by these gnats in their approach.) They corered 
our linen so as to render it quite black. It was to no purpose to attempt to drive them away. (See v. 1. 208.)

I visited the Laxholms, islands so called from the salmon fishery. Here the Common Salmon (Salmo Salar, named Lax by the Swedes,) is found with the under jaw occasionally hooked, which variety is termed Kroklax, or Hooked Salmon. I inquired whether this hooked kind was esteemed a distinct species, or whether a difference arising from age; to both which questions I was answered in the negative. I was shown fish of the smallest size, which had in proportion as large a hook to the lower jaw as the largest. Bonge has therefore fallen into an crror in his dissertation upon salmon. (Daniel Bonge, Dissertatio de Salmomum natrira, eorumque apud Ostrobothmienses piscatione, Upsal. 1730. 4to. under the presidency of Professor Roberg, with wooden cuts.) I inquired whether the hooked salmon were furnished with roe or with milt. I was answercd that they 
had always milt. On opening seven of them I found this verified, whereas four salmon which were not hooked had all of them roes. The hooked (or male) salmon is so called, because the point of its lower jaw is bent inward, and has a taper form, resembling a finger; while on the contrary the upper is furnished with a cavity to receive that point, embracing it like a sheath, for about half its length. The female fish has a more obtuse luwer jaw, but not less inflexed, there being only a very slight furrow in the upper one; so that the two sexes may be distinguished from each other by these marks from the earliest age.

Those who fish for salmon come to this place about a fortnight before midsummer, and remain till St. Bartıolomew's day, August 24th, as during that space of time the salmon keep ascending the river. After the day last mentioned none of the fishermen remain. Few of the fish escape being taken, so as to return down the river. At Michaelmas the fishermen come here 
again, when they catch a smaller sort of salmon.

This day I observed the harrest beginning. The corn now cutting, though sown but a few days before midsummer, was nevertheless quite ripe. The lent rye was not yet ripe enough to be cut, but the winter rye ripens some time before the other corn. Thus it appears that corn (barley) springs up and ripens at this place in the space of sixty days.

In my walks I gathered the berries of the Strawberry-leaved Bramble (Rubus arcticus), which proved delicions. They have somewhat of the flavour of Blackberries (Rubus fruticosus), but are more agreeable. This fruit does not separate from its calys like other species of its genus. It is a compound berry, in size and structure somewhat between what the Smolanders call Kodden (Rubus saratilis), and Raspberries ( $R$. idceus). Its colour is a brownish crimson.

The (Pedicularis) Sceptrum Carolinum 
is perennial, with scales, not a fibrous tuft or beard, at the root*. The stem is round, not quadrangular. Calyx five-cleft 1 . Lower lip regular, divided into three equal segments.

Pedicularis with a purple head (Bartsia alpina. Linn. Sp. Pl. 839. Engl. Bot. t. 361. Eupluasia. Fl. Lapp. n. 246.) shows an affinity to the Crista Galli (Rhinuntluus) in its calyx, which is divided into four equal acute segments. The fruit is ovate and acute, compressed at the point. Lower lip straight. All the other Pediculares, except Sceptrum Carolinum, have an oblique fruit.

Here and there grew specimens of Heath (Evica vulgaris) with tufted branches, looking like a pruned spruce fir, and very. beautiful.

The water of the river now began to decresse, in consequence of which it became

* This account does not agree with the description in the Flora Lapponica, but is the most correct.

+ This also is correct. 
clearer, and it was more diflicult to catch any fisl.

Scarcely any species of Carex was to be found this season but what had some degree of smut or ustilago about its spikes, consisting of little globular black bodies, changing to dust.

\section{July 29.}

Tanning of leather is thus performed by the Laplanders.

The scaly cuticle of the birch being first stripped off, the bark is then scraped from the tree and boiled fresh in water, for about as long a time as is requisite to boil fish; being afterwards set by to cool, to a certain degree, that it may not injure the hide by being too hot. The latter, having previously been scalded, by dipping into lukewarm water, is then soaked in the decoction of bark, and the ressel containing it sunk into a hole dug in the ground, at the extremity of the hut. The hide is taken out every day, and softened in luke-warm 
water, till the hair becomes loose, when it is scraped off by such a knife as tanners use. The skin is then replaced in the tan when cool, without any previous drying, till the third day after the hair comes off, when it is hung up to dry in the shade. When the leather is but half dry, they often cut it up for shoes, which are always made by the women, without any last. The thread used for the purpose is that made of tendons.

Some persons never scald the hide, but scrape off the hair with a knife, soak it a little in water, and then plunge it into the tan.

Near Swartlär I noticed a mineral spring, but whatever may be its qualities, nobody has yet made any inquiries concerning them.

The river Lulea divides into two branches, not far above the bounds of Lapmark and Westbothnia, one of which is called the little river Lulea, whose origin is among the mountains towards Hyttan, the other 
Stor Lulea, runing from the alps in Norbattra.

$$
\text { July } 30 .
$$

On examining the cultivated Hop (Humulus Lupulus), I found the structure of the female as follows. Calyx consisting of an universal involucrum of four leaves, and a partial one, likewise of four ovate leaves, containing eight florets, each of which has an ovate spatha, of a very large size with respect to the rudiments of the fruit. Petals none. Pistils two, horn-like. Stigmas acute. Seed-vessel none, the base of the spatha enclosing the seed, which is solitary.

The shore of the river Lulea produced, in excessive abundance, the Water Sedum (Tillce aquatica); likewise the Aquatic Dwarl Plantain (Limosella aquatica). The Spiked Water-grass, with a bent stem, here grew abore other plants, twisting its leares round them, like a sort of bindweed. (Alopecurus geniculatus $\beta . S p . P l .89$. See Fl. Lapp. n. 38.) 
The Water Sechm (Tillar aquatica) proved no less plentiful by the sides of the roads.

In the river I gathered an herb, which I was doubtful whether to reler to Stellaria (Callitriche), to Potumogeton, or to the Aponogeton of Pontedera. (This appears to have been the latter, Zumichellia palustris.)

I reached the old town of Lulea in the evening.

It rained and thundered riolently during the whole night.

\section{July 31.}

This day I harl intended to prosecute my journey towards Tornea, but a heavy rain, with tremendous thunder and lightning, confined me entirely to the house.

The wife of the principal clergyman of Lulea, on whose accuracy I have the greatest possible dependance, assured me that she had, at the posthouse of Biorsio, in the parish of Torp, in Medelpad, seen large quantities of the Yellow Aconite (Aconitum 
lycoctonum; see rol. 1. 36), collected and boiled for the use of the table, like cabbagre. This astonished her very much, as she knew it to be used in Jemtland to poison flies. When she expressed her apprehensions about eating of this herb, the maidservant laughed at her, telling her it was much too good to he so slighted.

Hares are always hunted in this part of the country, and the dogs are trained not to bark. If they offend in this respect they are sure of a beating.

\section{August 1.}

I found some Truffes (Lycoperdon Tuber) between Herten and Swartli.

Near the road grew Glaux (maritima), as well as the Narrow-leaved Sea Plantain (Plantago maritima), and Small-leaved Angelica (A. sylvestris). On a bank I observed Triticum maritimum. (This last is thought by Dr. Afzelius to be Elymlis arenarius. See Fl. Lapp.cd.2. n. 34.)

Here various plants, which I had found 
blossoming at Umoa, were now laden with fruit, as the Mesomora (Cormus suecica), Vaccinia (Whortle-beries), Chamcmorus (Rubus Chancemorus, Cloud-berry), and Chancerubus (R. saxatilis, Stone Bramble), all which vied with each other in the profusion of their berries. But little Ling (Erica) was to be seen.

The hills are but trifling. Rising grounds, which had partly been burnt, were covered with Spruce firs, and even with Reindeermoss (Lichen rangiferimus).

Towards evening I arrived at Tornea. The weather was fine.

Near Grotnäs, situated opposite to the church of Calix, is a ferry to convey passengers to this church, adjoining to which the inhabitants of Lulea and Tornea keep a fair.

The river produces abundance of Flotegrass, which at this time bore its spikes or heads of flowers. I had long been acquainted with the plant, it being very abundant in this country as well as in Smoland, and 
had wondered what species it could be; especially as I nerer heard of any botanist who had met with the fructification. It is a Sparganium, whose leares are very long, reaching a fathom or two according to the depth of the water, and floating on its surface. They are convex at their back, except in the lower part, which is lat on hoth sides. (This plant named lotagres, or Flote-grass, in Linnaxus's native country of Smoland, is the Sparganim n. 34.5* of Fl. Tapp. in the second edition of which work I have called it $S$. nuterns, on his own authority in the Flore Suevica and Species Plantarum; but in English Botany, v. 4. 273, and Fl. Bril. 962, this error is corrected, so far at least as concerns the original Lapland specimen, which is unquestionably S. simplex, Engl. Bot. v. 11. t. 745, a species he aid not, in his works, distinguish from our common S. ranosum, t.744. I am now persurded he confounded this simpler with the natans in his Lapland tour, as well as in his herbarium, 
where the original specimens of the two aro pinned together.)

\section{August 2.}

They dry their corn upon drying sheds as is practised in Smoland. The cross piece is turned towards the south, but the method here differs from that of the Smolanders in one respect. The latter place one sheaf on the top of another, but the inhabitants of IVestbothnia lay the sheaves crosswise, in an alternate order, each thinking their own method the best for procuring the most complete ventilation. In this country fifteen sheaves are lodged under each shed, without supporters; but in Smoland twelve only, ten of which are in the main pile and two at the sides. The Smolanders therefore are able to reach high enough to place their uppermost sheaves by hand, but the inhabitants of Westbothnia find it necessary to be provided with what they term a Skyllkrok, or Rick-hook, consisting of a round pole, with a transverse 
projecting piece of wood, (like a directionpost in England, as appears by the sketclk in the manuscript,) by means of which each sheaf is lifted up.

On a heath very nea. the river Sangis I noticed some earth of a red colour. The dry part of the forest which had becn burnt down, produced Reindeer-moss (Lichen rangiferinus) in such abundance, that the whole face of the ground was covered with. it.

The evening was fine when I reached Zangis (or Sangis), where I took leare of my native tongue.

\section{August 3.}

At sun-rise the marshes were all white with hoar frost. In the preceding night winter had paid bis first visit, and slept in the lap of the lovely Flora. I did not observe that she had suffered from her rude visitor, except with regard to the Dracontium (Culla palustris), the leaves of which assumed a pallid aspect. The plants latest 
in bloom at this place, are Erica (vulgavis), the Red-flowered Persicaria (Polygomum Persicaria), and Hieracium premorsum (Leontodon autumnale, Sp. Pl. 1123. Hedypnois autumnalis, $\mathrm{Fl}$. Brit. 826. Engl. Bot.t. 830.)

On leaving Sangis, I left my mothertongue behind me. At Saris I met with native Finlanders only, whose language was unintelligible to me.

Here grew the Masarooth (Selinum palustre) with a proliferous umbel.

The mouse-traps used here are made like those for catching squirrels; which I have already described.

Between Zeivis (perliaps Saris) and Tornea are three ferries to pass. In my way I noticed a new species of Stellaria (Callitriche), of a small size, not leafy at the top, erect, not creeping like the S. minor; (see Fl. Lapp. n. 2. var. $\gamma$.) It had the appearance of Potamogeton graminifolium (gramineum). (What particular state or appearance of the Callitriche this might be, VOI. II. 
does not appear, nor is it mentioned in $F$. Lapp.)

I reached Tornea by three o'clock.

\section{TORNEA. \\ August 4.}

A reindeer may be driven in a carriage twelve (Swedish) miles in a day, or, at the utmost, fifteen; but the animal is generally killed immediately afterwards with the Laplanders' spears, and eaten.

The Laplanders are perhaps so called from the (Swedish) word lappa, to sew or patch together, because their garments usually answer to that description.

The degree of cold is certainly greater on the alps than in less elevated regions; for instance, it is colder in Jamtland than at Tornea, though the former lies about one hundred miles further south. Thus it appears that the cause of the severity of the cold does not depend so much on the approach towards the pole, as on the ele- 
vation of the ground, which ought to be carefully observed. Hence the plants of the north of Lapland are such only as are capable of resisting the most serere and long-continued co!d, and hence snow lies on the alps of Italy:

Alpine plants are, for the most part, perennial, except the Little Blue Centaury (Gentiana nivalis), and perhaps the Singleflowered Lychnis (apctala). I wish botanists would endeavour to discover and make known any new kinds of pulse or grain, especially such as are of a hardy constitution, and not likely to suffer from the severity of winter. Some are perhaps to be found among the grasses. It is necessary to ascertain what degree of northern latitude they would bear, and whether they are capable of growing within the frigid zone. It is worthy of inquiry in what respects the Alps, properly so called (of Switzerland,) agree with ours of Lapland, as well as how far, and by what means, they are susceptible of culture. The descriptions 
that have been given of them may be consulted. The Greenland alps would also be worth examining, to see how far these different countries agree in their native plants, in varieties of situation, and in plenty of soil, compared with the proportion of rocks or large stones. Do they all agree in the diminutive stature of their plants?

The tranquil existence of the Laplanders answers to Ovid's description of the golden age, and to the pastoral state as depicted by Virgil. It recalls the remembrance of the patriarchal life, and the poetical descriptions of the Elysian fields.

So many Finlanders crowded about me, that I scarcely knew what to do. They were all blear-eyed to such a degree as to be nearly blind. Many of them were perfectly deprived of sight, and ninety-nine out of a hundred that were so had their eyes shut. It seems in vain to prescribe. any remedy for this evil, so long as its cause is every where so prevalent. This consists in their smoky dwellings. If I had 
the management of these Finlanders, I rould tie them up to the wall and give them fifteen pair of lashes apiece till they made chimneys to their huts, especially as they hare such plenty of fire-wood. This improvement in the comfort of their dwellings might surely be accomplished by the authority of the chief magistrate, for I have not been able to learn any sufficient reason for their adherence to their old way of building. If people thirty or forty years of age are thus afflicted, what must become of them by the time they are serenty?

The Finlander's scythe is represented in the annexcd figure.

The handle is rather above two fect in length, straight for about the space of a foot from the part where the blade is bound on. Afterwards it is slightly curred outwards, and then again, towards the apex, in some degree inwards, so as to make a straight line with the base. The top is thicker than any other part. The blade of the scythe is, like that used in our 
134

TORNEA:

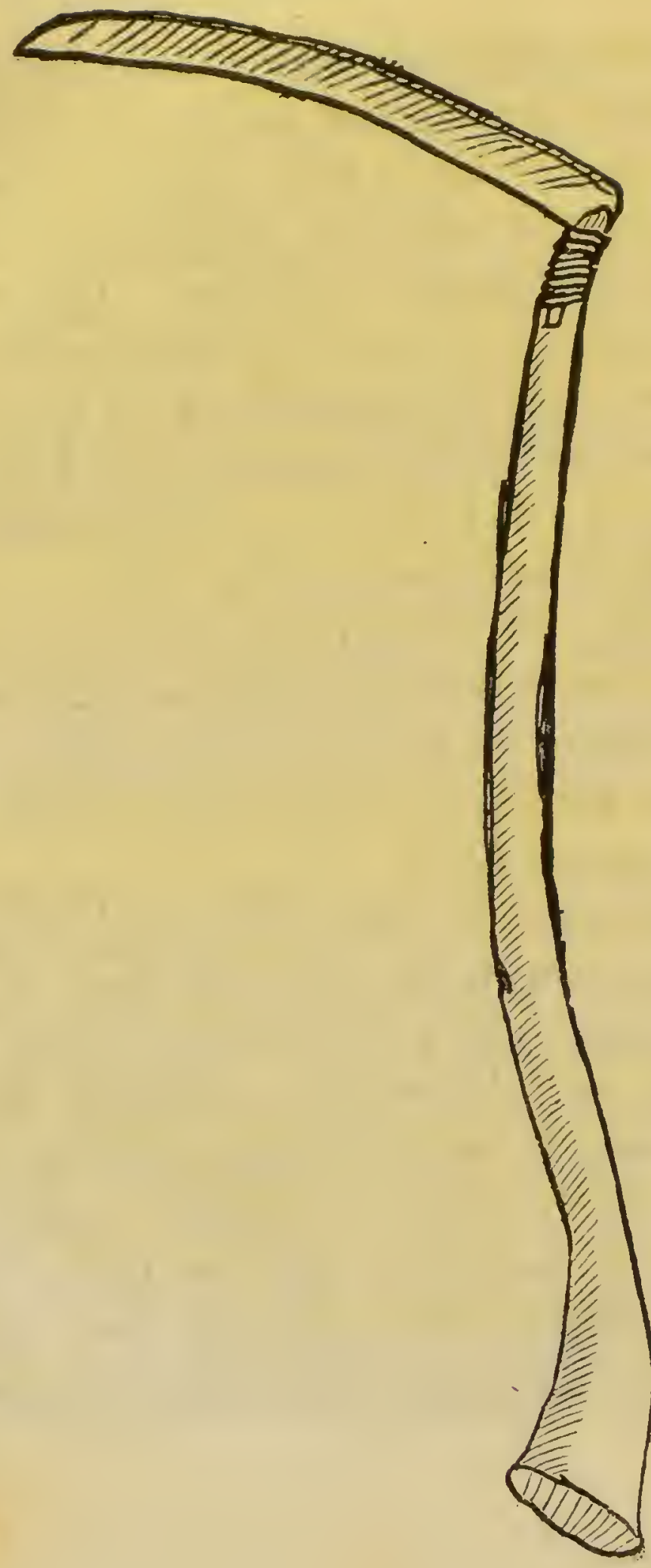


country, about a foot and a half long, and an inch and half broad, very slightly curved. Its back is, like that of our scy thes, thickened on one side. The mower takes hold of the top with his left hand, so that the back of the scythe is uppermost, but grasps with his right the part where the above-described curvature ends, so as to be able to give the edge a turn upwards. As he moves forward, he mows first on the right, and then on the left, only turning his hands, and not lifting the scythe, but merely presenting each side of its blade alternately to the ground.

On the south-west side of the town, across a small bay, lies a mineral spring. The water is not ill-tasted. Indeed this is one of the best mineral waters I have met with in the north; but it lies very low, appearing to derive its origin from a stream that runs above, so that its water comes out soiled, as it were, from the earth, and is covered with scum. 


\section{August 5.}

Every body at Tornea was continually talking to me of a distemper to which their horned cattle are subject, and which kills many of them in the course of the winter; but especially in the spring, when they lose from fifty to a hundred head of cattle almost every year. On walking to examine the meadow into which they are first turned out to grass, I found it a bog or marsh; where the Water Hemlock, Cicuta aquatica, (C. virosa, Sp. Pl. 366. Fl. Lapp: n. 103. Engl. Bot. t. 479.) grew in abundance, and had evidently been cropped plentifully by the animals in feeding. It seemed probable therefore that they eat if most in the spring, when first turned into this pasture; whence it proves so much more extensively fatal than in summer; when perhaps they only pick up a plant here and there. It grows in all the moist meadows which are nown for hay; conse- 
quently the cattle take it likewise in their winter food, and therefore perish, more or less, during that time of the year. We learn from Wepfer's experiments, who gave. it to various kinds of animals, what violent symptoms it occasions. See his book. Nothing appeared to me so interesting, during my risit to Tornea, as to examine into the cause and remedy of this evil. If my ideas be right, the whole might be prevented by employing a woman for a month to eradicate all the Cicuta; by which this town, small as it is, might save above two hundred silver dollars. I was informed that the cattle dying from this cause become so infectious, that they cannot be flayed without great danger. The persons employed in that business have their hands greatly. swelled by touching the carcase, and several have lost their lives in consequence. The plant in question, therefore, agrees in qualities with the CEnanthe, as it does likewise in place of growth and outward ap- 
pearance, especially in the pinnce of its leaves.

* A few further remarks on the above subject, printed in the Flor Lapponica, may be acceptable to the English reader.

"This disease made no regular progress, nor was it communicated by infection from one animal to another. The cows arc driven all together in the spring to feed in a meadow, near the town, to the southwest, on the other side of a creek of the river, in which I was informed the greatest mortality happened. The symptoms differ in different cases; but all thc cattle, feeding indiscriminately, are seizcd with a swelling of the abdomen, attended with convulsions, and die with horrid bellowing, in the space of a few days. No person dares venturc to flay the recent carcases, it having been found by experience that not only the hands, but even the face, in consequence of the warm steams from the body, became inflamed and gangrenous, and that death finally ensued.

"I was asked whether this disease was a kind of plague; whether the meadow in question produced any venomous spiders; or whether the yellow-coloured water was poisonous.

"That it was no plague appeared from its not being contagious, and from the spring bcing its most fatal season. I saw no spiders here, except what are common throughout all Sweden; nor was the yellow 
The meadows hereabouts, among the thickets towards the shore of the bay, afforded me the following plants.

1. Veromica (muritima), with an erect stem, branched in the upper part, and sediment of the water any thing more than a common innocent nchre of iron.

"I had seareely landed from the boat in which I was taken to this meadow, than the Cicuta presented itself before me, and explained the cause of all this destruction. It is most abundant in the meadow where the cattle are frst seized with the distemper, especially near the shore. The slightest observation teaches us that brute animals distinguish, by natural instinct, stich plants as are wholesome to them, from such as are poisonous. The cartle therefore do not eat this Hemlock in summer or autumn; whence few of them perish at those seasons, and such only as devour the herb in question incautiously, or from an inordinate appetite. But when they are first turned out in the spring, partly from their eagerness for fresh herbage, partly from their long fasting and starvation, they seize with avidity whatever comes within their reach. The herbage is then but short, and insuffieient to satisfy them; probably also it is in general more sueculent, immersed under water, and scarcely perceptibly scented; so that they are unable to distinguish the wholesome from the pernieious kinds. I remarked 
bearing numerous spikes. Lower leares acute, cordate-oblong, sharply serrated, the upper ones lanceolate, serrated, two, three, or four together, opposite on the stalk. Corolla tubular, divided two thirds of its length into two lips, of which the upper is the broadest, ovate, obtuse, and nearly erect; the lower three-cleft, the middle segment narrowest, but all of equal length. Stamèn's two, very long, awlshaped, situated at the separation of the two lips. Hence the flower is of the personate kind. Pistil reflexed. Capsule heartshaped, narrow at the upper edge. The flowcrs are numerous in each spikc.

2. Selleri, (Apium graveolens*) unless

every where that the radical leaves only were cropped, no others; which confirmed what I have asserted. In a neighbouring meadow I saw this same plant cut with the hay for winter food; so that it is no wonder if in that state some, even of the more catutious cattle, are destroycd by it." Fl. Lapp.ed. 2: 76.

* This plant is not mentioned in the Flora Lapponica, and the account annexed seems to belong to Ligusticum scoticum, 11. 107 of that work, with which it well agrees. 
I ain much mistaken. The petals are white, spreading, and acute. The partial umbels are broad. The general one has very rarely one or two (leares of an inrolucrum?).

3. Galium parisiense (uliginosum), with a square, furrowed, procumbent stem. The leaves are lanceolate, broader towards the extremity, acute, armed with little prickles as well as the stem. The flower is not tubular, nor the seed.s prickly. The latter are white, as is also the flower. Four leaves grow together in the lower part of the stem, but in the upper part six. Under the little umbels of flowers are either four or two.

4. Galium album (boreale). Stem square, erect, branched, especially in the upper part. Leares four together, sessile, rather broader towards their base, three-nerved, slightly reflexed at the margin. There are two leaves to each of the lesser umbels. Seeds two, roundish, joined into a didymous shape, downy. Flower not tubular.

5. Cruciata, if I am not mistaken. ( $G a-$ 
Iium palustre, that is, Cruciata palustris alba of Tournefort.) Leaves four, ovateoblong, bluntish, narrower towards their base. Flower, I believe, not tubular. Sec what I gathered in the woody parts of Lulean Lapland. (This was the same species, as appears by the $F l$. Lappr.)

6. Clymenum parisiense (Latluyrus palustris). Stem triangular, two of its angles ending in wings, or having a dilated compressed border. There are two little oblong pointed angular leaflets at the insertion of the leaves, which latter are pinnated, ending in a tendril, and composed of two or three pair of nearly lanceolate pimno. The flowers are violet-coloured, three or four on each common stalk.

7. Angelica temifolia (sylvestris), which I would define $A$. umbellulis globosis. The general umbel, though often naked, is commonly furnished with one, two, or as fur as five, very slender leaves; each partial one has often as many as eight. It is curous that when the plant blooms vigorously, 
none of the stalks of the umbel can be seen, but the flowers form a complete ball, like the Double Guelder-rose (Sambucus Opuhus, flore pleno,) or the Globe 'Thistle (Echinops Sphcrocephahus). The petals are lanceolate and spreading. Stem striated, or slightly furrowed.

8. Cicuta aquatica of Wepfer (C. virosa above mentioned). I am disposed to refer this plant to Enanthe, on account of its external aspect, which is wonderfully like the last-mentioned genus. I must examine whether their flowers agree. The footstalks are hollow, inflated, and erect. Pinnce three, rarely four, pair, of a narrow lanceolate shape. Those on the stem have from three to seven serratures each, but the radical ones have more, all distinct; and sometimes the lowermost serrature, at the lower edge, grows out into a sort of spurious pinnula. The top of the stem bears from one to three umbels; the general umbel being naked, or rarely furnished with a solitary 
leaflet*. The partial ones have seven short, narrow, acute lcaflets. The tips of the petals are inflexed.

9. (Pedicularis) Sceptrum Carolinum. Its capsules are rose-coloured, its flowers yellowish white tipped with flesh-colour, and obtuse. The capsules are about equal to the interstices of the spike, which all together is about four inches long.

\section{August 6.}

The day of the holy sabbath, and therefore a day of recreation for both mind and body. I saw in the church (of Tornea) a memorial of King Charles the XIth's own observation of the sun on the 14th of June, 1694. The sun was visible on that night till very near twelve, when a small cloud hid it from the sight. It was however above

* Linnæus in this description denominates these leaflets, whether of the general or partial involucrum, radii, a term he always subsequently used for the stalks of the umbels. 
the horizon*. In winter the sun does not rise above the horizon, but at the solstice it becomes visible. Could it be seen from the pole?

The young women in Finland have much more swelling bosons than those of Lapland; the latter accord best with the description of the poet,

"Quales cruda viro puella servat."

(Marl. lib. 8. ep. 63.)

* King Charles the Eleventh, on his visit to Tornea in 1694 , was accompanied by Count G. Douglas the Lord Licutenant, Count Piper Counsellor of Chancery, J. Hoghusen Counsellor of the Board of War, and some other learned men, and in the night between the 13 th and 14 th of June saw, from the belfry of the church, the midnight sun, at that time visible there to a person placed on such an elevation. The year following, Professors Bilberg and Spoie were sent to Tornea to repeat these observations. The royal visit to Tornea was commemorated by a medal struck on the occasion, having on one side the bust of the king; on the rcverse, a represcntation of the sun half above the horizon, with this motto, Soli inocciduo Sol obvius alter ; and beneath, Iter Regis ad Botniam Occidentalem, Mense Junio 1694.

VOL. II. 


\section{August 7.}

The town of Tornea stands on a small island, inhabited close to the shore on the south-west side. I call it an island, because it is bounded on the north by a swamp; on the south-east by the great river of Tornea; on the west and south-west by an arm of the sea, like a large river in appearance, but so shallow that no vessel can approach within a mile of the town on that side. This arm of the sea was formerly the ling's road, (a channel obliged to be kept open,) but now it is almost dry in summer time, on the north side, towards the swamp.

I ascended the steeple from whence his majesty king Charles the Eleventh saw the sun at midnight on the 14th of June, 1694.

\section{August 8.}

Nothing worth notice occurred.

$$
\text { August } 9 .
$$

Learing Tornea, I proceeded to Kimi, 
where is a large salmon fishery, for which this place is remarkable, as Liminge is for its meadows, and Storlionis for its cornfields, hut the last yield the greatest profit.

\section{August 10.}

I stayed at the house of the principal clergyman in Kimi till the 11 th. 'This day I gathered a sort of Pink, Caryophyllus, with reflexed petals of a purplish colour, divided into many segments almost to their base. 'The claws, not contracted at the summit, bear on the upper side, at the bend, a tuft of dull-coloured hairs. (This was the beantiful and fragrant Dianthus superbus.) Also a Salix with appendages at the base of its leares. (What species this was, does not appear.) At the shore of the great river grew Alsine repens, foliis gramineis, (Stellaria uliginosa, Fl. Brit. 476. Engl. Bot. t. 1074.)

Lying-in women at this place are accustomed to drink brandy seasoned with pepper, partly for the sake of its intoxicatL 2 
ing quality, by way of a narcotic, and partly to bring on the labour pains. The clergyman's wife told me an infallible method, as she said, to prevent the pains which often follow childbirth. When the woman's first child is born, and the umbilical cord divided, a spoonful of the blood is given her to swallow. This is to be practised at every succeeding labour, and I was assured that each would be rendered more easy, without any after pains.

In East Bothnia, as well as in Medelpad, it is customary to have the dairy superintended by a superior female servant, called the fäbodar, who receives for each cow one pound of butter and one of cheese, besides a pound of mesosmör. (See v. 1. 197.)

To obtain a greater quantity of butter, the milk is set by, either in a cellar or in a double-walled house, to be kept as cold as possible, for at least two days, or so long as that it will not stick to the finger. The milk will not turn sour, but will become very thin and blue, while the cream 
collects on the top, of considerable thickness and in great perfection. The cream being taken off, and put into the churn, often proves so rich, that after it has been chumed but a short time, if the churn be laid on one side nothing will run out. It is no small labour to churn such cream.

Of the remaining milk cheese is nade, being warmed before it is congulated. If the milk has begun to turn sour, it will not do for this purpose. Such thin milk as this is not very fit for eating, but the whey which scparates from it in the making of cheese, is by some people made into syru. (See v. 1. 243. 2.11 .) This is done merely by putting it, when cool, into a vessel or cask, when, if set by for a considerable time, it will become extremely tough. Miost usually however it is boiled, and then liept for two or thrce days, when, some new milk being added, it is boiled up again to the consistence of fummery, and then set by in some lind of ressel. If it remains for a long while without being touched, it 
grows hard, and becomes mesosmör. (v. 1. 243. n. 12.) The blue milk above mentioned may be boiled like fresh milk, and does not readily turn sour.

Cios-myolk, or rather Gäs-mjölk, (from the Swedish verb giasa, to work or ferment, ) is marle as follows. The butter-milk is set by in a tub till it begins to ferment, when about a third or fourth part of the quantity of fresh milk is added, the whole being allowed to work once more. A serum by this time is formed at the bottom, which is drawn off by means of a cock or tap, in the bottom of the tub, and used immediately for food. A similar portion of fresh milk is then put to the remaindes, when more whey is, in due time, deposited. This practice is repeated from time to time for the space of a fortnight, at the end of which the milk in the tub becomes of a thick consistence, and is excellent eating.

Servet-möilk (Napkin Milk) is made by taking a quantity of sour milk just beginning to ferment, when bubbles, like hy- 
datids as it were, are formerl between the cream and the milk. This is cut across in rarious directions, and the thicker substance taken off and hung up in a napkin, that the liquid part may drain away. What remains in the napkin acquires a firm consistence, and is eaten along with fresh sweet cream.

\section{EAST BOTHLAND.}

\section{August 11.}

I departed from the house of the chief clergyman of Kimi, whose name is Forbus or Forbers, and that of his wife Christian.

Here I ubserved the Lumme of Wormius, (Colymbus arcticus; see v. 1. 27.) Its outermost toes were largest, and most naked; the next, or middlemost, smaller; the thumb, or innermost, very small.

A skin of a squirrel, that had been caught in winter, was white towards the end of the rump, as were also the outermost toes, and the ears. 
In my journey this day I met with the Stratiotes (uloides), and the Butomus (umbellatus); as well as the Mesomora (Cormus suecica), the spotted Palma Christi (Orchis maculata), and the Gnidium. (Thislast could be no other than the Mezereon, Daphne Mezereum, formerly called Coccognidium.)

I found also the Ladies' Slipper (Cypripedium Calceolus), but it was almost out of flower.

The calyx consists of four long, coloured, lanceolate leaves, two of which, the upper and lower, are longer and broader than the two lateral ones. Petals two, the uppermost inversely ovate, reflexed, bearing the anthers. Is it the pistil? The lowermost inflated, obtuse, about an inch long. Anthers two. Fruit below the flower, of one cell, oval, with three principal and three smaller angles, splitting laterally into three valves, having a central column between them. The seeds adhere longitudinally to the middle of the placenta (or 
receptacle). The herb has the aspect of Veratrum.

\section{Aligust 12.}

The forests hereabouts are composed of Birch and Spruce fir mised with Pine (Pinus sylvestris), and a little Juniper (Juniperus communis). The herbaceous plants grow luxuriantly in these woods, and attain a remarkable height. Berries of the Wild Vine (Rubus saxatilis), the Vaccinium (Whortleberry), Mesomora (Cormus suecica), Empetrum (Crow or Crake-berry), and (Rubus) Chancmorus, are here in abundance. The (Pedicularis) Sceptrum Carolimum presents itself erery where in the highway.

The pales, with which the fields are fenced off, are placed horizontally against upright posts.

'The houses, or rather smoke-huts, are called Pyrter in this part of the country. In these there is no proper fire-place, but the whole is an oven, as it were, consisting of the four walls of the house, with a flat 
cieling. In the latter is a hole by way of chimmey, but not partially corered by any kind of licl, or trap-door, as in Norway, (see vol. 1. 357,) so that when the fire, made on a hearth under this opening, is rery smoky, it might be entirely opened to let out the smoke. There is indeed a sort of wooden window in the roof, but it is rarely opened. The people think themselves the warmer because the smoke can escape by the door only, and are persuaded that they should be frozen to death if they had a chimney; which opinion seems to me altogether absurd. Would it not be better to have chimneys, with a moderate degree of warmth, than a heat like that of a bagnio, with blind and sore eyes, and a black sooty house? They lie on the floor in the midst of this smoke, and that is their only bed. Notwithstanding their opinion, I cannot help thinking that full as much cold air enters by the door, as there could by a chimney. They are so anxious to keep themselves warm, that they do not 
venture to have any windows, only shutters in their stead; indeed they seem to be as fond of darkness as owls. I peeped into one of these houses through a shutter, and within was perfect darkness. Nevertheless there were several children and other persons in the dwelling. I could distinguish nothing but what seemed to me a pair of glaring fiery eyes, like the devil, in a sort of large jug. On looking more attentively, I perceired that the object before me was actually a jug or pot, in which I had already remarked that they were accustomed to carry lighted ember's, when wanted, to their neighbours.

I am sure the peasants of Smoland often make a fire sufficient to roast them alive, though their houses are furnished with chimneys, and their fres are made, as at this place, with small pieces of wood. To say the truth, fer persons can be of opinion that such excessive heat, in the winter of this very severe climate, can be wholesome.

I have already mentioned that the inha- 
bitants of these smoky dwellings have no beds, but actually sleep on the floor. In the summer season, howerer, they generally sleep in their barns. Round the inside of the above-described hut or cottage, are ranged various tubs or wooden ressels. In one corner, opposite to the spot where the fire is made, stands a table.

As it would be impossible to bear a fire in these dwellings during the heats of summer, their owners have another building which serves them for a kitchen. This is almost of the shape of the Laplanders' huts, but double their width and height, consisting of cloven beams or posts, such as are used for the fences of the fields, only not covered in, like the awcllings of the Liplanders. In the centre, where all the posts meet at the top, the pot is suspended over the fire. Here they boil their provisions, distil brandy, \&c.

The stage-houses* are constructed lilie those seen at some posthouses in our part

* Stegerhusen. I have not been able to make out the precise meaning of this word. 
of the country, having the centre of the roof raised on longitudinal timbers. They are loity, but narrow. The wooden walls curve outwards towards the top.

This year the crops of corn proved very bad in this neighbourhood, so that the inhabitants were obliged to chop their chaff, with the upper part of the straw, as finc as possible, of which, when ground, they made bread. Others preferred the bark of Pine-trees (Pinus sylvestris) for this purpose. The fields of rye, sown in the autumn, were at this time quite green. The winter rye, sown last year, was not yet cut. The sheaves are not laid upon any stage, or under any cover, but are placed ten together in a heap, standing nearly upright, the uppermost sheaf bcing laid across, so as to shelter the others. They are afterwards carried into the lilns, which at this place have exactly the appearance of bagnios, with ovens built of boulder stones.

The fastenings of the doors are quite dif- 
ferent here from those used in Smoland, which are fixed into the floor, and capable of being raised or depressed at pleasure. The fastening here is a kind of long button upon the door, on the side where the hinges are fixed, which being turned horizontally over the door-post, prevents the opening of the door.

By the road side grew an Amanita (Agaric) with a stalk two inches high, and as thick as a goose-quill. Its head was hemispherical; pale above; concave beneath, with loose gills. (Probably Agaricus n. 499. Fl. Lapp. ed. ․ 373. Fl. Sliec. n. 1217. ed. 2.446.)

The scythes used in this country nearly resemble those of the Norwegiains, but differ in this respect, that the upper projection from the handle stands out horizontally, see figure e, b, while the lower, c, is perpendicular, and the top, a, which rests against the arm, is flattened. The mower is therefore obliged to take hold of the foremost projection, with his left hand, 
EAST BOTHLAND.

159

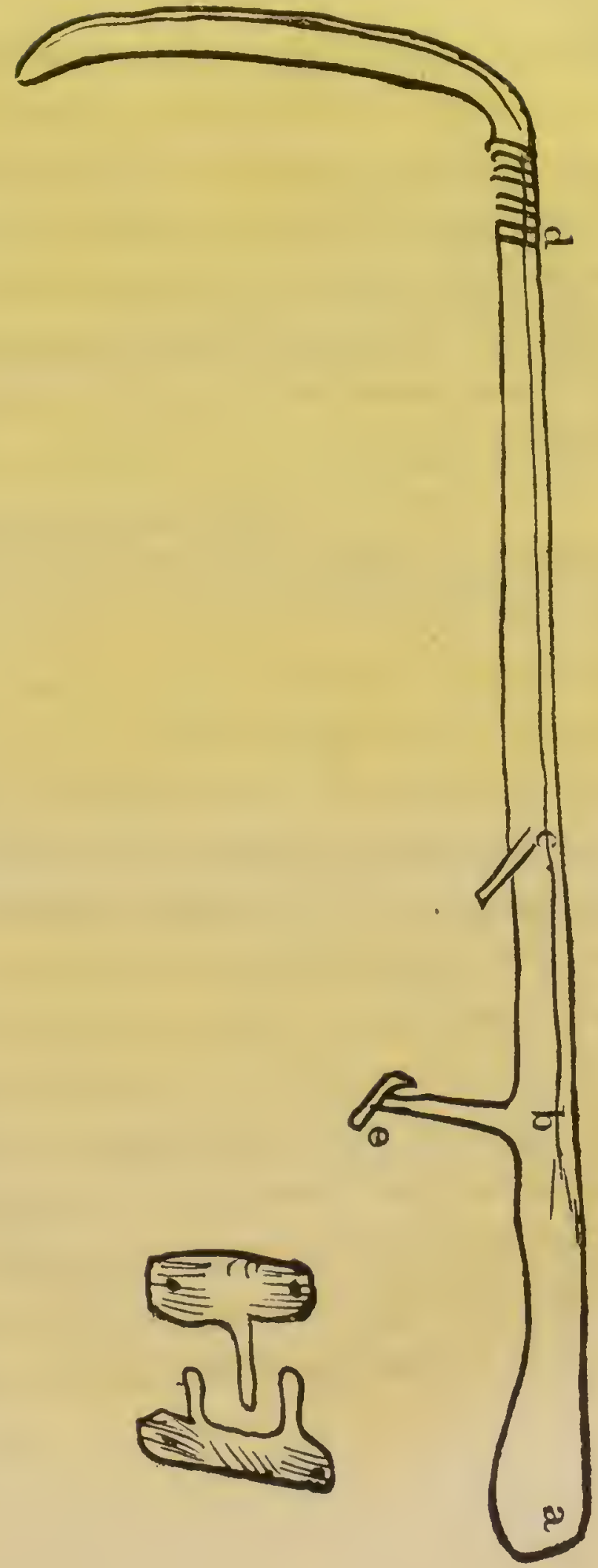


under the main handle. The advantage of this is, that he is able to move forward in a nearly upright posture. The Norwegian however walks still more erect in mowing. The proportions of this Kimi scythe are as follows: From a to $\mathrm{b}$ one foot and a half; $\mathrm{b}$ to $\mathrm{c}$ two palms and a half; $\mathrm{c}$ to $\mathrm{d}$ two feet; the breadth at $b$ two inches in a right line. The length of the projection $\mathrm{b}$ is three inches; and of $\mathrm{c}$ the same. The blade is like our Smoland ones, but stands at an acute angle with the handle.

The harrow consists of four or five links, in each of which are twelve joints. These have alternately one and two projecting pieces each. (See the figure annexed to the scy the just described, p. 159)

In the stage-houses (see p. 156,) boilers are fixed in the walls, for boiling horsedung, which is given as food to the cattle; as well as to heat water for pouring on reindeer moss (Lichen rangiferimus), which is also used for the same purpose; but such diet gives a loathsome taste to their milk. 
In the roof of these houses hams and salmon are smoke-dried.

During the winter the people are obliged to work in their miserable cabins or Pyrter, when they open their shutters; but nevertheless find themselves sufficiently warm.

The annexed cut represents a sort of plough, used at Kimi.

a, the base, is three palms long and one broad.

$\mathrm{b}, \mathrm{b}$, handles, each a palm in length.

c, d, shafts, six feet long, and of a round figure.

$e, e$, chains by which the shafts are attached to the collar or yoke. The distance betwixt $e$ and $e$ is three feet.

$f, f$, a straight or flat cross bandage. $\mathrm{g}, \mathrm{m}$, the base of the plough-share, three feet in length, and two palms and a half broad.

$h, h$, points of the share, five palms long; distant at their base one foot three inches, at their extremities two feet.

YOL. II. 


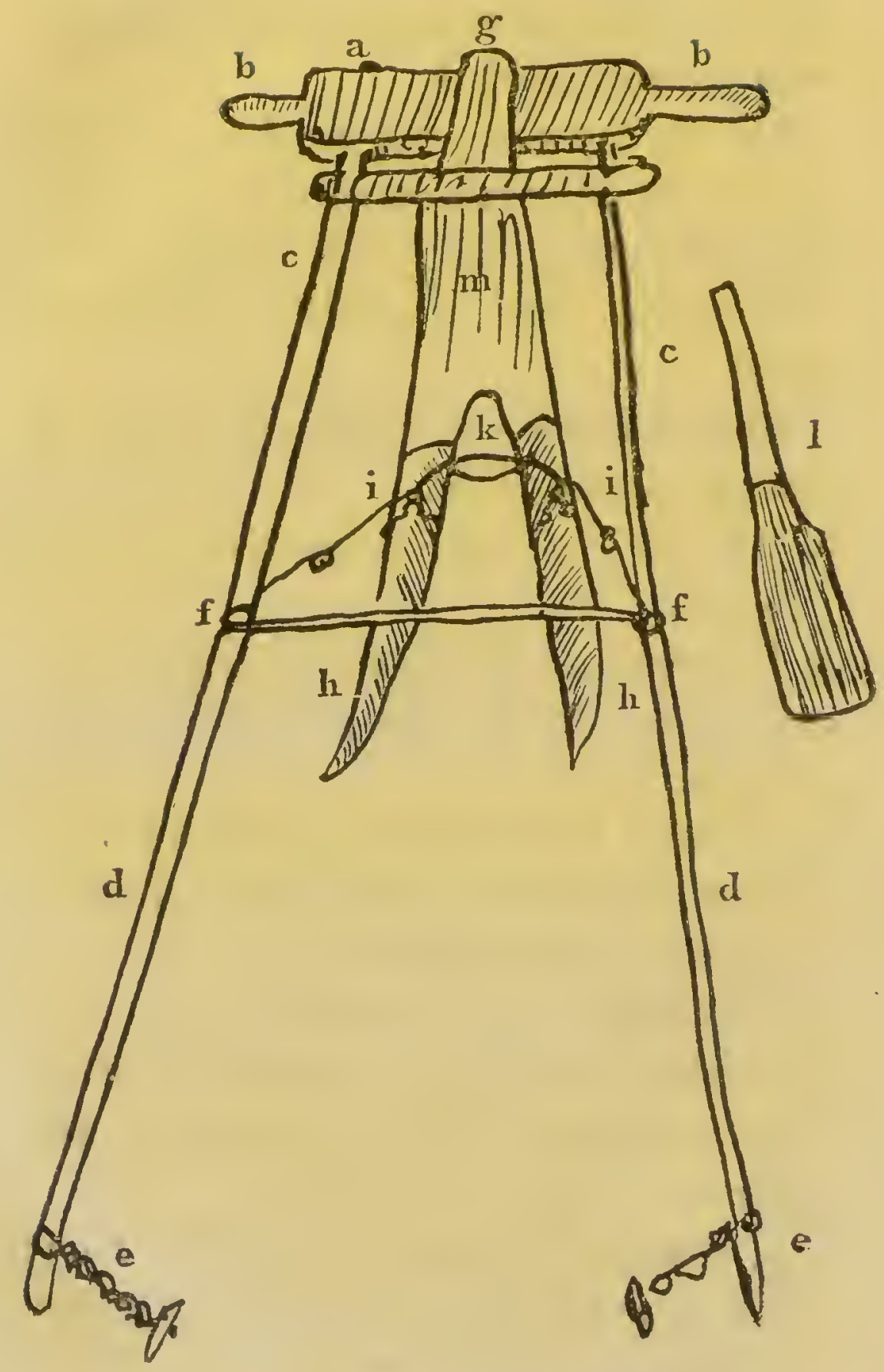


$i$, a chain of long links, fastened to a ring that embraces the base of each point of the share, into which chain, at $k$, is introduced the handle 1 ; this acts so as to bring the points together rather than to separate them.

It must be observed that the inner edge of these points is turned downward, so that when the handle or spatula 1 is put in at $k$, and is laid upon one of them, the earth is thrown on one side, and this is done alternately with the two points. The part $m$ is slightly curved, as well as the points proceeding from it. When it is intended to make a deep trench, as in cutting through turf in the marshes, 1 is laid parallel to $m$, while the rings at $f, f$, as well as at $i, i$, prevent the plough-share from going too far downward.

No kind of plough is used at Tornea, all the ground being turned over with the spade. The same is the case at Kimi, except in the fields where rye is sown, and aI 2 
these are ploughed with the plough just described.

It is a common custom at Kimi to furnish out a table with five or six plates, and as many spoons, napkins, \&c., though only one or two persons are expected to dinner. There is at the post-house a free table (or ordinary).

In the land belonging to the clergyman of Kimi, I found the (Lythrum) Salicaria with a very unusual aspect, having alternate leaves, and a solitary flower in the bosom of each. (The original specimens in the Linnæan herbarium have two or more Alowers to the upper leaves.)

My intention was to have extended $\mathrm{my}$ journey into the province of East Bothnia; but on applying at the post-house, I could neithèr procure a horse, nor any thing to vat, for the inhabitants either could not, or would not, understand me. I therefore took leave of them the same day I arrived, and turned my steps backward. 
The Finlanders in East Bothland are dressed very much like the Laplanders, and therefore agree with them in general appearance. Their dress is the same with respect to their cap, their light-grey jacket, their breeches reaching down to the feet, their half-boots, their belt into which they stick their knife, and the use of hooks and eyes upon their clothes instead of buttons. But they differ in not having a high collar, and in wearing a shirt and neckcloth, as well as in having their coat open before. They stick nothing into their girdle but a knife, though some people carry a key at the end of it. Their breeches are tied round the knees.

At church I observed some men with a girdle of black list, just as it was rent from the cloth, wound two or three times round the waist, which formed a contrast with their grey jackets. The women however dress in articles purchased from other countries, and make quite a different appearance from the Lapland females. 
East Bothnia, being a low country's abounds in marshes, bogs, and fens. The grass is tall; but still there is such a deficiency of hay, that they buy up horse-dung; at Tornea, and boil it, as I have said, in the boilers built up in some of their houses; in which also they boil water to pour over the reindeer moss.

The bread used by the inhabitants of this country in the present season of scarcity was made principally of chaff cut fine and ground.

The winter rye, sown but this day se'nnight, had already sprung up, and made the fields quite green.

I returned back to Tornea in the evening.

\section{August 13.}

This being a fast day, I heard a sermon in the Finnish tongue, preached at the church of Tornea. A lawful wife was churched, after her lying-in; which ceremony was performed in the choir, near the elevated part. The women in general had either naturally white hair, or hair that 
had once been brown, now turned grey. Very few had it red. They wear their hair rather straight.

The physiognomy of both men and women is phlegmatic and stupid; the body clumsy, the complexion bad, and the features destitute of all delicacy of form or expression.

The boundary between West Bothnia and East Bothnia is not formed by the river of Kimi, but by another smaller stream, not far distant, on the left.

They catch Sijk (Salmo Lavaretus) in a curious manner at this place. These fish, like the common salmon, swim against the stream, and for that reason are to be caught only near large falls of the river, which they are unable to ascend. The fisherman, being furnished with a net fixed at the end of a long pole, strips himself naked up to the waist, and walks into the middle of the strongest cascade. To prevent accidents from the force of the water, a rope is often ticd round his waist, the other end of 
which is held fast by a friend on shore. Thus they catch the fish below the fall.

Seals are taken by various means, being either shot with fire-arms, or caught in a net. The latter, three or four fathoms high, is made of hempen cord, as thick as a goose-quill, each mesh being two spans wide. This net is kept upright in the water by means of oblong floats of wood, and has no stones at the bottom. Four or five such nets are frequently tied to the ends of each other, and a large stone is attached to the last, bound about with willow or osier, which serves to keep the nets steady. These are set in places where the seals are known to hide themselves, for those animals do the fishermen great damage, not only by devouring fish, but by tearing the fishing nets, from the destruction of which the haunts of the seals are discovered. When a seal comes in the way of the abovedescribed nets, he either thrusts his head between the meshes, getting more and more entangled the more he pushes for- 
ward, or, as often happens, he is caught by the foot.

On a sand-hill near the church at Tornea, grew, in great abundance, Gramen spicâ triticeâ maritimum, (Triticum radice repente, foliis rigidis: $1 \%$ Lupp. n. 34, which, in the second edition of that work, p. 23, I have, by the persuasion of my intelligent friend Dr. Afzelius, referred to Elymus arenarius, and what Linnæus here says, confirms this determination.) Its blue leares looked quite different from all others, and rery handsome. I picked some seeds from the spikes, which were as large as grains of rye. Hence I was induced to consider whether this plant might not serve as a kind of corn, to be cultivated on such dry and blowing sands, provided the proper method of managing it could be discovered, which surely would not be a very difficult task. The adrantage of this would be that, by such means, many sandy tracts, where nothing else will grow, might be turned to advantage; and the perennial 
roots, which no other corn has, would of course save the trouble of sowing it annually. Perhaps even these roots themselves might, in hard times, serve for food.

The tall Finlander Daniel Cajanus, at Stockholm, born in this part of East Bothland, was the son of a clergyman. At his birth he was no bigger than the generality of children, and his health was very indifferent, particularly with regard to his chest, till the age of twelve or fifteen years.

I was informed that the inhabitants of this neighbourhood often hear thunder in the alps during winter.

In the alps of Tornea cold is brought by a south wind, and mild weather comes from the north, because of the sea.

The Laplanders consult several natural objects by way of compass as they travel.

1. Large Pine-trees, which bear more copious branches on their southern side than towards the north.

2. Ant-hills, the south sides of which bear grass, the northern whortle-berries. 
3. Aspen trees, whose bark is rough on the north side, smooth on the opposite part.

4. Old withered Pines are clothed, on the north side, with the black Usnea, or filamentous Lichen (L.jubatus).

By such marks as these they are able to find their way through pathless forests. Have we any guides so certain?

When these people kill any wild reindeer with fire-arms in summer, they lodge the carcase in a cold cellar, and cut it up as they want it for provision.

I observed a curious kind of lime-stone burnt at Kimi, Tornea, and other places round the neighbouring sea-coast.

\section{August 14.}

A very rainy day. A silver ore from $\mathrm{Hjor}$ tot has been assayed by the Mineral Board, and found to contain forty per cent. lead, but only three or four of silver. 


\section{August 15.}

Near the ferry at Tornea I picked up the Fresh-water Sponge, Spongia lacustris of Newton, (S. lacustris; Syst. Nat.v.1. 1299. Linnæus here refers to Mr. Newton, the friend of Ray, who found the Sponge in question in the Norwich river, where it still exists. It is howerer denominated in Ray's Synopsis, S. ramosa fluviatilis, not lacustris. Linnxeus quoted from memory.)

\section{August 16.}

In dissecting the flower of Artemisia (vulgaris), I was struck with its very curious conformation. (This alludes to the want of a limb to the corolla of the female or marginal florets. See Fl. Lapp.ed. 2. 244.)

$$
\text { August } 17 .
$$

I went by sea from Tornea to Calix. The wind proved contrary. The islands abounded with Whortle-berries, and with the fruit of 
Irubus saxatilis. On one called Korsholm I met with a sort of Behen. Can it be the same with that which grows in cornfields? Their different parts are tolerably alike. This grew among the pebbles of the beach. Its calyx is oblong. Leaves narrow. Stem erect. Fruit of one cell. In other respects it resembles Behen. (This was Cucubalus (Behen) variety the third, or $\gamma, F l$ Lapp. n. 180. ed. 2. 149. Silene maritima, Fl. Brit. 468. Engl. Bot. t.957. We have found it remain for many years unchanged in a garden, propagating itself by seed, though Linnæus reports that the third year he could not distinguish his from our common Silene inflata, his Cucubalus Behen.)

\section{CECONOMICAL REMARKS}

\section{CONCERNING}

THE NEIGHBOURHOOD OF TORNEA.

The soil is various, sometimes clay, sometimes sand. The corn-fields are sown every other year, and lie fallow the intermediate seasons, half of each field lying 
fallow, while the other half is cultivated. The former is ploughed during the whole summer, to prevent the growth of grass or weeds, "hich might exhaust it. Barley is sown in these open fields only. Rye is cultivated on land that has recently been cleared of its wood by burning, but not in any great quantities. Turnips and Rye are sown together in one crop, and not, as usual in other places, Turnips one year and Rye the other. Rye bread is reserved to treat visitors. Barley bread is of three different qualities; 1 . made of the unmixed barley; 2. of a mixture of barley and chaff; 3 . of chaff without any addition, except now and then a handfull or two of barley. This last is their Spis-bröd, or household-bread.

The plough is of the same construction as that used in Westbothland.

Almost every person, except such as are very poor, catches as many of the small lind of Herrings, called Stramming (Clupea Harengus $\beta$, Membras of old authors,) as 
are necessary for the support of his family. Those who are not otherwise employed in spring and autumn, catch them for sale afterwards to such as have not time to take any for themselves. These fish begin to spawn about the 18th of May, and continue till about the 16 th of June. After the latter period they go into the small inlets among the rocks, and are taken by means of large nets till St. Peter's day, June 29th. This is called the large Strœmming fishery. From St. Peter's day till St. Bartholomew's (Aug. 24th), or even later, they are taken likewise with nets in their usual haunts. These fish are found with milt as well as roe throughout the summer.

One barrel of sour Stromming is as valuable as two of the salted sort, the former being greatly preferred. A peasant whose family consists of a dozen people, takes half a barrel of salt Strœmming for his whole supply, and this is used to make a kind of soup when boiled with turnips; but he takes a barrel and three quarters of sour 
Stromming, which is eaten without any preparation, like smoked and salted meat. If the director of the family is a good reconomist, he will never allow it to be boiled or roasted. They let the fish which is to make sour Strœmming lie for three or four hours only before they take out the entrails, after which it is washed in a small coarse sieve, till most of the blood is removed. It is then salted, in the proportion of thirty pounds of ordinary salt to each barrel of fish. The fish destined to make salt Strœmming must be much more carefully washed, for if the least drop of blood remains it will turn sour. Every barrel of this requires a quarter of a barrel of salt which is disposed in layers, alternately with layers of fish. Each layer of fish and salt are rubbed together with the hands, till a sort of scum rises on the top.

Another way of preparing salt Strœmming is to make so strong a brine that the entire fish, thrown into the tub, will not sink. They put in only so many of the 
fish as can readily be stirred about in the brine. If the tub be so full that the brine does not entirely cover the Strœmming, more is added, and the whole is suffered to remain for some days. The fish is afterwards gutted in the following manner. A person puts ten or twelve of them on the thumb of his left hand, in such a manner that the back of each fish is turned towards the palm. He then very dexterously loosens the gills with his right hand, pinching out the gills and intestines at once; which is performed with great quickness. The fish are then put into a rope basket, and salted as before. When they have remained thus for a couple of days, they are put into other baskets, in order that the brine may drain away, and finally are packed up in new kegs for keeping, without any further salting. A hole is bored in each tub, just above the lowermost hoop, to draw off the brine, which is always collecting from the fish, and if permitted to remain, will cause the whole to VOL. II. 
turn sour; but the same method is not practised for the sour Strœmming. This last is in its greatest perfection about $\mathrm{St}$. James's day (July 25th).

These people have three meals a day in summer, besides breakfast, and the sour Stromming always makes a part of their dinner, as well as of the preceding refreshment. The fish, after being repeatedly squeezed, is laid between two slices of bread, and so eaten. After it they take some sour preparation of milk, without cream. Sometimes indeed they eat a bit of cheese, or bread and butter; but they never eat meat after the sour Strœmming. Their vegetable food consists of cabbage, pease, or turnips, the first being generally eaten on Sundays. Pease are eaten once a week, except when the cabbage is deficient, and then they supply its place. Turnips and salt Stromming are generally eaten in a morning, in the following manner. When the turnips are boiled nearly enough, the fish is put to them, but not 
before, lest it should be broken to pieces. To this some flour is added; and they drink sour milk after it. Their supper always consists of flummery, made of barley-meal. Before they first go out in a morning they eat either bread and butter, or bread and cheese, but they prefer the former. The mixed bread (made of corn and chaff) is their ordinary portion; good bread, made entirely of corn, they seldom or ever taste. It is reserved for visitors, or for very extraordinary occasions. Their mixed or household bread, being baked in cakes as thin as paper, is eaten by laying four or five such cakes together upon each other. They are never unprovided with ale in their cellars, to treat visitors, though their ordinary drink is table beer. In summer time they always drink Syra, (see vol. i. p. 243.)

The peasants themselves eat but very little of their own mutton, and chiefly the shoulder and brisket. The rest they sell; scarcely any is kept in the house but the i 2 
above parts, with the marrow-bones, which they break to get at the marrow. The heads and feet of sheep, goats, and hogs, are salted and dried, being, when wanted, boiled with pease, and not ill-tasted. The legs of sheep, cut off at the knee, are often boiled fresh; the fat which floats on the top being collected and preserved in a horn or pot, as very useful to grease small ropes, and wheels. The legs and feet thus boiled are afterwards thrown away, not eaten. The head and feet of a calf are usually pickled.

For fire-wood these people use birchwood. They burn no candles in their houses. They go to smoke themselves with the Finlanders in their huts.

The hay is mown here in the same manner as in Upland, and the corn is managed in the same way as in Smoland. When the season is dry, they prefer drying the corn in heaps in the open air, as before described; but in wet weather they have rerourse to slieds. The hay is spread out 
till dry, and afterwards carried, without being made into cocks.

They raise as many hops as arc wanted for each family, and have perhaps a few pounds over, for sale.

Their pales are high, made of pine-rood, and placed sloping.

The milk is set in the cellar, in deep tubs made of alder wood, by which they obtain a great proportion of cream, even two fingers' thick. This cream is stirred up with the mill;, warmed, and then coagulated, for making cheese. Another mode is with butter-milk, to which they add a sixth part of fresh milk, that has stood one day and been skinmed. This mixture, being first warmed, is then coagulated. The cheese thus made is preferred to the former, and often eaten in preference to butter.

Between Midsummer and St. James's day (July 25th), the whey is collected, after the cheese is made; which, after boiling for some hours, is set by to cool. When cold, it is barrelled up for winter use. Poor 
people and old women beg or buy it, a small bottle-full at a time. To one pot of sour milk they add a fourth part of Syra; and these togrether have the taste of what they term Filbunke, which is sour milk with the cream on, just beginning to ferment, and of which they make Servetmjolk; (see p. 150.)

Thick milk (perhaps Mesosmör, see vol.i. p. 243,) is often kept in barrels till winter, as is the meal made of fir-bark, when both serve for winter provision.

Syra is so very sour as not to be eatable by itself. When they have no milk to dilute it with, they add an equal quantity of water to the $S y r^{\prime} a$, and mix the whole with flummery, which mixture they prefer to small beer.

Butter is now and then made of goat's milk; but it is very strong, and quite as white as that made of the milk of the rein-deer. 


\section{August 18.}

On islands near the shore I saw a Salix with leaves like the cultivated olive. It is a shrub three feet high, but growing in a spreading manner. Stem grey, with roundish dusky solitary buds, of a very large size, in proportion to the plant. Leaves gradually larger(upwards?), oblong-lanceolate, bluntish, on scarcely perceptible footstalls, furnished with an obtuse longitudinal rib beneath, but no veins. Their upper surface is green, sprinkled all over with minute white dots; rery sliglitly channelled, and paler, along the nerve. (This appears to have been S. rosmarinifolia.)

\section{Augुust 19.}

At the fair of Calix I obtained some information concerning the commerce of this country, which is very different from that of almost every place in the world besides, insomuch that I am unable to determine which party makes his market of the other. 
The townsnan thinks it is himself who cheats the peasant, but I verily believe he is the party who is cheated.

1. The general plan of traffic here is bartering one article for another.

2. The merchant generally carries his goods home to the peasant's residence in the country, at whatever distance it may be, or else conveys them to the fair, from whence the purchaser is to fetch them.

3. When a townsman sets up trade as a merchant, his principal aim is to get as many country-people to connect themselves with him as possible, who are to supply him with their produce. These are termed Gield-bonder, or creditor's.

4. The advantage the peasants have in thus confiding to the merchant the whole of their goods, is, that the latter pays their taxes for them to the collector, which must be clone either in ready money, or bills of exchange.

5. When the merchant receives the goods from the countryman, no price is fixed upon 
them between the parties; but when the former returns from Stockholm, he sets down in his accompt-book nearly the sum for which he has disposed of the articles there. In this the peasant trusts to the honour of the merchant; and is paid accordingly.

6. These prices are not communicated to the countryman immediately, nor does he know the price of the salt, tobacco, corn, and other articles, with which the merchant supplies him in return, till they settle accompts; which does not take place till the end of every year, or perhaps not so frequently.

7. As long as a peasant keeps to one merchant, he is allowed credit, and obtains advances of any money for which he may have occasion, even although the goods delivered do not amount to the interest of the sum lent, which is sometimes equal to 1000 dollars. But if he carries any of his goods to another merchant, he must immediately pay what he owes to his original correspon- 
dent, or suffer a sequestration of his property.

8. The countryman never brings his own goods to market, unless he happens to be going that way, in which case he usually takes them with him, but otherwise it is expected the merchant should fetch them.

9. When the towns of this part of the country were first built, each had certain parishes appropriated to it, and these were called the trading district of each town, in which no person who did not belong to the town had a right to trade. These exclusive privileges were subsequently annulled by royal authority, and fiee markets were established, where strangers as well as the neighbouring inhabitants were equally permitted to trade. This open trade has not however taken place at Calix, partly because the peasants are situated at so great a distance from one another, and partly because the merchants in the town conceive that such a plan would ruin them, 
they being in that case obliged to buy and sell for ready money.

10. Here are no free markets, properly speaking, but only Upbördsmoten (periodical meetings of the collectors of the revenues with the peasants). At these times the townsmen and the peasants meet together at the place of rendezvous, as at Calix every year on the 19th of August, and at Tornea in the depth of winter.

The inconveniences of the above plan of trade are,

1. The merchant lays considerable sums fast, with which he might otherwise extend his commerce.

2. He has the trouble of carrying his goods to the house of the peasant, whereever it may be, up the country, and of bringing what he takes in exchange from the place of rendezvous to his own house in town.

3. The consequence of such a plan is, that many a merchant has outstanding debts to the amount of 100,000 dollars, 
the greater part of which he may nerer get paid.

The inconreniences to the countryman are,

1. He runs in debt more than he can ever pay.

2. The merchant has the advantage of fixing what price he chooses on his goods.

3. He is not allowed to take any measures for his own profit.

The collar of the shirts, worn by the inhabitants of Finland and East Bothland in this neighbourhood, resembles ours, their sleeves being more like those of a woman's shift.

Young women here commonly wear the bosom open, and have nothing over their shift, which is gathered round the waist like a petticoat.

The country of East Bothland is chiefly inhabited about the sea-coast, and on the banks of rivers.

An Aurora borealis was seen in the night 
of the 18th of August, and had been visible for a week past, so early does it begin here.

The rowers of the boat in which I pursued my progress had blisters on their hands caused by pulling at the oars. Their specific was the ladle with which they had just been stirring the pot where fish was boiling. This they applied, hot as it was, to the part affected, and the blisters disappeared.

What is here called Taim is a sort of salmon, two spans in length at most, the tail scarcely cloven, the mouth not hooked, but otherwise like the common kind. (This is probably the Salmo salar in a young state; and may perhaps be the Laxunge, or Salmo minor, vulgari similis, Artedi Spec. 50, not 80, mentioned in Fauna Suecica, ed. 2. 122, though Linnæus has no allusion there to the Taim.)

As soon as the corn is carried from the field, it is usual to thrash it slightly, that whatever is loose may come away, and not be lost in the barn, as also that the 
coarser part may be separated from the finer.

The flail is about a yard long, and rather thick.

The roofs in this part of the country are made of the bark of birch-trees, not covered over with any turf, but held fast by round poles, as thick as one's arm, whose upper extremities, alternately longer and shorter, reach to the ridge, and being bored through, are fastened to it, in such a manner that their ends project about a span each way beyond the ridge, crossing each other. Being thicker at their lower ends, they lie almost close together. Within this there is often a false roof, like a cieling, covered over with birch-bark and earth; but this is only when the house is wished to be very warm.

At the residence of the Governor of the Province at Calix, I saw three swans, which, having been taken when young; were as tame as domestic geese, to which these birds are so much alike in every respect, 
that I can have no doubt of their belonging to one genus. Their bill is flat, and black at the extremity, as well as the margins, convex and somewhat angular in the middle, so far at least that the swelling part terminates in an angle. The middle is fleshy, where the oblong nostrils are situated; the base flat or quadrangular, with two sinuses pointing upwards, and pale-coloured. The margin is toothed just like the Concha Veneris (Cypraca).

A carriage called Stotting is used here, for bringing home wood for fuel in winter, over the ice and snow. It is made of birchwood, and resembles a sledge.

The length of this machine from a to $b$ is three feet and a half, the breadth of each beam four inches and a half; their thickness two inches, except in the middle, at $d$, where it is three inches and a half, though in all the other parts of equal dimensions. The transverse bar, $c$, is one foot and a half long, three inches and a half broad, and is elevated four inches above the longitudinal 
pieces. e, e, are two slender triangular pieces, two feet in length, and two inches in thickness. $f, f$, are about one palm and a half each in length and breadth. $h$ is curved upwards about two palms and a half out of the straight line. $\mathrm{g}$ is two feet long between the main beams, three inches and a half broad, but scarcely one in thickness.

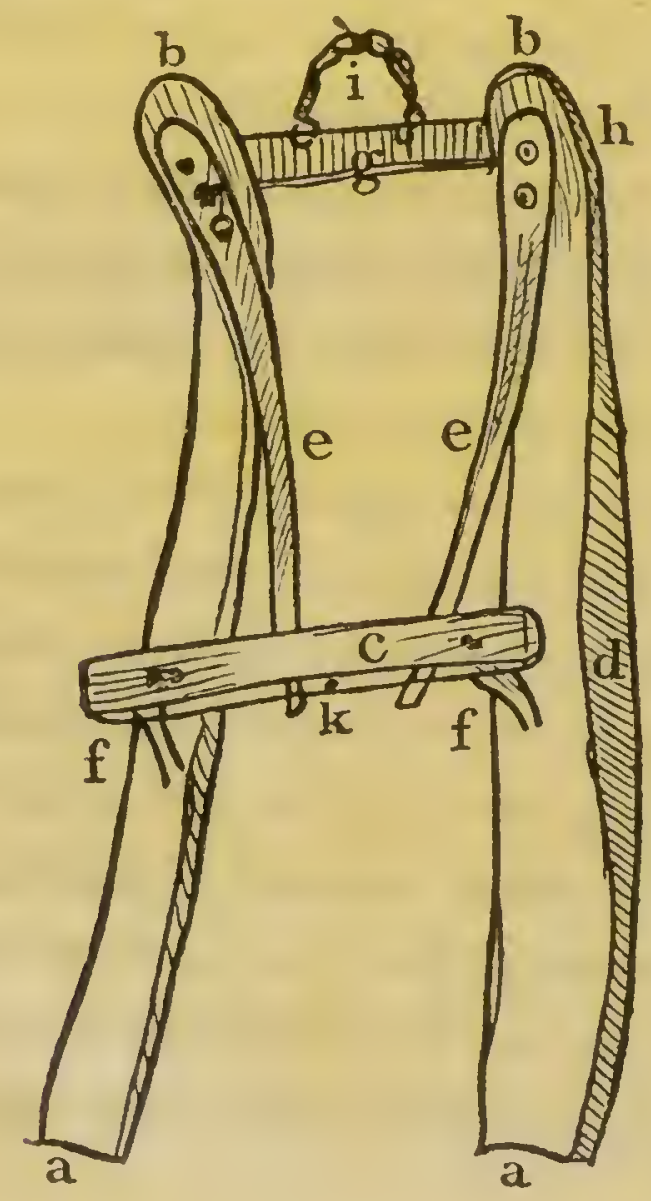


The sledges, or beams, $a, b$, differ from the common ones in being broader, and in the elevation or thickness of each at $d$. The transrerse beam c, on which the load is laid, is bored through at each end, to receive the supporting pieces. The slender bars e, e, which may be termed clavicles, are broadest in the fore part, where they also are bored through, and fastened with pegs, serving to give stability to the cross beam c. 'Two of these carriages are tied together, one behind the other, through the hole in the cross beam, at k. The loop, $i$, is made of birchen twigs.

At Calix I found the Hippuris (vulgaris) with forked branches; Pentaphylloides facie fragarice, (Potentilla rupestris?); and Eruca foliis sinapeos. (What this was does not appear.)

I noticed lime-stone in the cliff at Calix and Tornea. 


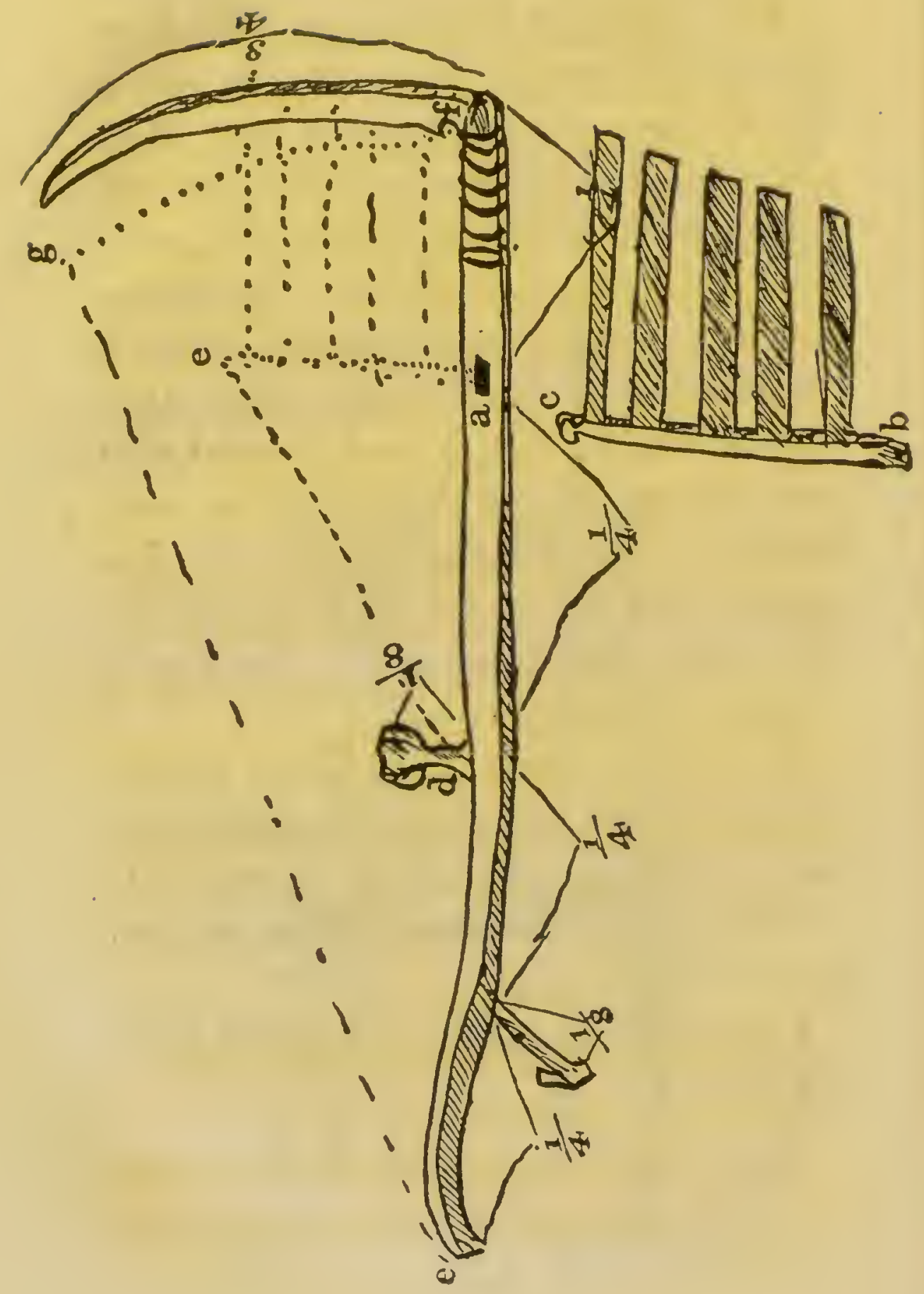


The scythe which serves at Cronby in East Bothland, for mowing barley, is made exactly like the common one of the Finlanders, with the foremost handle underneath, but, that nothing may be wasted or lost, the machine b c is fixed to the scythe, $\mathrm{b}$ being stuck into the hole at a, and fastened with a pin through it at the other side. A cord is tied from the other end $\mathrm{c}$ to the handle $d$, before the scythe is used. The lower, or shortest, bar of this appendage scarcely extends beyond the extremity of the scythe at $f$. Its position is regulated by a cord, according to the inclination of the blade $f \mathrm{~g}$.

The length of the main handle of the scythe, ef, is two ells.

\section{August 31.}

I collected and described various species of Fungi.

(Here follow descriptions or characters of several species of Agaricus, Boletus and 02 
Hydnum, given more correctly in the Flora Lapponica.)

\section{September 3.}

I stood sponsor to the son of the Burgomaster Geyer Svanberg, who was born the preceding night, or rather between one and two in the morning. He was named Geyer.

Mr. Svanberg told me the (Cotyledon) Umbilicus Veneris grew on a hill called Karvick, near Wallivari to the north. (This probably was not confirmed, as the plant does not occur in Flo. Suecica.)

\section{September 4.}

I went to Biorknas, in order to be instructed in the art of assaying.

\section{September 9.}

I examined the fish called in West Bothland Natting, (Petromyzon fluviatilis.) Its upper jaw is acutely notched, resembling two teeth. The lower has seven small 
teeth; of which the two outermost are largest. Mouth in the under side of the head, gaping, oval, rather compressed. There are seven openings in a row behind the eyes, gradually larger as they recede from thence. The fins have no visible rays, but merely streaks, yet they are not adipose, or fat, fins. There is a prominent orifice on the top of the head. The pericardium is cartilaginous. The fish is a span long. Its lind fin triangular.

These (lampreys) are caught at this time of the year, when the nights grow dark, in hollow timbers of a conical shape, resembling the wicker baskets used for catching eels. The entrance is made smooth and even. These timbers are laid, at the depth of two ells, in the river, and kept down with stones, the opening being turned to meet the current.

Some such traps are made of willowtwigs not bigger than goose-quills, platted close together into the same shape, and are two ells in length. 
I was told that the Laplanders are accustomed to preserve blood of the reindeer in rennet-bags through the winter till spring, when they boil it with water, and drink it.

Tar is obtained in the following manner: A cavity, of an inversely conical shape, is dug in a hill, and then lined with hewn timbers, nine ells in length each, so as to form a sort of funnel. This again is lined with bark of pine-trees, so as to prevent the tar draining away into the ground between the timbers. At the bottom is another funnel or vessel of woot to reccive the tar, which runs from thence into a trough, close on all sides, except a hole.where the point of the said funnel is inserted, and another at the extremity, closed with a moreable plug, from which the tar is received into vessels and taken away. Roots of fir, cut to pieces, are placed upright in the large funnel above, so as to leave a convexity over the bottom, and the whole being corered with turf is set on fire, against the 
wind. Care is taken, by varying the admission of air, to prevent its burning too fast, or unequally ; and by this means they procure both tar and charcoal.

\section{September 14.}

I took my leave of Biorknas. The weather was cold and rainy. Such of the forest trees as are of a deciduous nature had now assumed a pallid hue, in consequence of the cold nights; but the evergreens, with their needle-shaped leaves, standing among them, seemed to defy the cold, and were rendered conspicuous by their dark-green colour. The high wind scattered the withered leaves over my path. How useful are the usual storms of autumn to disperse ripe seeds, and plant colonies far from the parent trees! The hills appeared sandy; and such places as had been burnt were now perfectly white with Reindeer Moss, (Lichen rangiferinus, which grew so close together, as hardly to leave any room for the Ling. It ornamented the sides of the roads 
like the Iceland Moss, (Lichen islandicus.)

Some part of the road consisted of a reddish-brown earth, such as $\mathrm{I}$ had observed in the early part of my journey near Umœa. I was told that it was excellent for red paint. At length I reached Zingis, and in the evening arrived at Tornea, entirely wet through.

\section{September 15.}

I observed how they manage their corn at this season. They have no barns to lay it into, but it is placed between poles, all the cars clirected to one sirle, in stacks two or three ells long, and very high. If the corn be not quite dry, it is first spread abroad. Afterwards it is dried in a kiln, and thrashed on a floor. How liable must it be to take fire, and how much must unaroidably be spilt in consequence of such management!

I received 100 dollars, of copper-money, from the chicf clergyman. 
I learned here that Tansy (Tanacetum vulgare) and Mugwort (Artemisia vulgaris) are used to make a fomentation or bath, wonderfully useful for women in labaur, who are accustomed to sit over the steam of these herbs. I had observed the people at every house drying Tansy, but could meet with nobody who would inform me to what use it was destined.

\section{September 16.}

This day I again left Tornea for Kimi. There are six ferries between these two places, orer the river Kolsama, which passes near Kimi. Two miles from hence are the boundaries of East and West Bothnia. Lime-stone attracted my notice all the way along the road to Norbotn; it was yellow on the outside, whitish within.

\section{September 17.}

I departed from the postlouse of Kimi. The weather was unfavourable, for it rained all day long. I took up my lodging in the 
evening at the posthouse of $\mathrm{J}_{0}$. This part of the country lies very low, abounding with marshes and numerous small rivulets, but few lills. There is plenty of grass. The buildings are bad. The forests consist chiefly of Birch, intermixed with the acifolice(slender-leaved evergreens). Of these last the Juniper was remarkable for its abundince and large size, so as to be almost arborescent. The Birch and the dwarf Willows had now become pale, but the Sorbus (Mountain ash, Pyrus aucuparia, Fl. Brit.) had assumed a red hue, as well as all the mosses. (Pedicularis) Sceptrum Carolinum appcared every where by the roadside. Thalictrum (flavum) and Scutellaria (galericulata) were less frequent, but Golden-rod (Solidago Virga aurea), Trollius (europceus), (Spiraa) Ulmaria, and Epilobium (palustre?) were plentiful, as was the sweet Milium (effusum), with the Gramen ramosum (probably Aira cespitosa.)

The inhabitants were in their smoky huts, with their eycs full of smoke, and the 
tears running from them. Nevertheless they seemed more studious of warnth than careful of their eyesight.

The same sort of plough is used here as at Kimi.

I had frequent riews of the sea through the woods on the right hand. Wherever the wares had thrown up sand-hills grew a pea with a triangular stem, a white creeping perennial root, and thick leaves alternately pinnate, (Pisum maritimum).

Near Jö I noticed a pit-fall designed to catch wolves. This was dug in a hill, at no great distance from the house. Around it within were eleven pales or stakes, placed upright and close together. In the centre stood a polc, which, as well as the pales, was on a level with the surface of the ground. The pole supported a wheel, over which were laid boards, so as entirely to cover it, in such a manner that if the wolf, when caught, should be able to climb up as high as the wheel, he might not get any further. 
The peasants of this upper part of East Bothnia, children of darkness in their houses, are no less so in their slovenly appearance, chiefly owing to their uncombed hair. Their breeches reach as low as the feet, and are white, and they wear a sort of short cloak, sewed together in front.-Their disposition is quarrelsome. Their habitations are infected with a smell of sour fish, like sour Strœmming, for they are liept very dirty. These people speak no other language than the Finlandish.

Here and there by the road I had this day travelled, I noticed the Sea Wheatgrass, (Elymus arenarius. See Fl. Lapp. ed. 2. 21. 31.)

\section{September 18.}

I travelled from $\mathrm{J} \ddot{\mathrm{o}}$ to Ulaborg. The rye was bound into sheaves, ten of which were piled up together in a heap, the ears at the top of each being brought close together, and another sheath being placed, in an inverted position, upon them, the 
whole was sheltered from wet. The barley was not set upright, but laid on one side, in such a manner that the ears were all turned inward, and the straw stood outward all round. On the top of each little stack thus formed, a reversed sheath was put, as a lind of covering.
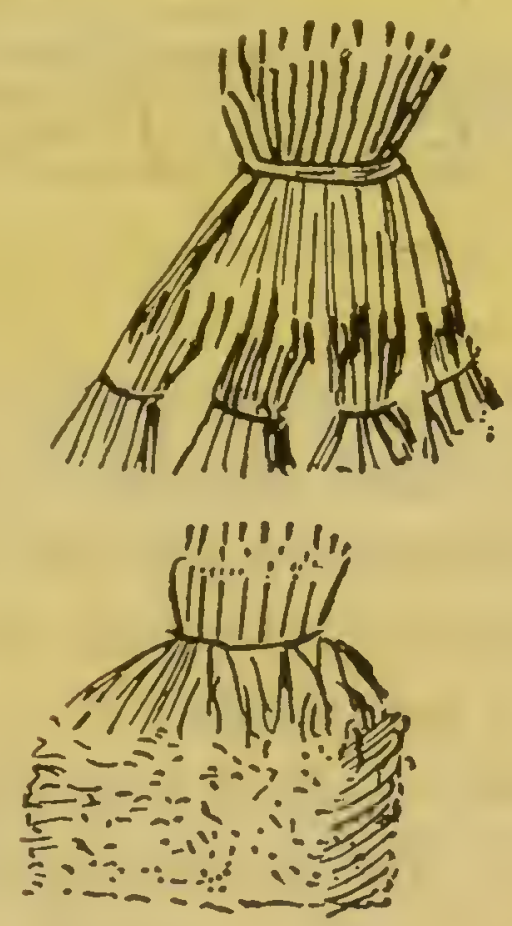

The villages consisted of the same kind of smoky huts I have already described. 
(The annexed cut seems to be a representation of one of these dwellings, at which Linnæus was so indignant.)

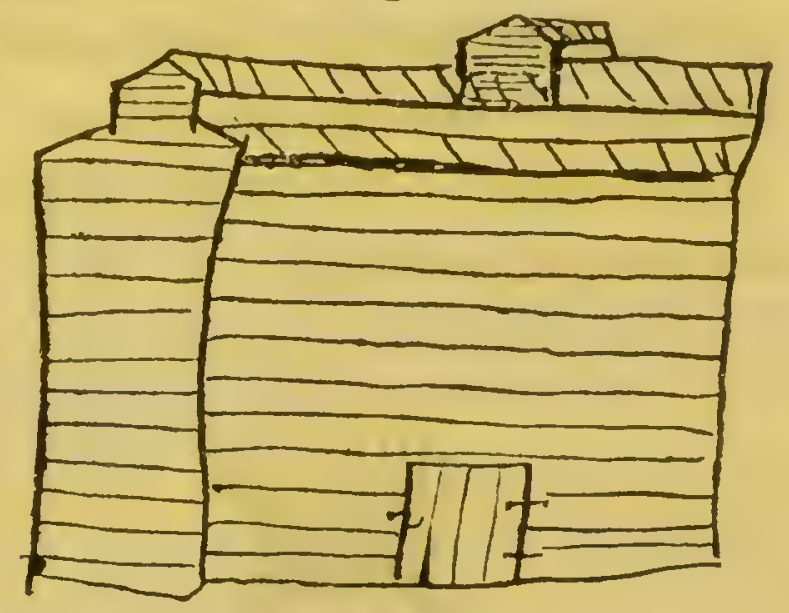

Near the ferry of Haukipudas, stones are collected from the shore, which, though nothing but concretions of sand and small pebbles, are so firm as to serve for the construction of ovens. At one spot, where the river had excavated the sandy bank, it was evident that the cement, which combines these particles together; is no other than a rust of iron. The stones in general hereabouts are very fine-grained, and break easily. They have all the appearance of containing a portion of iron. Some were more rugged and rusty than the rest. 
A kind of boats used here to navigate rapid and dangerous parts of the rivers, are made of thin planks of spruce fir, and are four or five fathoms long, and about one broad in their middle. The sides are five or sis quarters of an ell deep; the extremities compressed. The middle of the boat is nearly semicylindrical, the keel being raised up, or hollowed as it were by the dilatation of the sides, in which all the importance and peculiarity of the contrivance consists, for without this the vessel would be much more easily overset in rapid and shelvy places. Some of these boats have no prominent keel at all; others are furnished with a slight one, chiefly in their forepart, which is a little the highest, in order to bear the better any shocks from striking against stones; so that if this part be able to pass, the rest of the vessel may go in safety.

One sort of nets used for catching Sijkfish, (Salmo Lavaretus, or Gwiniad, before mentioned) are five spans high, and of a 
considerable length, the meshes very small. There are loop-holes at the top, large enough to admit two fingers, bordered with birch bark, whose edges are sewn together. (See 1, 2, 3, 4 in the figure.) The stones $(5,6,7)$ at the bottom are but small, covered with birch bark. The nets are set near the sandy shore.

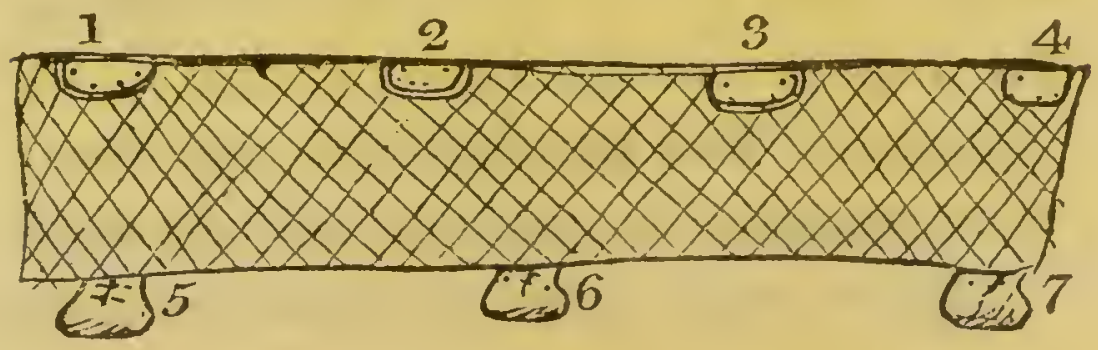

Another kind of net, used for catching the same fish, is placed in the strongest part of a current or water-fall. It resembles a receiving net, except being not so decp. The length is three ells, breadth two, and depth one. This is fixed very steadily, by means of poles, in the middle of the very strongest and most confined current, against the stream, so that when the fish attempts to pass upwards, by the narrow passages on 
each side the net, he finds it impracticable, and is thrown back by the force of the water, generally into the net, out of which he can never escape, but is taken out at leisure.

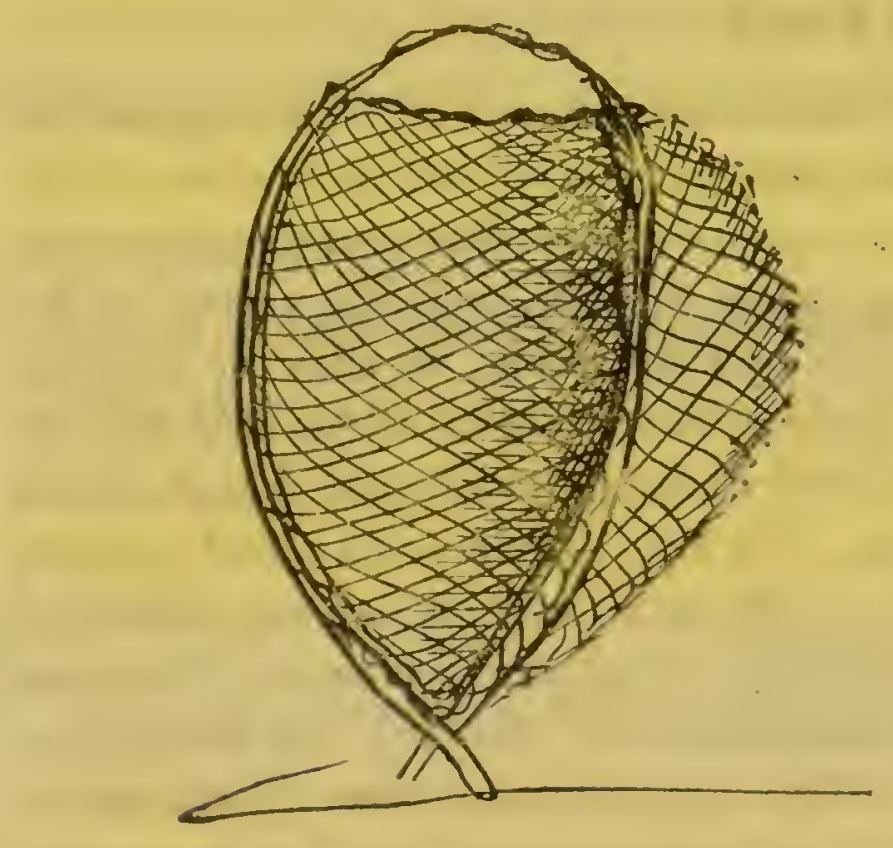

Near Ulaborg is a mineral spring, not yet made any use of. The taste of the water seemed good. This spring is situated close to the town, on a small island, where there is a sawing-mill.

In the church I noticed the monument of Messenius, with his effigy made to the VOI. II. 
life. He is actually buried here*. This church is one of the longest I ever saw built of wood, but its height is not correspondent. The arms of the town are displayed on the pulpit. Ulaborg is almost as. large as Lund.

* John Messenius, famous for his learning and his misfortunes, was professor of law and politics at UPsal, in the reign of the great Gustavus Adolphus, who had a high esteem for him, and who exerted all his wisdom, and even his power, to allay the envy and hatred of some of the colleagues of this able man, especially of John Rudbeck, a malignant though learned theologian. The king in vain endearoured to pacify Rudbeck by preferment, while he removed Messenius to Stockholm, and made him a member of the new council established there. The latter was formally accused of being a secret partisan of the deposed catholic king Sigismond, and was condemned to a perpetual prison, where he composed a great work entitled Scandia illustrata, published at Stockholm between the years 1700 and 1714. Messenius died in 1636. His son Arnold might be justified for detesting those who had persecuted his illustrious father, but not for the folly of expressing his feelings in satirical publications against people iu power. For this he paid with his life on the scaffold in 1648, and his own son, aged about 17 , suflered with him. 


\section{September 19.}

After attending divine service I left this place. Sledges in use here are constructed with a cross board to rest the feet against. ( $a$, seems to be a bandage or belt, to keep the traveller from being suddenly jolted out of this vehicle, and $b$ is the part to rest the back or head against; but there are no references in the manuscript to these letters of the sketch.)

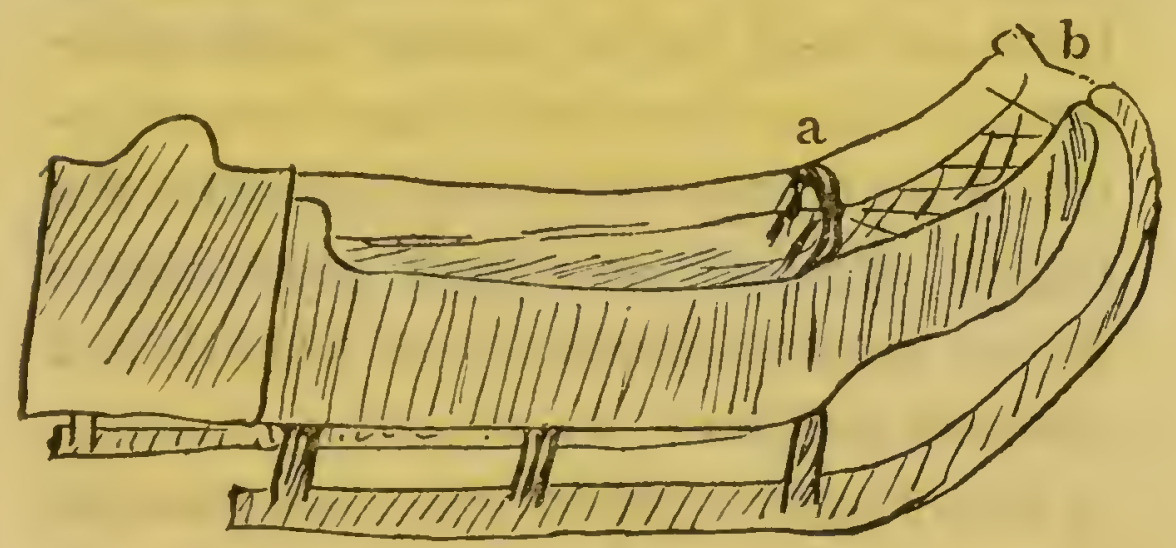

I now came in sight of the extensive meadows of Limingo, more spacious than all the meadow-ground of Tornea and Rödbeck logether. (Tuneld says in his Geography, that the meadows of Limingo, s 2 
and cornfields of the neighbouring parish of Storkyrro, are famous to a proverb for their great ex tent.) At first the land seemed a perfect marsh, filled with Horsetail (Equisetum fuviatile), and especially with Reed, Arundo (Phragmites), which last grew in such abundance as to resemble a forest. The Water Hemlock, Cicutaria aquatica Cicrta virosa; (see p. 136), was very plentiful by the road-side. This led me to inquire whether the cattle ever fed there? I was answered by the peasants in the affirmative, with a question in my turn, whether I could give them any advice on the subject, for they had lost a great many; adding similar particulars to what I had heard at Tornea.

Red Currants (Ribes rubrum) grew all the way by the road, as well as Lenticula (Lemna or Duck-weed), and the Lichenoides of which powder is made was observable on the trees. (Lichen prunastri, said to have been used for hair-powder.)

The maidlow of Limingo is two miles 
in length. The best part of the land, near the village of that name, was now occupied by the horned cattle. 'The land here is more elevated and less nuarshy, though somewhat impaired by tumps (of Carex cespitosa). If but a third part of it were cultivated, according to the Scanian mode of husbandry, it would be of more value than the whole is at present. I was told that the whole marsh might be laid dry, by cutting a channel down to the seashore; but it was feared that the land might in consequence become covered with White Moss (Sphagnum palustre), which would render it altogether unprofitable.

About a thousand hay-cocks were now before me on the meadow, but none of them consisting of more than a horse could draw. 'They never here use more than a single horse or ox at a time for draught. Each of these cocks was raised from the ground on a lind of scaffold, supported by several cross poles. Some of the Water 
Iris (Iris Pseud'acorus) was mixed with the hay.

The milli-strainers are made of straw, and not very clean.

\section{September 20.}

Brabestad, not far distant, is a small town, though twice the size of Tornea, standing on a peninsula by the sea.

In the hospital of $\mathrm{Cronby}$ are many maniacs, whose insanity is said to have arisen from jealousy of the conduct of their wives. One of them, whose wife was a very old woman, took this fancy, supposing her to intrigue with several other men. Possibly in these cases impotence, or perhaps some fantastic concupiscence, may have been a cause of the derangement.

About this neighbourhood it is the custom to administer to women in labour a very nauseous medicine, which is called Hittatran, or Casual Train-oil ; so termed because it is obtained from the carcases of 
such seals as, having been killed early in the spring, have been left among the broken ice till they are by chance cast upon the shore. They are consequently putrid, and the oil is so offensive, that few persons, except such as are in great extremity, or not very nice, can be brought to take it. In general Castor is here considered as a sheet-anchor in such cases, as being found by long experience very effectual in bringing on the labour-pains. Others take saffiron infused in wine. For after-pains they swallow, as at Kimi, a few drops of blood from the umbilical cord, not only in the woman's first lying-in, but every subsequent one.

Some Finlanders, as I was told, have a method by which they pretend to catch bears, with a sort of magic. 'This is done by procuring some of the bear's dung, fresh and warm if possible, and mixing it with that of one of their own cows. The consequence is said to be, that the bear will be attracted by sympathy to come after the 
cow; an effect certainly not more wonderful than many sympathies upon record.

There is a fish in the lakes near Pyhejorlis which is called Muicu. Bishop Terserus, a Dalecarlian, bishop of Abo, says that he has seen at this place a fish named Muicu, which is no other than the Blikta, taken in the lake of Silian in his native country. How true this may be I know not, but I saw plainly that this Muicu is the Small Sijk (Salmo Albula), such as is found in Smoland.

The following fig ure represents a plough used here, drawn by an ox. The share, a, is of iron, a span long. The part $b$ is four spans high ; $c$ is four spans long; $d$ and $e$, three spans each; $f, g$, four spans. The ends of the shafts are connected by a curved piece of wood, which keeps them from the shoulders of the animal, and supports them. 


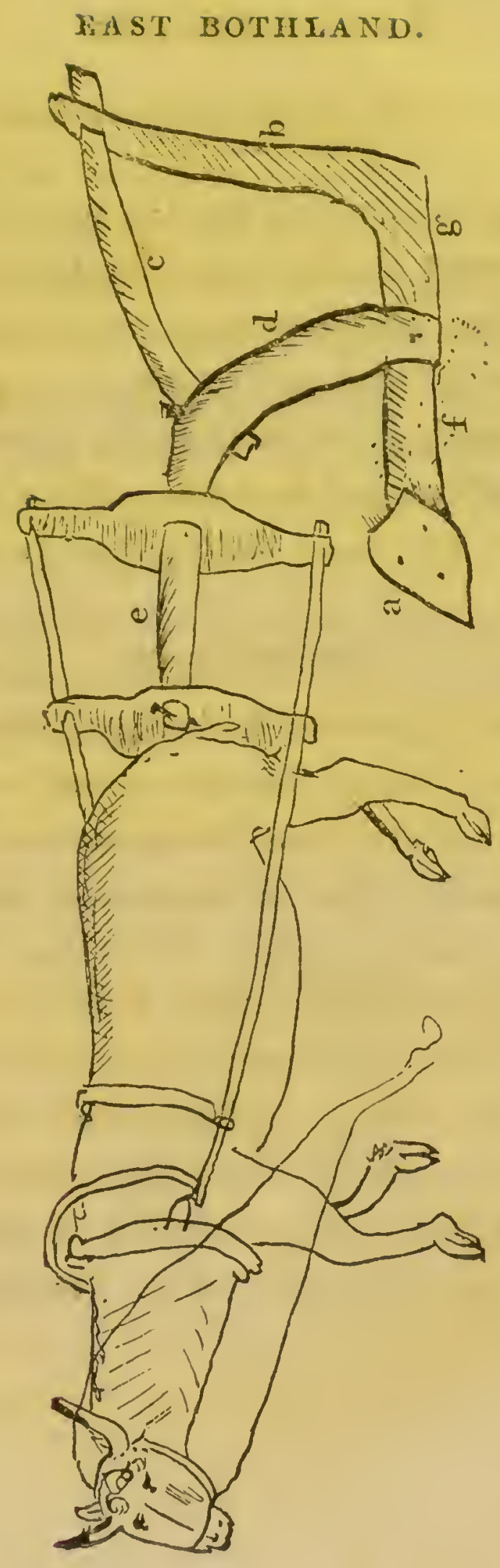

217 


\section{September 21.}

Being the feast of St. Matthew the apostle, I went to church at Gambla Carleby. Here is an introductory school, to prepare children for that at Cronby.

I passed on to Jacobstadt, which has a remarkably good harbour. Ships are able to load and unload close to the quay.

\section{September 22.}

Leaving Jacobstadt, I arrived at the town of New Carleby, which is nearly as big as Wexio. Every one of the streets is laid with timbers, placed cross-wise, instead of stones, like a bridge, which has a handsome appearance. The harbour of this place is near the river, a quarter of a mile from the town. Vessels when laden indeed can scarcely come within half a mile. On the shore lay vast piles of wood, destined to be conreyed to Stockholm for fuel. 
The country-people have, in every one of their mills, an instrument made of six or seven blades or hatchets, serving to cut chaff into small pieces in a trough, in order to grind it afterwards with their barley.

Rotkäl (Brassica oleracea *, Sp. Pl. 932, Napo brassica, or Stali-cabbage) is dried for winter use ; when it is boiled, and given with the liquor to the cattle.

The women at this place wear a hood, or neckcloth, as they call it, of grey walmal. cloth, but only in bad weather. It is tied with a black ribband in the fore part. When they ride on horseback, they carry the whip slung at their back.

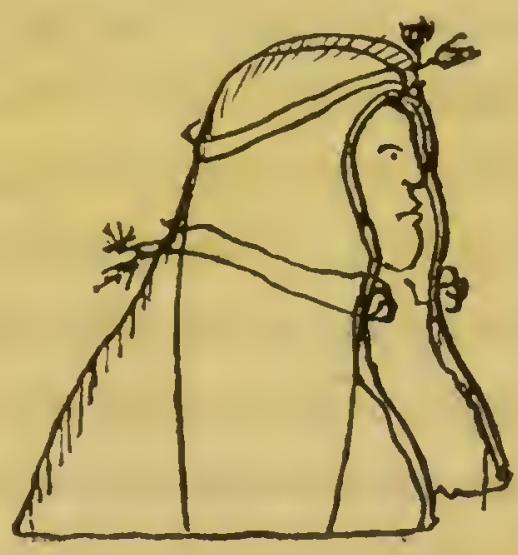


To stir up the pot, when boiling, they use a stick with sereral projecting bits of wood at the bottom, (not unlike a chocolate-mill,) which is rolled between their hands.

In the evening of this day I arrived at Wasa.

\section{September 23.}

I went to church at Wast, and visited. also the palace, situated on the south-west side of the city, the school, and other public buildings. This is a handsome little town enough. It is the residence of the governor.

Not far from the town, and indeed close to the walls, is a reputed copper-mine, the working of which was discontinued, after an excaration had been made to the depth of five or six fathoms. The ore has a glittering micaceous appearance, and gives a stain like black lead. The sand about it is a loose talc, as if spontaneously decomposed. I do not indeed believe that it contains any copper or other metal; which seems to have 
been the opinion of those who so soon gave over the pursuit.

The rustics here trust to three doctors, Beaver's-gall, Bear's-gall, and Pallavinus. (By a chemical sign annexed, it appears that Linnæus here meant brandy, but the word itself is not explainerl.)

This day being Sunday, I saw the girls all going bare-headed to church. They each, however, carried an oblong-oval hat, supported by broad coloured ribbands, the ends of which hung down.

\section{September 24.}

In my way from New Carleby to this place (the day before yesterday) I had observed a kind of plough in use, different from any I had before seen.: This was almost always drawn by a horse, seldom by an ox. The latter, when used, had the same harness as the horse, but without a girth. Over its back indeed passes a band like a saddle-girth, which is kept upon the neck of the animal to prevent the harness 
sliding forward; but for horses they use no such thing. See the figure.

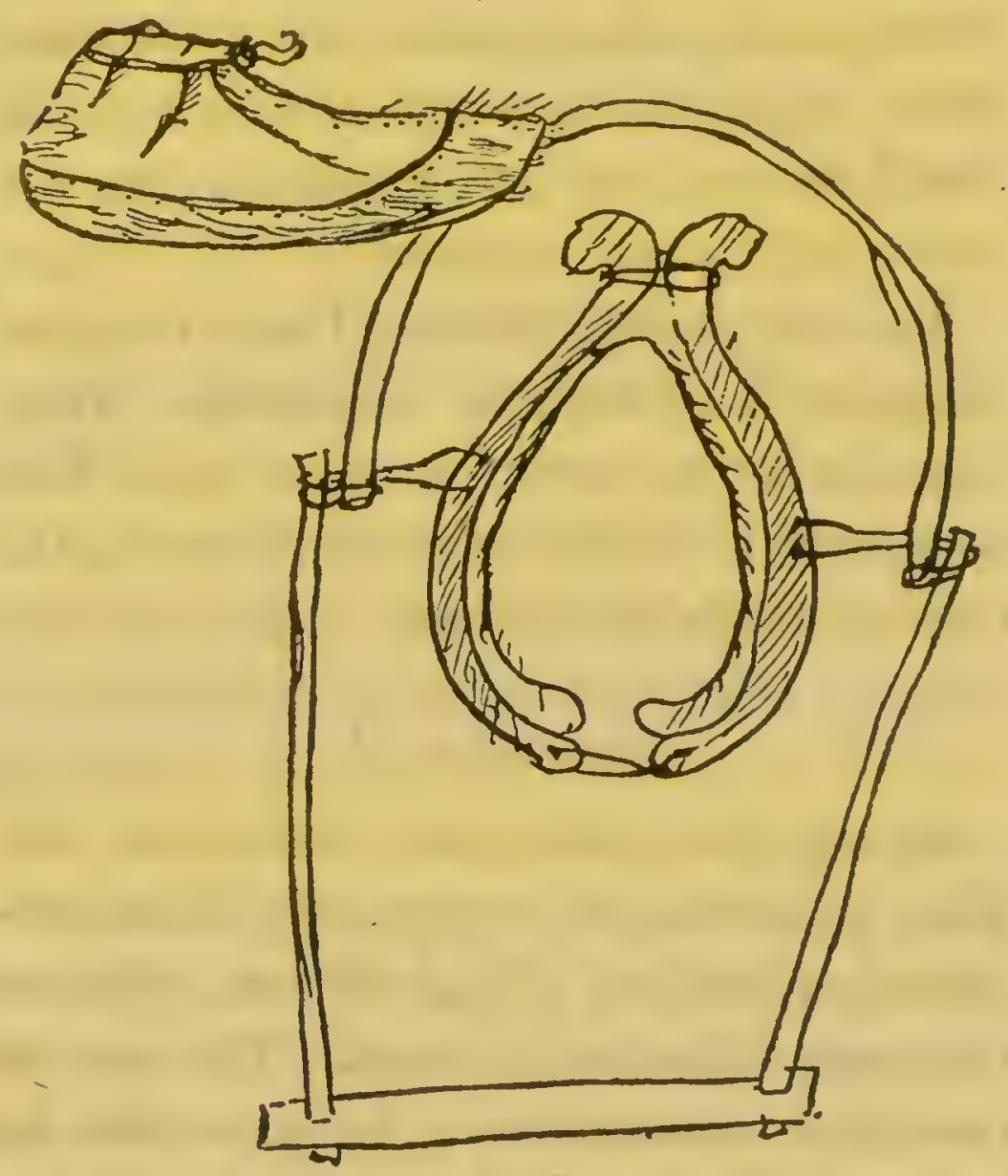

The shoes worn at this place in some measure resemble half-boots. The soles are of untanned leather, with the hair upon it; the upper leathers made of tanned seal- 
skin, and fied round the ankle with strings. (A representation of one of these shoes accompanies the last figure.)

Hypericum (perforatum), Scrophularia (nodosa), Bidens (cermua?) occurred to me here, for the first time in all my journey. The three species of Ribes (rubrum, alpimum and nigrum,) were in prodigious abundance.

\section{September 25.}

At sun-rise I took my departure from Wasa. The pines in the forest were stripped of their bark, so that vast tracts were covered with nothing but such naked trees. No more was left on each trunk, to the height of three ells or three and a half, than a small strip of bark, about the breadth of four fingers, generally on the north side, to prevent its being.... (here is a word not to be decyphered). The trees are left standing for six or. seven years afterwards, and are then cut down close to the roots, being also headed a little above the naked part. 
The heads or branches either serve for firing, or, as often happens, are left to rot on the ground.

Three miles below Wasa I recognised the Climbing Nightshade (Solanum Duls camara). In the town itself I had noticed (Leonurus) Cardiaca, and Henbane (Hyoscyamus niger). Near the shore grew Salix olecefolia with its berries, (Hippophä rhamnoides). It is known by the name of Finnber or Surberr, (Finn-berries, or Sour berries). The fruit is situated below the leaves, as in the Alder. The footstalks are two lines long. Berries bluntly oval, of a tawny orange-colour, three or four lines long, smooth, sour, having a watery pulp mixed with ochraceous matter. Seed solitary, roundish-oblong, slightly compressed, obtuse, attached by its lower edge to a membrane which enfolds it. When this cover is removed, the seed itself appears brown and polished, having a longitudinal groove at each side. The fishermen eat these berries bruised, 
by way of sauce to their fresh fish, but I thought them rather too acid.

\section{September 26.}

I passed Christina (Christinestadt), but before coming to that place, noticed at Nerpis a very extensire tract of land, which had formerly been a fine meadow, the soil being extremely good. But at present it was so entirely orerrun with tumps (originally perhaps formed of Carex caspitosa) that it produced little or nothing. These tumps were crowded almost over one another, and were overgrown by Polytrichum (Hail-moss), which had come to its full stature, and rendered most of them nearly black. There was scarcely room for the cattle to make their way to any food between the tumps.

In the passages of all the houses hung nets, used for catching bears. These are made of ropes of Lindenbast, (the inner bark of the lime-tree, Tilia europaa,) full as thick as a bridle or rein. The meshes VOL. II. 
when stretched are each three quarters of an ell wide. The height of the net is equal to the stature of a man. Such nets, supported by poles, are set up in a line of one hundred fathoms in extent, the lower side close to the ground. The bear is driven. into them by the people hunting him on all sides.

September 27.

This day I observed a mode of brewing in a kneading trough, which stood on a table, and its end being made so as to slide up and down, the wort is easily poured out.

Below the town of Christina, I first found the Lathyrus viciaformis (L. palustris), and Water Cresses, (Sisymbrium Nasturtium); also Campanula persicifolia and (Sedum) Telephium.

\section{September 28.}

I was glad when I had done with the very bad road which extends from the 
Lappfierd near Christina, to Hwisbofiahl, towards Biorreborg; a highway it cannot be called, for it is exactly like the road between the town of Unoea and-Granoen. (See v. 1. 14.)

Near Sastmola I first recognised the Acer (platanoides) and Filix fomina ras mosa (Aspidium Filix-famina?)

The road from Hwisbofiahl to Giolbohl lies along the coast. The grass here was remarkably tall, and full of all sorts of plants; as the Ribes insipidum (alpinum), called by the inhabitants Deglaer, in the greatest abundance. (Viburmum) Opulus and (Lonicera) $X$ ylosteum here first re-appeared after my long absence.

N. B. The shrub which Mr. Hojer informs us grows on this island, with blackishbrown berries, may perhaps be the Xylosteum, as the colour of the leaves seemed to agree very well. (Were it not for the above indication of the colour of the berries, it might, from the Flora Suecica, be suspected that Linneus had, in these two paraQ 2 
graphs, written by mistake Xylosteum for Periclymenum.)

The alpine Stone Bramble, Rubus saxatilis, was extremely plentiful; and the Cultivated Hop (IIumulus Lupulus), growing wild, afforded me great pleasure, as I contemplated its ingenious manner of curling round the Aspen trees (Populus tremula). Here also (Anemone) Hepatica, and the Cracca with toothed wings (stipulce) and striated flowers, (Vicia sylvatica,) as well as the Orobus rermus, once more greeted me. The grass with a dense spike-like panicle, whose stems serve for cleaning the inside of tobacco-pipes, (Agrostis arundinacea, grows copiously in this part of the country; and reached higher than my head. The marshes abound with Iris (Pseud-acorus) and with Cyperus (probably Scirpus maritimus).

The greater part of the road I had trarelled hitherto from Kimi lay so near the shore, that, even in the woody parts of it, the sea was frequently risible through the forests. 
September 29.

I travelled the whole of Michaelmas-day.

When a Finlander has fired at a bear, he immediately runs to one side, for the animal, if not killed, is sure to run directly forward, towards the smoke; by which means the man escapes out of his reach.

The peasants who reside near the cliffs or rising ground judge by the crows (Corvus (ormix), of the approach of bad weather; for these birds seek the marshy country in the evening before it comes on.

Ulvila churchyard seemed to abound with sculls. I reckoned forty of them in one heap. This churchyard is built round, after the old fashion.

On entering one of the stove-huts of the inhabitants here, it was so hot, that I thought my nose would have been burnt off. Nevertheless, the people within seemed comfortable enough, and the boys, clad in skins, were running up and down the couch. The stove is constructed like that 
of a bagnio in Smoland, but upon it is piled a great heap of flat stones, to the height of a man. The old women sit in these huts half naked.

Between Hyfoeda and Taftnen is a river almost navigable. In some parts, as I was told, it is nine fathoms deep, and in one place is a ferry across this river. Half a mile from hence southward, close to the road, between two small bridges which are near each other, I noticed a sand-hill of very fine sand, in differently-coloured strata, some white, others reddish-purple.

In the evening $I$ arrived at the town of Abo, which is as large as Orebro, and well built. It has often been ruined by the enemy, and often burnt down by accidental fires, which, if not occasioned otherwise, might easily happen from the stoves of the huts. I remarked that these stoves were less lofty than some I had seen, and that several stones lay loosely piled on one another abore the opening, which serve to retain the heat. 


\section{September 30.}

The Fimnish liquor called Lura is prepared like other beer, except not being boiled, instead of which red-hot stones are thrown into it. Hence its purgative quality from the iron.

Here I saw a flying squirel (Sciurus volans) from Tarasthia.

The long black rat, with a white lower lip, catches birds, both on trees and in the water. He holds fast by his claws, and bites with his four prominent teeth. The Finlanders call this animal Mink. (This seems to be Viverva Lutreola, Faun. Suec. ed. 2. 5.)

A quarter of a mile from the city is a mineral spring, of which Tillands has taken notice. (See v. 1. 43, note.) It is older than that of Mederi (near Vadstuna). The current is so strong that one of the burghers of the city has built a mill, to which the water is led, but it does not always go. Near the town a mine has lately been 
opened, containing iron here and there, with small quantities of pyrites. The mountain itsèlf is a black mica, immediately adjoining to the city.

The library here is miserable. There are two colleges close together.

\section{October 5 .}

I departed from $A$ bo. The corn-fields of Finland are beautiful, and resemble those of East Gothland in their wide extent and level surface.

There are regular ferry-boats at stated times to take passengers to the isle of Aland.

\section{October 6.}

I arrived at the place, near Brandoen, where I was to go on board the ferry-boat. The shore is a red rock. Passed over to the island of Aland, the whole of which consists of the same kind of red rock. The palace of Castelholm, at present falling fast into ruins, is built of this sort of stone. 
The women use for dyeing a sort of rock Lichenoides, of a brown stercoraceous colour, (perhaps Lichen stygins, or omphalodes,) which they boil in water with alum. But Walmal cloth, and stockings, are dyed without alum. Some add a little Arnotto (Bixa Orclana).

Shoes like short half-boots are worn here made of seal-skin.

\section{October 7.}

In the evening of this day I passed orer the plain of Aland. There were abundance of Finn-berries (Hippophäe rhamnoides) by the road.

\section{October 8.}

I sailed over the sea of Aland.

\section{October 9.}

Near Esbro an iron mine has lately been opened. About the church are sundry sepulchral monuments. I noticed on the small surrounding hills, as well as at Mu- 
sanger, rery finc aud lofty plants of juniper rescmbling cypresses, the branches erect and closc, assuming a conical or $\mathrm{py}$ ramidial figure.

\section{October 10.}

$\Lambda$ bout one o'clock in the afternoon $I$ arrived safe at Upsal.

To the Maker and Preserver of all things be praise, honour and glory for ever!

Some observations relative to the Seal, Jhoca vitulina.

There are two kinds (or varieties) of this animal. The Grŭb Siăl (Grey Seal) is the largest, of a grey colour, lighter, and slightly clouded on the back. The Witsure Siăl (Creek Scal) is smaller, black on the back, and rery cloudy or wavy at the sides. Otherwise there is no difference betreen them.

The whelp at its birth is perfectly white, being corered with white hair about an inch long, which it loses in four or five 
weeks, and becomes quite black. At the same period it acquires more activity and shyness thain at first. The upper fore teeth are six, very small, resembling those of a dog. The eye-teeth slightly enlarged at: their outer edge, as in the dog, and furnished with a little notch at their base. Grinders six. Whiskers remarkiably large. There are two nipples a little below the navel, which the fomale has a power of drawing in, so as to leave holes large enough to admit the finger. She lets them out at pleasure to her young one.

The seal lies on its back while sleeping, either on the ice or on rocks. They couple soon after the feast of St. Matthew, September 21 ; and the grey seal brings forth its young in January, the creek seal in February. The male runs round and round the female many times, with a yelping noise, being very careful not to be observed.

When the female has young, the male is very savage, and continualiy attends to 
protect her. She brings forth but one at a birth, which at first is dull and stupid, casily canght. If thrown into the water, however, he exerts himself with some activity, and returns to the shore, not having as yet acquired any shyness. But by the time all his first coat of white hair is fallen off, he begins to be timid. The growth of the young seals is very rapid.

The seal, when out of the water, can hardly distinguish objects at half a quarter of a mile's distance at the utmost. I3ut in foggy and dull weather he secs botter than in sunshine. He never remains in the water during moon-light nights. His licaring is acute though he has no external ears, and his scent is also very quick. He can remain under water for nearly half a quarter of an hour; but by that time he must, at the peril of his life, come to the surface to breathe, which he often does within a fathom of the shore, and he afterwards spouts out water.

Nets for catching seals are set right out 
into the sea, from some promontory, to the distance of twenty fithoms. These are examined every morning, to see what is caught. They are chiefly set from St. Bartholomew (August 24), when the moon is in her wane, till orer St. Matthew's day, September 21.

Grey seals are hunted in winter till Lady-day. They lie upon the ice, often in great numbers, close to a hole which they have made in it. When they come out of the water by this opening upon the surface of the ice, the water they bring with them freezes about its margin, so that in time the edges become elevated, and it looks like at well. If it should frecze over, they travel to the south-west, till they can get at water, always procceding straight forward, even though they meet with mountains in their way; and they return in the same direct line back again. The hunters go with large poles, carefully approaching the creck seal till they get near enough to fire at him before he is aware. 'The grey 
238 OBSERVATIONS ON SEALS.

seal is taken with a sort of hook or haspoon.

The seals are able to penetrate through the ice from beneath, lying on their backs under water, be it ever so thick, but cannot make their way into it from above.

NAD OH TUE TOUR. 


\section{$.1 P$ PENDIX.}

\section{N'I.}

\section{A BRIEF NARRATIVE}

\section{OF}

\section{A JOURNEY TO LAPLAND,}

Undertaken with a View to Natural History, in the Year 1732, at the Expense of the Royal Academy (of Upsal); by Charles Linnaeus, Student of Physic and of Natural History, as drawn up by Himself to lay before the said Academy.

Tur Royal Academy of Sciences having, last Spring, permitted my humble memorial to be laid before them, respecting the project of a journey to Lapland, with a view to the improvement of natural history; and having honoured the same with their approbation, appointing me to undertake 
the expedition, I feel it my duty, after having accomplished my journey, most respectfully to present to the Academy a narrative thereof.

For the sake of brevity and clearness I shall divide my subject into three parts.

1 st, A journal of my tour.

2d, The expenses incurred.

3d, The advantages likely to accrue.

I. TIIE JOURNAL. May 12, 1732.

Haring received my instructions from the Royal Academy of Sciences, with a passport from the Government, and haring prepared every thing necessary for my journey, I set out immediately at eleven o'clock, from this place (Upsal), carrying with me nothing but what was absolutely necessary, in order that I might not be detained or interrupted, in case of not being able always to procure a horse, but might occasionally pursue my way on foot. As the summer secmed to be fast advancing, I 
thought it not advisable to lose time by the way, nor to stray far from the road, in the early part of the tour, but only to observe attentively what readily presented itself, that I might reach Lapland with all possible dispatch.

\section{May 13.}

By eleven o'clock I arrived at Gefle, where I was obliged to stay all that day, for it was erening before I received from the governor of the province (of Gestrickland) the requisite passport, which was accompanied by orders to all the public officers in his district to give me all requisite assistance to penetrate, if possible, into Asila Lapmark.

\section{May 14.}

Owing to the above delay, and my attending morning service the next day at Gefle church, I could not quit that place till one o'clock. Proceeding without stopping to Hudwickswald, I there merely 
spoke a few words to Mr. Broman the clergyman, and pursued my way to Knorby Knylen, the highest mountain in $\mathrm{Me}$ delpad, from whence I went to Sundswall, and further. In my way I examined a cave formed by nature in a very hard rocky mountain, formerly a retreat for thieves and highwaymen.

I was so unfortunate, in my journey through Medelpad, as not to meet with a single horse that did not tumble with me several times, in consequence of which I was at one time so severely hurt as to be scarcely able to remount. Having already collected together a number of stones and minerals, which were no less burthensome than unnecessary to carry along with me further, I rode to Hernosand, where I left these incumbrances. I did not, however, stay there above two hours.

\section{May 20.}

At length I reached the famous mountain of Skula in Angermanland, at the very 
top of which is a large grotto, so neatly formed by nature that art could scarcely have excelled it. This grotto was represented to me as quite inaccessible, and it was said that not more than two or three persons had ever been there; nor was it without great difficulty that I prevailed on two men to accompany me, every body decming the project impracticable. As we climbed up towards it, we sometimes crept forwards, sometimes shid back again. Now we mounted a considerable way by catching hold of branches and roots of trees, and then, meeting with steep inaccessible rocks, were obliged to turn back. After following one of my guides for about two hours, I thought the other seemed to make more progress; which induced me to go after the latter. I was scarcely got two ells out of my former path, than the man whose track I had left loosened a large stone with his foot, which fell on the very spot I had quitted, with such violence, that I was surrounded by fire and smoke, and should I2 2 
certainly, but for the protecting hand of Providence, have been crushed to pieces. We reached the grotto at length, after much labour and trouble, and descended. the mountain with much greater facility. Laying hold of the tops of spruce firs which grew close to the rocks, we slid down upon them, dragging them after us down the precipices.

\section{May 23.}

I at length, after twelve days journey, reached Umoea.

It had originally been my design to go to Asila Lapmark, in order to observe what plants are able to endure the very hard winters of that region, but I was obliged to change my plan. The summer would not have been long enough, nor my stock of money sufficient to enable me to reach that most northern part of the country, where the severity of the climate is augmented by the cold north wind and the rast snowr mountains. I applied, 
therefore, to baron Grundell, governor of Umoca, for a passport to the nearer parts of Lapland, which was immediately granted. This gentleman showed the greatest readiness to befriend me, and appeared to take much interest in the success of my undertaking. He gave such orders as might cause the public officers in Lapland to lay no obstacles in my way, but rather to assist me by every means in their power. He himself gave me much curious information, and showed me his own garden, that I might observe what plants would stand the winter here: concluding by expressing, in the most flattering terms, his approbation of my appointment.

\section{Maly 25.}

The following morning I set out on my way towards Lapmark. Leaving the highway, I came to one of the most unpleasant roads I ever travelled. It was covered with stones, betwixt which were thick en- 
tangled roots of trees, and among them were deep holes full of water. The whole ground was a marsh, which the frost was at this time just about quitting. Large pine-trees, that had been blown down in the course of the stormy winter, frequently crossed my path; and the more flexible birches, weighed down by the snow, interrupted my course on all sides. I frequently came to such steep heathy places that my horse could scarcely climb or descend them, and in the bottoms between them were marshy tracts, with rivulets destitute of bridges, so that my beast slipped down several times; and as I passed the streams, the water reached up to my saddle. I then regretted, what I had in the former part of my journey so much detested, travelling on the high-way on these stumbling horses, and would rather have descended the steepest hill in Angermannia than have chosen the present road, for at every step the horse took, I thought he would have fallen. 
In the evening of

$$
\text { May 2s, }
$$

however, I arrived at Genom, the last village in Westbothland, seven miles from the great road which leads westward from Umoea. Not having reposed since I left the place last mentioned, I slept here all night.

$$
\text { May } 29 .
$$

The next morning I proceeded in a boat up the river of Umoea as far as Lycksele church, which is the first in Umoean Lapmark, and situated five miles distant fiom Grano. This was Whitsun-eve.

$$
\text { May } 30 .
$$

Being Whitsunday; I determined to stay here. Indeed Mr. Gran the minister of the place* (Pastor Gran in the original) wished me to wait till the next Sabbath-

* In the Journal, vol. i. 101, Linnæus speaks of Mr. Oladron as the curate of Lycksele, and his wife. 
day, as he did not think it advisable for me to proceed, so as to come suddenly among the Laplanders, before he had made my design known from the pulpit. He was apprehensive that I might meet with the same accident as his own wife had done, who coming unexpectedly upon these people, had a fire-lock presented to her breast. Notwithstanding this, the rise of the water in the river, in consequence of the adrancing summer among the Alps, was so rapid, that I was on that account induced to hasten my departure, after having engaged one of the colonists to accompany me by water to the nearest habitation of some one of the native Laplanders.

\section{May 31.}

The divine service of this day being over, I left Lycksele, taking with me only three loaves of bread, and some rein-deer tongues, by way of provision. I presumed that I should procure among the Laplanders flesh of the rein-deer, cheese, milk, fisli, 
fowl, \&c. Nor, indeed, could I well take any thing more at present; for, whenever we came at any shoals or falls in the river, it was necessary for my companion to take our boat on his head, over mountains and valleys, so that I had not only my own luggage to carry at such times, but his likewise.

\section{June 1.}

Having by morning come within the territories of the nearest Laplander, we left our boat on the shore of the river, and went in search of this man through the wild forests, where we saw no more traces of roads or enclosures than if the country were entirely uninhabited. We met, however, with several deserted huts, where he had at one time or other resided.

Being exceedingly tired with this walk, I was glad to repose myself here in the desert, while my Finland conductor went in search of my future guide. Nor was I without considerable fears that this man, 
when he had met with the Laplander, might not be able to find me again. However, about noon he returned, accompanied by a Laplander, who took charge of me, inviting me home to his hut, where he treated me with fish, and fresh water.

I was afterwards conducted from one Laplander to another, till I came to a part of the river, about twenty-fire miles above Lycksele. I shall not dwell on the inconveniences I was obliged to undergo every time we had to seek for any of the Laplanders, while I was quite destitute of provisions. These poor people themselves had, at this season, nothing but fish to eat, as they had not yet begun to slaughter their reindeer, nor to go a fowling; neither had they, as yet, milked any of their reindeer.

\section{Jine 2.}

On coming to the place just mentioned, we found it impracticable to proceed by water, the river being so rapid, and so much impeded by falls, that we were 
obliged to undertake a walk of a few miles further, which I was told would bring us to a more navigable stream. After walking for some time, a fen or marsh lay before us, seemingly half a mile broad, which we had to cross. At every step the water was above our knees, and the ice was at the bottom. Where the frost was quite gone, we often sunk still deeper. When we had traversed this marsh, we sought in vain for any human creature, and were therefore under the necessity, a little further on, of crossing another bog, still worse than the former, and a mile in extent. I know not what I would not rather have undertaken than to pass this place, especially as the elements were all adrerse, for it blowed and rained violently.

\section{June 3.}

By four o'clock this morning, having conquered all our difficulties, we still could not meet with any Laplander. I was so fatigued that I could proceed no further 
without some repose. We therefore made a fire; and having dried my clothes, I lay down by the side of it, in hopes of taking a little rest. But in this I had no success. The fire scorched me on one side, while the cold north wind pinched me on the other; and the gnats so stung my hands, face, and legs, that it was impossible to sleep. Thus I remained in expectation of my Lapland conductor, who had set out in search of another, till two o'clock in the afternoon. I could not help thinking how miserably I might have to end my days here, in case he should think proper to desert me entirely. At length, however, he returned, bringing with him a little black-looling woman, whose hair hung loose about her shoulders, with a red cap upon her head. I scarcely think that any poet could have described a fury so hideous as this woman. She addressed me in Swedish to the following effect. "Oh, thou poor man! what misfortune can have brought thee into my country? Seest thou what miserable living 
we have? I have never yet seen any stranger here in summer. Whence dost thou come, and whither dost thou intend to go?" Haring tasted nothing for four days past but a little fresh fish, without any bread, I asked her, seeing a small kettle in her hand, what she could give me to eat. She immediately set about boiling a pike which she had brought with her; but when I was going to taste it, I observed heaps of vermin between the gills, which made meloathe it altogether, and rather continue to fast, though my strength suffered much. This woman informed me there was no boat to be had on the next river, and tlat I had only to return the way I came; which words were like a stroke of thunder to me. I know not any thing I would less willingly have undertaken than to traverse again these Stygian marshes, which were now not to be avoided. However, this good woman conducted us to a side path, whereby we avoided about half a mile of the way we had come. In traversing the forest, we 
arrived at a shed, supported by four posts, and covered with a roof. Here hung some clothes, and a small rein-deer cheese, which last I immediately wished to obtain. But the woman refused, saying she should want it herself for the next holiday. My hunger was such, that I could not lose sight of this cheese, and I was induced to offer her any thing she was pleased to ask for it, telling her I verily believed I should hardly survive another day if I had it not. At length she complied, and the cheese proved afterwards of the most signal ser$\forall$ ice to me. We then took leave of our female companion, and began to measure back our steps. I was thus obliged to returin by the course of the river, having, with the thoughtlessness of youth, undertaken more than it was possible to perform.

We continued our voyage down the river, being carried with great velocity by the current, the whole of the next day. At length coming to an island, the Laplander failed in his attempt to weather it, 
and the boat, striking against a rock, was dashed to pieces. We both found ourselves in the water; but the depth being inconsiderable, we soon landed on the island. My conductor lost not only his boat, but a hatchet and pike. I lost two stuffed birds, one of them a large Heron (Ardea cinerea?) which was black with a white breast; the other a Red-bird, or Grousach, as the Laplanders call it, (Corvus, or Lanius infaustus, see r. 2. 109.) It was with great difficulty we got from this island to the shore. The sun shone warm; and after having wrung the water out of our clothes, we walked on for about a mile, along the bank of the river, amongst thickets and bogs, till we came in sight of a colonist, who was fishing for pike. He gave me some provision, and conducted me to Grano, where I only stopped to rest one night, and on the evening of the 3th of June arrived at Umoea.

\section{June 12.}

Early this morning I set out by land 
towards Pithoea, where I arrived after two days journey, for the night was as pleasant for travelling as the day. Here I met with kind entertainment from $\mathrm{Mr}$. Solander, the principal clergyman of the place.

\section{June 19.}

I went out to sea in a boat for some. miles, to explore the neighbouring coast and islands, and returned at length to the new town. Here however I made no long stay, but proceeded in one day from thence to Lulea. I was anxious to lose as little time as possible, being rery desirous of reaching the alps of Lulean Lapland time enough to see the sun above the horizon at midnight, which is seen to greater advantage there than at Tornea.

\section{June 2.5.}

Taking leave of the town, I embarked on the river of Lulea, which I continued to narigate upwards for several successive days and nights, having good accommodation 
both as to food and boat. The boats here are excellent, far unlike those in the district of Umoean Lapland, which are, in a manner, only sewed together, so that a foot set on one of their sides is sufficient to stave them; and if the passengers are not careful how they sit down, the boat is overset. After three days and three nights, we reached Quickjock, situated close to the alps. Here I received from the famous wife of the curate $\mathrm{Mr}$. Grot provisions sufficient to last me for eight days.

\section{July 6.}

After several days' travelling, on the evening of July 6 th I ascended Wallavari, the first mountain of the alps on this side, which is indeed of a very considerable height. My companion was a Laplander, who served me both as servant and interpreter. In the latter capacity his assistance was highly requisite, few persons being to be met with on these alps who are acm VOL. II. 
quainted with the Swedish language; nor was I willing to trust myself alone among these wild people, who were ignorant for what purpose I came. I had already suffered much in the Lapland part of Umoea for want of knowing the language. Nor was my companion wanted less to assist me in carrying what was necessary, for I had sufficient incumbrances of my own, without being the bearer of our provisions into the bargain.

On my first ascending these wild alps, I felt as if in a new world. Here were no forests to be seen, nothing but mountains upon mountains, larger and larger as I advanced, all covered with snow. No road, no tracks, nor any signs of inhabitants were visible. The verdure of summer seemed to shun this frozen region, retiring into the deepvalleys between the mountains. I saw very few birds, except some Ptarmigans, which the Laplanders call Cheruna (I'etrao Lagopus), running with their young along the vales. The delightful season of 
spring, whose cheering influence on man and all living nature I had so lately experienced in the beginning of my journey, seemed an alien here. The declining sun never disappeared sufficiently to allow any cooling shade, and by climbing to the more elevated parts of these lofty mountains, I could see it at midnight above the horizon. When I cast my eyes over the grass and herbage, there were few objects I had seen before, so that all nature was alike strange to me. I sat down to collect and describe these vegctable rarities, while the time passed unperceived away, and my interpreter was obliged to remind me that we had still five or six miles to go to the nearest Laplander, and that if we had a mind for any rein-deer meat, we ought to bestir ourselves quickly. We proceeded therefore up and down the snowy hills, sometimes passing along their precipitous sides, which was the most difficult travelling of all, and for many a long way we walked over heaps of stones. About the 
evening of the following day we reached the nearest spot where any Laplander was at that time settled. The man we met with gave me a very good reception, and furnished me with a couple of rein-deer skins to sleep between. Immediately after my arrival, the herd, consisting of seven or eight hundred head of réin-deer, came home. These were milked, and some of the milk was boiled for my entertainment, but it proved rather too rich for my stomach. My host furnished me with his own spoon, which he carried in his tobaccobag. On my expressing a wish, through my interpreter, to have the spoon washed, my Lapland friend immediately complied, taking a mouthful of water, and spitting: it over the spoon.

After having satisfied my hunger, and refreshed myself with sleep, I steered my course directly South-west, towards the alps of Pithoea, proceeding from thence to the lofty icy mountains, or main ridge of the country. A walk of scarcely above 
four or five miles further brought me to the western edge of this ridge, for I was desirous of examining that side of the mountains, to see how it agreed with the eastern part. I had no sooner arrived at the icy mountains than a storm overtook me, accompanied by a shower of thin pieces of ice, which soon formed an icy crust over my own clothes and those of my conductor. The severity of the cold obliged me to borrow the gloves and lappmudd (coat of rein-deer skin) from the man who accompanied me. But the weather proved more farourable as soon as we had crossed the summit of the ridge. From hence the verdant appearance of Norway, lying far beneath us, was very delightful. The whole country was perfectly green, and, notwithstanding its vast extent, looked like a garden in miniature, for the tallest trees appeared not above a span high. As we began to descend the alps, it seemed as if we should soon arrive at the lower country, but our calculations 
were very inadequate to what we found it: actual distance. At length, however, we reached the plains of which we had enjoyed so stupendous a prospect. Nothing could be more delightful to my feelings than this transition, from all the severity of winter, to the warmth and beauty of summer. The verdant herbage, the sweetscented clover, the tall grass reaching up to my arms, the grateful flavour of the wild fruits, and the fine weather which welcomed me to the foot of the alps, seemed to refresh me both in mind and body.

Here I found myself close to the sea coast. I took up my abode at the house of a ship-master, with whom I made an agreement to be taken in a boat, the following day, along the coast. I much wished to approach the celebrated whirlpool, called the Maelstrom, but I could find nobody willing to venture near it.

We set sail the next morning according to appointment, but the wind proved con- 
trary, and the boat-men wrere, after a while, exhausted with rowing. Meantime I amused myself in examining various petrifactions, zoophytes, and submarine plants of the Fucus tribe, which occupied every part of the coast. In the evening I arrived at the house of $\mathrm{Mr}$. Rask, the pastor of Torfjorden, who gave me a kind reception.

Next day we proceeded further on our voyage; but the contrary wind exhausted our patience, and we veered about, soon reaching the place from whence we had first set out, the wind being directly in our favour for that purpose.

On the following morning I climbed one of the neighbouring mountains, with the intention of measuring its height. While I was reposing in perfect tranquillity on the side of the hill, busied only in loosening a stone which I wanted to examine, I heard the report of a gun at a small distance below. I was however too far off to receive any hurt, so, thanlis to 
Providence, I escaped, but my alarm may be easily imagined. Perceiving the man who had fired the gun, I pursued him to a considerable distance, in order to prevent his charging his piece a second time, and I determined never to go there again without some protection. I inquired who it could be that had made this unprovoked attack, but I found it impossible to gain any information on the subject.

On the 15 th of July* we set out on our return, and that whole day was employed in climbing the mountains again, to our no small fatigue and exhaustion, the ground we had to pass over being so extremely steep as well as lofty. When we reached the cold snowy mountains, indeed, we had sufficient opportunity to cool ourselves.

From hence we turned our course towards the alps of Tornea, which were de-

* The manuscript says July 1st, but this does not agree with the original journal, which therefore I have followed. See the first page of this volume. 
scribed to me as about forty miles distant. What I endured in the course of this journey is hardly to be described. How many weary steps was I obliged to set to climb the precipices that came in my way, and how excessive were my perspiration and fatigue! Nor were these the worst evils we had to encounter before we reached Caituma. Sometimes we were enreloped with clouds, so that we could not see before us; sometimes rivers impeded our progress, and obliged us either to choose a very circuitous path, or to wade naked through the cold snow water. This fresh snow water however proved a most welcome and salutary refreshment, for without it we should never have been able to encounter the excessive heat of the weather. Water was our only drink during this journey, but it never proved so refreshing as when we sucked it out of the melting snow. Having nearly reached the Lapland village of Caituma, the inhabitants of which 
seemed perfectly wild, running away from their huts as soon as they perceived us approaching, from a considerable distance, I began to be tired of advancing further up into this inhospitable country. We had not at this time tasted bread for several days, the stock we had brought with us being entirely exhausted. The rich milk of the reindeer was too luscious to be eaten without bread, and the ordinary or second-rate cheese occasioned such a degree of costiveness as I could no longer endure. I determined therefore to return towards Quickjock, which was forty miles from this spot. In the course of my journey thither, walking rather carelessly over the snow, without noticing a hole which the water had made, I fell through the icy crust into the deep snow. The interpreter and guide were totally unable to assist me, the cavity in which I lay being very steep, and so hollowed out by the water that it surrounded me like a wall. It was not in 
their power to reach me without a rope, which they luckily were able to procure to drag me out of the hole. I had received a blow on my thigh in the fall, the effects of which I felt for a month afterwards. One of my guides had met with a similar accident but a week before.

At length we arrired at Quickjock, after having been four weeks without tasting bread. Those who have not experienced the want of this essential support of life, can scarcely imagine how hard it is to be deprived of it so long, even with a superfluity of all other kinds of food. I remained four days at Quickjeck to recruit my strength, and afterwards descended the river again to Lulea. There being no boat to be had north of Purlijaur, we were obliged to construct a raft for ourselves. Our voyage was very perilous, for the wind and current both combined to overset us, so that it was not without the greatest exertion we saved ourselves, and it being night, nobody heard our cries for assistance. 
The next day I was conducted to the river of Calatz, to see the manner of fishing for pearls, and on the 30th of July arrived at Lulea.

Here I rested for a day or two, then proceeded to Tornea, and from thence to Kimi, and some way up the river of that name. Afterwards I entered East Bothland; but not understanding the Finnish language, I found it inconvenient to proceed, and preferred returning four miles back again. I made several excursions to an adjacent island. At the town of Calix I became acquainted with the judge of a neighbouring district, and we accompanied cach other to Tornea, from whence I proceeded in a boat to Kengis, Jonesrando, and within four miles of Juckesceni; but as the frost was beginning to set in very hard, it being late in autumn, and there being nothing, as far as I could discover, very remarkable to sec, I descended the river again in the same boat, and had a quick passage back. Having noted down 
the Finnish names for such articles as I should be most likely to want at the inns, I ventured once more to enter East Bothland, in order to pursue my journey that way homeward. I considered that in a new country there is always something new to be seen, and that to travel the same road I had come, would probably afford but little entertainment or instruction. I had still less inclination, at this advanced season of the year, to encounter the ha* zard of a sea royage. Several merchants who wanted to sail from Tornea to Stockholm, had long been waiting for a fair wind.

I therefore pursued my way along the coast through East Bothland and Finland, visiting Ulea, Brakestad, Old and New Carleby, Wasa, Christina, Biorreborg and Abo, remaining four days at the place last mentioned. I then went by the post yacht to Aland, crossed the sea of Aland, and on the 10th of October reached Upsal.

The whole extent of my journey amounts 
to 633 Swedish miles (about 3798 English miles) as appears by my itinerary subjoined.

Miles.

From Upsal to Umoea - $\quad$ - $\quad$ - 60 Umoea to Lycksele - $\quad$ - $\quad$ - 12

Lycksele to the upper part of Lapmark 25 From thence again to Umoea $\quad-37$ From Umoea to Pithoea _ $\quad$ - 22 Pithoea to Longoen - $\quad$ - 5 Back again to Pithoea $\quad-\quad 3$ From thence to Lulea $\quad$ - 5 Lulea to Quickjock - _ $\quad$ - 33 Quickjock to the alps of Pithoea - 25 From thence to the Norway coast - 10 Excursion by sea, and back again, - 14 From Norway to Caitum - 40 From Caitum to Quickjock $\quad-40$ Quickjock to Tornea $\quad$ - $\quad-47$ Tornea to Kimi - - - 5

From hence to Maxaniemi - $\quad 5$ Maxaniemi to Calix _ $\quad$ - 9 Calix to Kengis - - $\quad$ - 32 Kengis to Jonesvando _ - 40 Jonesvando to Tornea _ $\quad$ - 26 Tornea to Abo Abo to Upsal

$-100$

$-40$ 
(The account of the expenses of this journey, and observations on the advantages to be derived from it, both promised in the beginning of this "brief narrative," are not found in the manuscript.) 


\section{APPENDIX.}

\section{No II.}

$\mathrm{T}_{\text {н }}$ following extract, from Dr. Wahlenberg's "Observations made with a view to determine the height of the Lapland Alps," p. $45, \&$ c., was translated from the Swedish by the late Mr. Dryander, who kindly communicated it to the editor, expressing a wish that it might accompany the present publication. To fulfil this desire is now become a duty. It is with a melancholy satisfaction I here subjoin the last communication I ever received from this excellent and learned pupil of Linnæus, to the work of his master. Many remarks from him have assisted me in the course of this undertaking, and if I could have submitted the whole to his inspection before it went 
to press, many inaccuracies, which a foreigner could scarcely avoid, might have been corrected by a native Swede, a man too so supremely accurate, and so conversant with every part of the subject. But this the various and unremitting employments of my deceased friend rendered im- practicable, and I could only take advantage of what he had it in his power to bestow, in casual conversations, or in answer to the questions I was now and then obliged to ask him, such as he was ever ready, on all occasions, to satisfy, because, to use his own words, he knew they were "likely to be of use."

The following remarks of Dr. Wahlenberg display a singular acuteness of observation. They are a complete picture, drawn by a masterly hand, not only to the adept in Natural History, but to every one who has the least taste for beholding the face of Nature, under its most striking and unusual aspects. The able author is, as yet, but slightly known to English readVOI. II. 
ers, even in the more technical part of his science. What we are now to lay before them gives a promise of his taking a high rank amongst writers of a superior and more generally interesting class, one of those in short who touch upon no subject without enriching it.

Dr. Wahlenberg's remarks are divided into eight sections, each of which describes a separate line of elevation.

1. On approaching the Lapland Alps (Fjaill), we first arrive at the line where the Spruce Fir, Pinus Abies, ceases to grow. This tree had previously assumed an unusual appearance ; that of a tall slender pole, covered from the ground with short, drooping, dark branches; a gloomy object in these desolate forests! The Rubus arcticus had already, before we arrived at this point, ceaser to bring its fruit to maturity. With the Spruce we lose the Rosa cinnamomea, Convallaria bifolia, \&c.: and the borders of the lakes are stripped 
of their ornaments of Arundo Phragmites, Lysimachia thyrsiftora, Galium boreale, and Carex globularis. Here is the true station of Tussilago nivea (Willd. Sp. Pl. v. 3. 1970.) The last bearer-houses are seen in the rivulets, and no Pike nor Perch is to be found in the lakes higher up. The boundary of the Spruce Fir is $\$ 200$ feet below the line of perpetual snow, and the mean temperature is about $3^{\prime \prime}$ of Celsius's thermometer ( $37 \frac{1}{2}$ of Fahrenheit).

2. Scotch Firs (Pinus sylvestris) are still found, but not near so tall as in the lower country. Their stems here are low, and their branches widely extended. Here are seen the last of Ledum palustre, Salix pentandra, Veronica serpyllifolia, \&c. The bogs have already a very steril appearance. Near the utmost boundary of the Scotch Fir grows Phaca alpina. Higher up are hardly any Bears to be met with, and the berries of Vaccinium Myrtillus (the Bilberry) do not ripen well. Salmo Lavaretus (the Gwiniad), and S. Thymallus (the Grayling), 
soon after disappear from the lakes. The upper limit of this zone, when the Scotch Firs cease, is 2800 feet below the line of perpetual snow, and the mean temperature about $2,0.5$ of Celsius ( $36 \frac{1}{2}$ of Fahrenheit.) A little below this point, or about 3000 feet before we come to perpetual snow, Barley ceases to ripen; but small farms, the occupiers of which live by grazing and fishing, are met with as far as 400 feet higher, for instance, Naimaka in Enontekis, and so far also potatoes and turnips grow large enough to be worth cultivating.

3. Beyond this the dwarf and stunted forests consist only of Birch. Its short thick stem, and stiff, widely spreading, knotty branches, seem prepared to resist the strong winds from the alps. Its lively light green hue is delightful to the eye, but evinces a weakness of regetation. These Birch forests soon become so low, that they may be entirely commanded from the smallest eminence. Their uppermost boundary, where the tallest of the 
trees are not equal to the height of a nan, is 2000 feet below the line of perpetual snow. This zone is thcrefore much wider than the preceding. Long before its termination Alnus incana, Prunus Padus, and Populus tremula, were no more to be scen. A little before the Birch ceases, we miss the Sorbus Aucuparia (Pyrus Aucuparia, Fl. Brit.) which for some time had not presented us with any fruit; the Rubus arcticus already likewise barren; Erica vulgaris, Aconitum lycoctonum, \&c. Where the Birch forest becomes thinner, the reflection of the heat from the sides of the mountains is the strongest. Here in many spots we find the vegetation of Sonchus alpinus, Struthiopteris, and Aconitum lycoctonum remarkably luxuriant. The drier spots now become covered with Lichen rangiferinus. Tussilago frigida and $\mathrm{Pe}$ dicularis Sceptrum-Carolinum have their place to the utmost boundary of the Birch. Thus far only Charr (Salmo alpinus) is 
found in the lakes, and higher up all fishing ceases.

4. All mountains above this limit are called Fjaill (Alps). Near rivulets and on the margins of bogs only, is found a little brush-wood, consisting of Salix glauca, whose grey hue affords but little ornament to the landscape. The lower country is covered with the dark-looking Betula nana, which still retains its upright posture. A few Juniper bushes, and some plants of Salix hastata, are found scattered about. Every hill is covered with Arbutus alpina, variegated with Andromeda ccerulea and Trientalis europcea. The more boggy ground is decorated with Andromeda polifolia in its greatest beauty, and Pedicularis lapponica. On the sides of the mountains, where the reflected heat has the greatest power, grow Veronica alpina, Viola biflora, Pteris crispa, and Angelica Archangelica. This zone extends within 1400 feet of the line of perpetual snow. 
The Glutton (Mustela Gulo) goes no higher than this. The berries of Rubus Chamamorus still ripen here, but not at a greater degree of elevation.

5. Now no more brushwood is to be seen. The white Salix lanatu is not above two feet high, eren about the rivulets, and Salix myrsinites is of still more humble growth. Betula nana occupies the drier situations, but creeps entirely upon the ground. The hills are clothed with the rather brown than green Azalea procumbens and Azalea lapponica, which give this zone its most peculiar feature. Verdant spots between the precipices, where the sun has the greatest power, produce l.ychnis apetala, Erigeron uniflorum, Astragalus leontinus* and montanus, with Ophrys alpina. In boggy places Aira alpina, Carex ustulata, and Vaccinium uliginosum are observable. The only berries howevor which ripen at this degree of elevation, are

* Jacq. Ic. Rar. t. 154. Willd. Sp. Pl.v. 3. 1287. 
those of Empetrum nigrum; but these are twice as large as what grow in the woodlands, and better flavoured. The upper boundary of this zone is 800 feet below the line of perpetual snow. The Laplanders scarcely ever fix their tents higher up, as the pasture for their reindeer ceases a very little way above this point. The mean temperature is about +1 " of Celsius (34 of Fahrenheit).

6. Next come the snowy alps, where are patches of snow that never melt. The bare places between still produce a few dark shrubby plants, such as Empetrum nigrum, but destitute of berries, Andromeda tetragona and hypnoides, as well as Diapensia lapponica. Green precipices exposed to the sun are decorated with the vivid azure tints of Gentiana tenella and nivalis, and Campanula uniflora, accompanied by the yellow Draba alpina. Colder and marshy situations, where there is no reflected heat, produce Pedicularis hirsuta and flammea, with Dryas octopetala. This 
zone extends to 200 feet below the limits of perpetual and almost uninterrupted snow.

7. Beyond it perpetual snow begins to cover the greatest part of the ground, and we soon arrive at a point where only a few dark spots are here and there to be seen. This takes place on the Alps of Quickjock at the elevation of 4100 feet above the sea; but nearer the highest ridge, and particularly on the Norway side of that ridge, at 3100 feet. Some few plants, with succulent leaves, are thinly scattered over the spongy brown surface of the ground, where the reflected heat is strongest, quite up to the line of uninterrupted snow. These are Saxifraga stellaris, rivularis and oppositifolia, Ranunculus nivalis and glacialis, Rumex digynus, Juncus curvatus * and Silene acaulis. The mean temperature at the boundary of perpetual snow is $+0,04$ of Celsius, (32 $\frac{3}{4}$ of Fahrenheit).

* We know not what species the author intends by this name. 
8. Above the line of perpetual snow, the cold is occasionally so much diminished, that a few plants of Ranunculus glacialis, and other similar ones, may now and then be found, in the clefts of some dark rock rising through the snow. This happens even to the height of 500 feet above that line. Further up the snow is very rarely moistened. Yet some umbilicated Lichens (Gyrophorc), \&c., still occur in the crevices of perpendicular rocks, even to the height of 2000 feet above the line of perpetual snow. These are the utmost limits of all vegetation, where the mean temperature seems to be $+1,{ }^{0} 1$ of Celsius (30 of Fahrenheit). The Snow Bunting, Emberiza nivalis, is the only living being that visits this elevated spot. 


\title{
I N D E X.
}

\author{
A Bo, ii. 230. \\ Acer platanoides, ii. 227. \\ Aconite, ycllow, i. 36 . \\ Aconitum lycoctonum, i. 36, 47, 138, 278. ii. 79 , \\ $123,277$. \\ Adam and Eve, i. 28. \\ Adoxa moschatellina, i. 37. \\ Agaricus, i. 151, 152, 177. ii. 158. \\ Agrostis arundinacea, ii. 228. \\ rubra, ii. 91. \\ Agues, i. 29, 180. \\ Aira alpina, ii. 279. \\ Aland, ii. 233. \\ Alca Torda, i. 64, 65. \\ Alder, hoary-leaved, i. 48, 51. ii. 277. \\ Alnus incana, ii. 277. \\ Alopecurus geniculatus, ii. 92. \\ Alps, Lapland, i. 283-322. ii. 1-81, $25 \%$. \\ Dr. Wahlenberg's observations to de- \\ termine their height, ii. 272.
}

Amanita, ii. 158. 
Amusements of the Laplanders, ii. 50-58. Anas arctica, i. 65. Andromeda carulea, i. 272. ii. 278. - hypnoides, i. 320 . ii. 280. - polifolia, i. 23, 188, 189. tetragona, ii. 28, 29, 280. Anemone Hepatica, i. 11, 32. ii. 228. - ranunculoides, i. 11. - vernalis, i. 15.

Angelica Archangelica, i. 171. ii. 60, 108, 278. Angermanland, i. 48. Animals of the alps, ii. 82, 83. Anthericum calyculatum, i. 257. Apis terrestris, i. 159. Apple-trees, i. 61. Arabis thaliana, i. 33. Aranea palustris, $\}$ i. 258 .

Arbutus alpina, ii. 278. Uva ursi, i. 7, 23, 250. Ardea cinerea, ii. 255. Arena Glarea, i. 7, 16, 32, 82, 123, 166. - molilis, i. 16.

Artemisia vulgaris, ii. 201. Arum, i. 200. Arundo Calamagrostis, ii. 90. Phragmiles, ii. 275.

Ash, i. 68 . 
Aspen, i. 77, 179.

Aspidium Filix-fomina, ii. 227.

Asplenium Trichomanes, i. 55.

Astragalus alpinus, i. $160,256,366$. ii. 2.

- leontimus, ii. 279.

- montanus, ii. 279.

Azalea lapponica, i. 299. ii. 279.

- procumbens, i. 285 . ii. 279 .

\section{B.}

Bannisteria. See Diapensia.

Bark of the aspen-tree used as food for cattle, i. 77 .

pine-tree eaten by the peasants, i. 169 .

- willow used for tanning, i. 80. birch used for tanning, i. 249 .

Barley, i. 57, 67, 73.

Bartramia fontana, i. 181-184. pomiformis, i. 13, 38.

Bartsia alpina, ii. 119.

Bears, ii. 215, 275.

Beaver, i. $88-91$.

Beech, i. 68.

Betula alla, i. 48.

- incana, i. 48 . ii. 277.

- nana, i. 19, 68, 126, 139, 186. ii. 26,50 ,

$$
278,279 .
$$

Bicornes, i. 22.

Bilberry, i. 25, 35, 208. 
Birch, common, i. $20,34,49,56,80,100,115$, 202. ii. 276.

- dwarf, i. 19, 126, 139.

Bird-traps, i. 179.

Bixa Orelana, ii. 233.

Blindness, peculiar case of, i. 217.

Boat, Lapland, i. 98.

Bog-moss, i. 139, 165, 167.

Boletus igniarius, used as a pincushion, i. 85. suaveolens, employed as a perfume, i. 151.

Bothland, East, ii. $151-166^{\circ}, 201-232$.

Bramble, strawberry-leaved, i. 51, 58, 201.

Brandy, i. 28, 122, 157. ii. 147.

Brassica oleracea, ii. 219.

Bream, i. 27.

Bryum bimum, i. 185.

$$
\text { pomiforme, i. } 13 .
$$

Buck-bean, i. 86, 200.

Buck-wheat, i. 166.

Buntings, snow, i. 71 . ii. $28 z$.

Burnet, i. 220.

Butter, i. 110.

Byssus, i. 84, 156.

- cryptarum, i. $47,55$.

- flos aquae, i. 4.

- Jolithus, i. 26. red, i. 26. 
C.

Calla palustris, i.200, 245, 350.

Callitriche autumnalis, i. 62.

Caltha palustris, i. 5, 68.

Cameraria, i. 176.

Campaniformes, i. 10.

Campanula persicifolia, ii. 226.

- serpyllifolia, i. 20, 37 .

uniflora, ii. 280.

Canis Vulpes, i. 71.

Caper, Swedish, 1. 5.

Carex, i. 5, 167.

caspitosa, ii. 225.

globularis, ii. 275 .

- panicea, ii. 98 .

- syluatica, i. 276. ii. 21, 46.

ustulata, ii. 279.

Castor, i. 88, 276. ii. 215.

Cataract of Elf-Carleby, i. 12.

Cavern at Skula-berget, i. 52.

Chaff, eaten by the peasants, i. 169 .

Chamcedaphne, i. 188.

Character of the Laplanders, i. 131, 363.

Charadrius Hinticula, i. 93, 323.

Charr, i. 128. ii. 277.

Cheese of the Laplanders, i. 102, 197.

Cherries, i. 62. 
Chrysomela graminis, i. 48 . lapponica, i. 77.

Chrysosplenium alternifolium, i. 9 .

Church tyranny, i. 157.

Church at Lulea, i. 239.

Cicindela sylvatica, i. 175.

Cicuta virosa, i. 246. ii. 136, 143.

Cinnabar, imperfect, i. 62.

Cinque-foil, purple, i. 158.

Clay, i. 31, 73.

Cloud-berry, i. 152, 203.

Club-moss, i. 20.

Coccinella trifasciata, i. 179.

Cock of the wood, i. 73, 93.

Colymbus arcticus, i. 27, 176 . ii. 98, 151.

auritus, i. 118.

Comarum palustre, i. 158.

Conferva, i. 336.

Convallaria lifolia, i. 58. ii. 274.

Cookery, i. 248; performed by the men, i. 132.

Coralloides, i. 8, 84.

Corallorrhiza, i. 223, 245. ii. $4 \pi$.

Corals, petrified, i. 30.

Cornus suecica, i. 177, 189.

Corvus Cornix, ii. 229.

- glandarius, ii. 110.

- infaustus, ii. 109, 255.

Cos molaris, i. 30.

Costmary, i. 220. 
Cotton-Rush, i. 68.

Cradles, different kinds of, i. 190.

Crake-berries, i. 138, 152. ii. 26.

Cranberries, i. 208.

Cranes, i. 94.

Cross-bills, i. 70.

Cuckoo, i. 12, 23, 62.

Cuculus canorus, i. 23, 319.

Culex pipiens, i. 159.

- pulicaris, i. 238, 251.

- reptans, i. 209, 251 . ii. 115.

Cyprcea, ii. 191.

Cyprinus Aphya, i. 102.

Brama, i. 27.

Cypripedium Calceolus, ii. 112.

D.

Daphne, i. 23.

Dermestes murinus, i. 206.

Diapensia lapponica, i. 285. ii. 280.

Dillenia. See Azalea.

Diseases of the Laplanders, ii. 32-35.

- of cattle, i. 245.

Diver, black-throated, i. 27.

Draba alpina, ii. 250.

- verna, i. 5 .

Dress, travelling, of Linnæus, i. 1.

- of the Laplanders, i. 132, 137, 326-335.

ii. $10,110,141-150$.

VOL. II. 
Dryas octopetala, ii. 280.

Ducks, wild, i. 93, 118.

Dyeing wool and leather, method of, i. 1\%0.

Dytiscus natator, i. 100.

E.

East Bothland, ii. 151-166. 201-232.

Elf-Carleby, i. 15.

Elm, common, i. 22, 68.

Elymus arenarius, ii. 204.

Emleriza Hortulanus, i. 71 . nivalis, i. 71. ii. $97,282$.

Empetrum nigrum, i. 138, 139, 152. ii. 26, 280.

Empis boreulis, i. 87, 179.

Ethemera, i. 73, 177.

Epilobium angustifolium, ii. 87.

Equisetum hyemale, i. 121.

Erica vulgaris, i. 7, 29, 25, 35, 49. ii. 119, 277.

Erigeron uniflorum, ii. 279.

Erinphorum alpinum, i. 177, 254.

polyslachion, i. 68 vaginatum, i. 68.

Erysimum Barbarea, i. 255, $267 . \beta$, i. 72.

Festivals, i. 114, 157 .

Finch, motntain, i. 23, 29.

Fir, common, i. 25, 49, 82, 202.

- spruce, i. 49, 70, 85, 187, 202.

Fisheries, i. 128, 163.

Flax, i. 200. 
Flesh-fly, i. 159.

Food of the Laplanders, i. 154.

Foxes, i. 71, 250.

Fowls, the Laplanders' method of drying, i. 79.

Fringilla Montifringilla, i. 23, 29.

Frogs, imagined to live in a woman's stomach, i. 111. Frog-spittle, i. 214.

Fucus, i. 336. ii. 263.

Fumaria bulbosa minima, i. 37.

Furniture of the mountain Lapianders, ii. 12.

\section{G. .}

Gaddewick, ferry of, mineral spring at, i. 231.

Gad-Aly, i. 215.

Gadus virens, i. 341.

Gale, sweet, i. 19.

Galium boreale, ii. 275.

Gentiuna nivalis, ii. 280.

$$
\text { tenella, ii. } 280 \text {. }
$$

Geranium sylvaticum, i. 283.

Gestrickland, i. 17. ii. 241.

Glires, i. 89.

Glirr, i. 102.

Gnats, i. 87, 159, 208, 238.

Goosander, i. 94-96.

Granite, i. 9, 30, 35.

Grayling, i. 61 .

Grebe, Jittle-eared, i. 118.

Grous, black, i. 23. 
Grous, wood, i. 179.

Grotto in the mountain of Scula, ii. 242.

Grundell, Baron, i. 70. ii. 245.

Gryllus domesticus, i. 254.

Gulls, i. 75.

Gwiniad, small, i. 161.

Gyrophorce, ii. 292.

H.

Hair-moss, great, i. 171 , 191.

Half-boots of the West Bothlanders, i. 74 .

Hare, i. 89.

Harncsi, rein-deer, i. 104.

Harr, i. 61.

Hazle, i. 62, 68.

Heart's ease, i. 41 .

Heath, i. 7, 22, 49, 56.

Hedera Helix, i. 21.

Helsingland, i. 25.

Hepatica, i. 11.

Hieracium Pilosella, i. 5.

Hippophä̈ rhamnoides, ii. 224, 233.

Hobgoblins, supposed to inhabit the mountains, i.221. Hops, 1. 36, 62.

Horns of the reindeer, i. 135.

Horselail, naked, i. 121.

Houschould œconomy of the Laplanders, i. $167-$ $172,190,197-199,340 . \quad$ ii. $5-18,23-26$, 17-50. 
Humble-bee, i. 159.

Humulus Lupulus, ii. 122, 228.

Hunting the bear, ii. $83-85$.

Huts of the Laplanders, i. 124, 155.

Hyoscyamus niger, ii. 224.

Hypunm parietinum, i. 8.

\section{I.}

Implements of husbandry, i. 65.

Insects at Bumoen, i. 200.

Lul'a, i. 233.

Pithoca, i. 216.

Umoen, i. 192-191.

Iris Pseudacorus, ii. 228.

Ivy, i. 21.

Itinerary of Linnæus, ii. 270.

J.

Jarf, i. 71.

Juncellus aquaticus, i. 122.

Juncus campestris, i. 5.

- curvalus, ii. 281.

- trifidus, i. 279.

triglumis, ii. 112.

Juniper, i. 83, 137, 156.

Jussiea. See Silbuldia.

K.

Kettle, method of boiling, i. 198. 
Kids, i. 10.

Kimi, ii. 146-151.

Korssrafi, i. 71.

Kowall, i. 111.

Lady-bird, i. 179.

Lapis mnlaris, i. 30.

Lapland Alps, i.283-322. ii. I-81, 257.

Dr. Wahlenberg's Observations to determine the height of, ii. 272.

Lapland minerals, ii. 35-37.

Norwegian, i. 322-335.

Laplanders' amusements, ii. 50-58.

character, i. 132.

dress, i. 132, 133, 137, 326-335. ii. $110_{0}$ 144-150.

diseases, ii. $32-35$.

food, i. 154.

substitute for tobacco and snuff, i. 86.

household œconomy, i. 167-172, 190,

$197-199,340,341$. ii. $5-18,23-$

$26,47-50$.

huts, i. $125-127,155$.

- marriages, ii. $67-76$.

shop, i. $119,120$.

weapons, i. 137.

Lark, i. 6. 
Larus canus, i. 75, 319.

Lathyrus palustris, ii. 226.

Ledum palustre, i. 23, 246. ii. 275.

Leontodon Taraxacum, i. 5.

Leonurus Cardiaca, ii. 224.

Lepas Balunoides, i. 336.

-Balimus, i. 336 .

Lernea asellina, i. 341.

Libellula forcipata, i. 190.

-Virgo, i. 190.

Lichen arcticus, i. 31.

- byssoides, i. 84.

- caninus, i. 31 . cocciferus, i. 84.

- ericetorum, i. 156. islandicus, i. 24 . ii 200.

-jubatus, ii. 171 .

- nivalis, i. 4, 85.

- ompha'odes, ii. 233.

- rangiferinus, i. $84,161,318$. ii. 18, 88, 109, $128,199,277$.

stygius, ii. 233.

unciulis, i. 82, 84. velleus, i. 213 .

Lichens, filamentous, i. 83, 161.

Ligusticum Levisticum, i. 73.

Lime-tree, i. 68.

Ling, i. 25, 35, 36, 82, 124, 139.

Linncea lorealis, i. 21, 37, 203, 229. 
Lilhospermum arvense, i. 5.

Lonicera Iylosteum, ii. 227.

Loxia curvirostra, i. 70.

Ludus Helmontii, i. 8.

Lulea, i. 228-255.

Iulean Lapland, i. $256-283$. ii. $81-130$.

Lumme, i. $27,176$.

Lychnis alpina, ii. 19.

$$
\text { apetala, ii. } 279 \text {. }
$$

dioica, i. 33.

Viscariu, ii. 19.

Lycksele Lapland, i. 96-194.

- parsonage, church, and school, 111. ii. 242 .

Lycopodium alpinum,

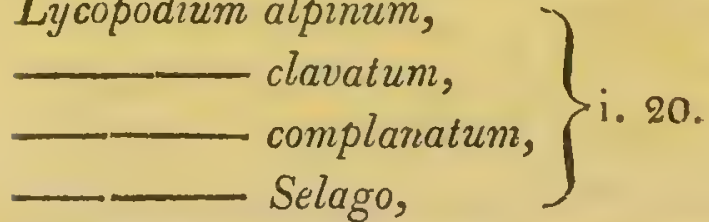

Lycopsis arvensis, i. 253.

Lysimachia thyriflora, ii. 275.

Lythrum Salicaria, ii. 164.

\section{M.}

Manners of the Laplanders, i. 131.

Maple, i. 65.

Marriages of the Laplanders, i. 113, 131, 248. ii. $67-76$.

Meal-berry, i. 250.

Medelpad, i. 35.

Medusa aurita, i. 338. 
Medusa cupillata, i. 336 . cruciala, i. 338.

Melampyrum pratense, $\}$ sylvaticum, $\}$ i. 110, 111 .

Menyanthes trifolinta, i. 86, 200, 352.

Mergus Merganser, i. 94-96.

Mesomora, i. 177, 189.

Mica, i. 26, 247.

Mice, i. 89.

Michelia. See Azalea lapponica.

Milk, i. 59, 24z-214, 273, 3i \%

- preparations of, i. 196, 242. ii. 181.

Minerals, ii. 35- 37 .

Mining, i. 195, 106.

Missne, i. 86.

Money-ivort, i. 229.

Montia fontana, i. 176.

Mosses, their fructification, i. 181-186.

Motacilla fana, i, 71.

Mountain of Skula, i.52. ii. 244.

Mures, in 89 .

Mus Lemmus, i. 102, 162, 303.

Musca carnaria, i. 159.

Muscus lichenoides, i. 213.

tec/orius, i. 85.

Mustela Gulo, i. 71. ii. 50, 279.

Mya arenaria, i. 237.

marguritifera, ii. 105.

Myosotis scorpioides, i. 5.

Myrica Gale, i. 19, 208. 
N.

Nardus stricta, i. 236.

Narthecium ossifragum, i. 257.

Norway, i. 335-366.

Norwegian Lapland, i. 322-335.

Nostoc, i. 263.

Nux vomica, i. 112.

Oak, i. 68.

Ochre, i. 62, 63.

Economy of the Torneans, ii. 173-182.

Eistrus nasalis, ii. 45.

$$
\text { Tarandi, i. } 293 \text {. ii. 2, } 23 .
$$

Oniscus aquaticus, i. 206.

Ophrys alpina, ii. 279.

$$
\text { corduta, ii. } 109 .
$$

Orchis, palmated, i. 178.

Ore, silver, i. 246.

Orolus vernus, ii. 228.

Ortolans, i. 71.

Owls, i. 93, 204.

Owl, eagle, i. 39, 41, 210.

Oxalis Acetosella, i. 11, 58, 68.

$$
\text { P. }
$$

Paris quadrifolia, i. 138.

Pedicularis, i. $252,266,366$. ii. 277.

- Alammea, i. 296. ii. 280. hirsuta, ii. 280. 
Pedicularis lapponica, ii. 278.

Perca fluvialilis, ii. 86.

Persecution, a singular instance of, i. 364.

Pes pelicani, i. 336.

Petromyzon flnviatilis, ii. 196.

Phaca alpina, ii. 275.

Phoca vitulina, ii. 234.

Phrygania bicaudata, i. 74.

Pica lapponum, i. 175.

Pikes, i. 115, 128, 162.

Pines, i. 81, 124, 131, 140.

Pinguicula, i. 197, 208, 254. ii. 109. villosa, i. 255.

Pinus Alies, i. 25, 49, 70, 187. ii. 274, 275.

nodosa, i. 214.

plicata, i. 7 .

— sylvestris, i. 25, 49. ii. 60, 66, 157, 275, 276.

Pipsten, i. 30 .

Pisum maritimum, ii. 203.

Pithoea, i. 194-228. ii. 256.

Plants at Calix, ii. 193, 195, 196.

- Flaskesele, i. 116, 117.

- Gräno, i. 174.

- Jö, ii. 202.

- Jockmock, i. 265, 266.

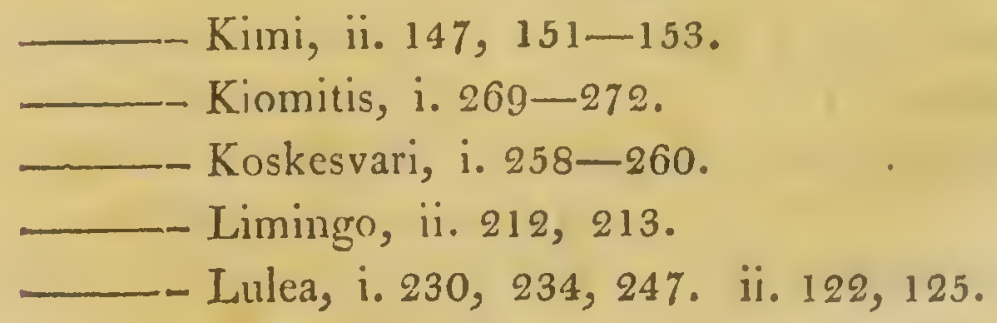


Plants at Sastmola, ii. $22 \%$.

- Skargarden, i. 220, 221.

- Torfiolme, i. 345.

Tornea, ii. 125, 131, 136-144, 169, 172.

Umoea, i. 181-186.

- Upland, i. 325.

- Wallavari, i. 283-291, 293-303.

- Wasa, ii. 223.

- Zangis, ii. 128-130.

Plants and birds near Lycksele, i. 98-100.

Plants and fishes near Pithoea, i. 222-228.

Plovers, ringed, i. 93.

Polygonum Fagopyrum, i. 166.

- viviparum, i. 282.

Polypodium, i. 55.

Polytrichum, i. 85, 191. ii. 225.

- commune, i. 124, 171.

Populus tremula, i. 77. ii. 277.

Potamogeton gramineum, ii. 112 .

- perfoliatum, ii. 92.

Potatoes, i. 62.

Poterium Sanguisorta, i. 220.

Primula, i. 5, 277.

Prunus Padus, ii. 277.

Ptarmigan, i. 35, 150.

Pteris crispa, ii. 278.

Pyrola, i. 17.

Pyrus Aucuparia, ii. 277.

Quicksand, i. 63. 
R.

Renunculus acris, i. 203.

aquatilis, ii. 91.

glacialis, ii. 281, 282.

- lapponicus, i. 156, 252.

- nivalis, ii. 281.

Redwing, i. 6, 23, 121 .

Reindcer, i. $68,79,103-110,113,127,135,161$,

$250,307-314$. ii. $22,37-46,107,110$.

method of castrating, ii. 3.

Riles alpinum, ii. 227 .

- rubrum, i. 257.

Rosa cinnamomea, ii. 274 .

Rocking children, various modes of, i. 190.

Rubus arcticus, i. 33, 52, 58, 186, 201. ii. 118, 274.

Chamcemorus, i. 152, 203, 281. ii. 109, 279.

fruticosus, ii. 118.

—-idaus, ii. 118.

saxatilis, ii. 118, 228.

Ruffs and Reeves, i. 71.

Rumex Acetosa, i. 102, 153, 315, 366. digynus, i. $253,256,366$. ii. 281 .

Rye, i. 56, 57, 67 .

S.

Salix caprea, i. 5.

- glnuca, ii. 278.

— hastatu, ii. 278.

- Helix, i. 17.

- lanata, i. 77. ii. 279.

LLapponum, ii. 26. 
Salix myrsinites, ii. 279 .

pentandra, ii. 275.

-._phylicifolia, i. 242.

- rosmarinifolia, ii. 183.

Sallow-tree, i. 55.

Salmo Allula, i. 161. ii. 86, 89, 216.

- alpinus, i. 127, 305-307. ii. 277.

- Lavaretus, i. J60. ii. 37, 97, 167, 275.

- Salar, ii. 116, 189.

- Thymallus, i. 61. ii. 275.

Salmon fishery, i. 13, 206, 344. ii. 117.

Sandpipers, i. 93.

Satyrium viride, i. 178.

Saxifraga, i. 10 . ii. 280.

Saxum fornacum, i. 30.

Scarabceus, i. 206.

Sceptrum Carolinum, i. 252, 266, 278. ii. 119, 277.

Scheuchzeria palustris, i. 257.

Schocnus Mariscus, i. 150.

Scirpus coespitosus, i. 122, 150.

- maritimus, ii. 228.

Sciurus volans, ii. 231.

$$
\text { vulgaris, ii. } 49 .
$$

Scolopax Gallinago, i. 19.

Seals, remarks on, ii. 234.

Sedum Telephium, ii. 226.

Serralula alpina, i. 259.

Shop, Laplander's, i. 119.

Sibbaldia procumbens, i. 284.

Silene acaulis, ii. 281. 
Sisymbrium Nasturtium, ii. 226.

Skelleftea, i. 203.

Skula, mountain, ii. 242.

Sledge, i. 104.

Solanum Dulcamara, ii. 224.

Solidago Virgaurea, ii. 87.

Sonchus alpinus, ii. 60, 77-79, 277.

Sorbus, ii. 277.

Spergula arvensis, i. 353.

Sphagnum, i. 37, 139, 156, 165.

- palustre, ii. 109.

Sphinx Filipendula, i. 321.

Spiders, i. 23.

Springs, mineral, i. $63,69,241,281$. ii. 231 .

Squirrels, i. 89, 176.

Stellaria minima, i. 238.

- nemorum, i. 279.

Strix Bulvo, i. 39, 210-213.

Ulula, i. 205.

Struthiopteris, ii. 277 .

Superstition of the Laplanders, i. 364 .

Summer, beauty of, in Lapland, i. 244.

Swallows, i. 71.

Swammerdamia, i. 237.

Swans, i. 94.

T.

Talc, i. 42.

Talcum Ollaris, i. 356.

Tanacetum Balsamita, i. 220. 
Tanacetum vulgare, ii. 201.

Tanning, i. 80, 249. ii. 120, 121.

Trixus baccata, i. 11.

Tents of the mountain Laplanders, ii. 7.

Tetrao Lagopus, i. 35, 150, 291, 318. ii. 258.

Tetrix, i. 23.

- Urogallus, i. 78, 177, 179. ii. 96 .

Thalictrum alpinum, i. 277.

-_- fuuvum, i. 138.

Thlaspi arvense, i. 5.

Tilia europaea, ii. 225.

Tipula juniperi, i. 21.

- rivosa, i. 186.

Toad, story of one, said to be hatched in a man's stomach, i. 112.

Tobacco, i. 62, 86.

Tofieldia palustris, i. 257, 265, 366 .

Tordmule, i. 64 .

Tormentilla officinalis, i. 155.

Tornea, ii. 130-146, 166-201.

- œconomical remarks concerning the neighbourhood of, ii. 173-182.

Traps for catching the wood grous, i. 180.

Trefoil, water, i. 86.

Tremella juniperina, i. 175.

Trientalis, i. 282. ii. 278 .

Tringa hypoleucos, i. 117.

Tringæ, i. 93. 
Turdus iliacus, i. 6, 23, 121, 176.

Tussilago frigida, ii. 277 .

nivea, ii. 275.

V.

Vaccinium Myrtillus, i. 23, 25, 35, 49, 12t, 208. ii. 275 .

- Orycoccos, i. 208.

- uliginosum, ii. 279 .

Vitis Idcea, i. 23, 124, 137, 258.

Veronica alpina, ii. 278.

- serpyllifolia, ii. 275.

Vilurnum Opulus, ii. 227.

Vicia syluatica, ii. 223.

Viola biflora, i. 139, 279. ii. 278.

- canina, i. 42.

- lactea, i. 42.

- lutea, i. 41.

- odorala, i. 5 .

- palustris, i. 20, 45 .

- tricolor, i. 5, 41 .

Violet, aquatic, i. 42.

marsh, i. 20, 45.

yellow, i. 133.

Viverra Lutreolu, ii. 231.

Ulux, i. 336.

U.

Umoea, i. 69, 178.

Upland, i. .

Upsil, i. 3. ii. 234.

VOL. II. 
Wagtail, water, i. 62.

Wahlenberg, Dr., his Observations made to determine the height of the Lapland Alps, ii. 272.

Wallavari mountain, ii. $25 \%$.

Wasp, i. 159.

Weapons, i. 137.

Well, mineral, i. 241.

West Bothland, i. 67.

Whortle-berries, i. 7, 56, 85, 124, 137.

Willows, i. 61, 68, 80, 138, 249.

Winter-green, i. 17.

Wood-sorrel, i. 11, 58, 68.

X.

Xyphias Gladius, i. 335.

Y.

Yellow-bammer, i. 71 .

Yew, i. 11 .

THE END.

\section{ERRATA.}

Vul.i. p. 134, line 11 , read set in.

206, line 3 from the boitom, for Dean read principal clcr. syman.

246, line 16, read some of the Nasaphiel silver ore.

Enmerd ly lichard Taylor and Co., Shoe-Lane, London. 


\section{Of the Publishers of this Work may le had the following Works, writlen or edited by Dr. SмrTh.}

1. Plantarum Icones inactenus inedits, plcrumquc ad Plantas in Herbario Linnæano conservatas delincatæ. Fascic. I. II. 1II. Small Folio, each containing 25 Plates, Price Three Guineas in Boards. 1789, \&c.

2. Caroli Linnar Flora Lapponica, cxlibens Plantas per Lapponiam crcscentcs, sccundun Systcma Sexuale, collectas in Itinerc Impensis Reg. Scient. Upsaliensis Anno 1732 instituto. Additis Synonymis, et Locis Natalibus omninm, Descriptionibus ct Figuris rariorum, Viribus medicatis ct œconomicis plurimarum. Editio altera, aucta et cmendata. 1792. In one Volume Octavo, with a Frontispiece and Twelve Engravings. 12s. in Boards.

3. A Sketcil of a Tour on the Contrnevt. The Second Edition. 1807. 3 Vols. 8vo. Price 1l. 7 s. in Boards.

4. Tracrs relating to Natural History, with colnurcd Plates. 8vo. 1798. 7s. Boards.

5. Flora Brtannica, Vol. 1. II. III. 8vo. 1800, \&c. 1l. 6s.6d. Boards. - The Fourth Volume of this Work will be published as specdily as possible.

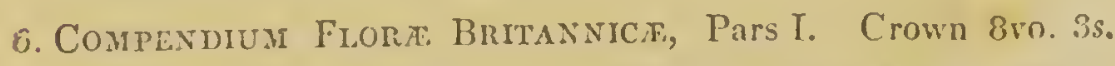
scwed.-The Conclusion of this Work will appear with that of the preceding. 


\section{Works uritten or edited by Dr. SMITH.}

7. An Introduction to Pinsiological and Systemitical BCTAYY. Second Edition. 1309. 8ro, with 14 Plates. 14s. Boards; or with the Platcs colourcel, 1/. $8 s$. in Boards.

8. A Tour to Hafod in Calidiganguine, the seat of Thomas Jonnes, Esq., M. P'.; bcantifully printed hy Bensley in Supcrroyal Fulio, and accompanicd hy Fifteex VIews (Sizc 20 Inches by $13 \frac{1}{2}$ ) engrawcd in Aquatinta, and coluurcd to imitate the original Drawings, by Jomx Surtis. Price Twolve Guincas in Boards._Only 100 Copics are printcd.

9. Flora Greca : sirc Plantarunn-rariorun Ilistoria, quas in Provinciis aut Insulis Græcie legit, investigavit, et dcpingi curavit Johaxies Sibthorp, M. D. S S. Reg. et Linu. Lond. Socius, Bot. Professor Pecgius in Academia Oxoniensi. Hic illic etiam insertæ sunt pauculæ Species quas Vir idem clarissimus, Græciam versus navigans, in ltinere, præscrtin apud Ituliam et Siciliam, iuvenerit. Charactcrcs omuium, Descriptioncs ct Sỵonyma claboravit Jaconus Edrandus Smitir, M. D. \&c. Fasciculi I. et II. Folio (forming the First Volume) with 50 bcautifully colourcd Engravings in each, Pricc Twelve Guincas cach in Boards. - Thic Third Fasciculus is in considerable Forwardness.

10. Prodronus Flore Grace, Pars I. ct II. (forming the First Volume) Royal 3ro. 10s. 6d. ench Purt in Boards.

\section{Also pullished by White and Cochrane,}

The Life of Sir Cinardes Linsaus. To which are added, a copious List of his Works, and a Biographical Sketch of the Life of lis Son, by D. 1I. SToEver. Translated from the original Gcrman by Josepi TRAPP, A. M. Handsomcly printed in Quarto, with a Portrait, Price One Guinca in Bundels. $-A$ few Copics in Inoyal Quarto, Pricc 1l. 11s. 6d. 




